\title{
A Quick Guide to Small-Molecule Inhibitors of Eukaryotic Protein Synthesis
}

\author{
S. E. Dmitriev ${ }^{1,2,3, a *}$, D. O. Vladimirov ${ }^{2}$, and K. A. Lashkevich ${ }^{1}$ \\ ${ }^{1}$ Belozersky Institute of Physico-Chemical Biology, Lomonosov Moscow State University, 119234 Moscow, Russia \\ ${ }^{2}$ Faculty of Bioengineering and Bioinformatics, Lomonosov Moscow State University, 119234 Moscow, Russia \\ ${ }^{3}$ Engelhardt Institute of Molecular Biology, Russian Academy of Sciences, 119991 Moscow, Russia \\ ${ }^{a}$ e-mail: sergey.dmitriev@belozersky.msu.ru
}

Received August 26, 2020

Revised October 4, 2020

Accepted October 4, 2020

\begin{abstract}
Eukaryotic ribosome and cap-dependent translation are attractive targets in the antitumor, antiviral, anti-inflammatory, and antiparasitic therapies. Currently, a broad array of small-molecule drugs is known that specifically inhibit protein synthesis in eukaryotic cells. Many of them are well-studied ribosome-targeting antibiotics that block translocation, the peptidyl transferase center or the polypeptide exit tunnel, modulate the binding of translation machinery components to the ribosome, and induce miscoding, premature termination or stop codon readthrough. Such inhibitors are widely used as anticancer, anthelmintic and antifungal agents in medicine, as well as fungicides in agriculture. Chemicals that affect the accuracy of stop codon recognition are promising drugs for the nonsense suppression therapy of hereditary diseases and restoration of tumor suppressor function in cancer cells. Other compounds inhibit aminoacyl-tRNA synthetases, translation factors, and components of translation-associated signaling pathways, including mTOR kinase. Some of them have antidepressant, immunosuppressive and geroprotective properties. Translation inhibitors are also used in research for gene expression analysis by ribosome profiling, as well as in cell culture techniques. In this article, we review well-studied and less known inhibitors of eukaryotic protein synthesis (with the exception of mitochondrial and plastid translation) classified by their targets and briefly describe the action mechanisms of these compounds. We also present a continuously updated database (http://eupsic.belozersky.msu.ru) that currently contains information on 370 inhibitors of eukaryotic protein synthesis.
\end{abstract}

DOI: $10.1134 / \mathrm{S} 0006297920110097$

Keywords: small-molecule drugs, 40S and 60S ribosomal subunits, 4E-BP1, eIF2 $\alpha$ phosphorylation, ribotoxic stress, cycloheximide, harringtonine, trichothecene mycotoxins, aminoglycosides, rapamycin

\section{INTRODUCTION}

Eukaryotic translation machinery has several specific features, both in the structure of its components and mechanisms of translation cycle [1-3]. Despite conservation of the functional core, eukaryotic ribosome significantly differs from the bacterial one in structural details, having much in common with the archaeal ribosome. It also contains a number of eukaryote-specific elements, including additional rRNA segments, proteins, and protein regions [2, 3]. In the course of evolution, eukaryotes have developed unique features of translation initiation,

Abbreviations: 5'-TOP, 5'-terminal oligopyrimidine tract; ARSase, aminoacyl-tRNA synthetase; DC, decoding center; GAC, GTPase-activating center; PET, ribosomal peptide tunnel; PTC, peptidyl transferase center.

* To whom correspondence should be addressed. termination, and ribosome recycling [1, 4-6]. The most prominent one is the cap-dependent ribosomal scanning, which occurs during translation initiation and involves loading of the $40 \mathrm{~S}$ ribosomal subunit near the $5^{\prime}$-end of mRNA (that usually contains the $\mathrm{m}^{7} \mathrm{G}$-cap) and its directional movement towards the 3 '-end until the start codon $[1,5]$.

The presence of both conserved and specific features explains the fact that compounds suppressing protein biosynthesis in eukaryotic cells include both universal ribosome-targeting antibiotics (active in organisms from all kingdoms of life) and eukaryote-specific inhibitors of ribosomes or other components of the translational apparatus. These compounds interact with different functional sites: the peptidyl transferase center (PTC), the E-site, the polypeptide exit tunnel (PET), or the GTPase-activating center (GAC) of the $60 \mathrm{~S}$ ribosomal subunit; the decoding center (DC) or other sites of the 40S subunit; 
the binding sites of translation factors or translationrelated proteins themselves, etc. [7-9].

Beside acting on specific targets and having different mechanisms of action, translation inhibitors may also differ in their effect on polysomes, which can be easily observed in direct experiments. Compounds that block ini- tiation, but not elongation, usually disassemble polysomes. Elongation inhibitors can either disassemble or stabilize polysomes, depending on whether they are able to act on internal ribosomes in the polysome or only on the de novo initiating ribosomes (see below). The latter statement is not obvious and often causes confusion, so some com-

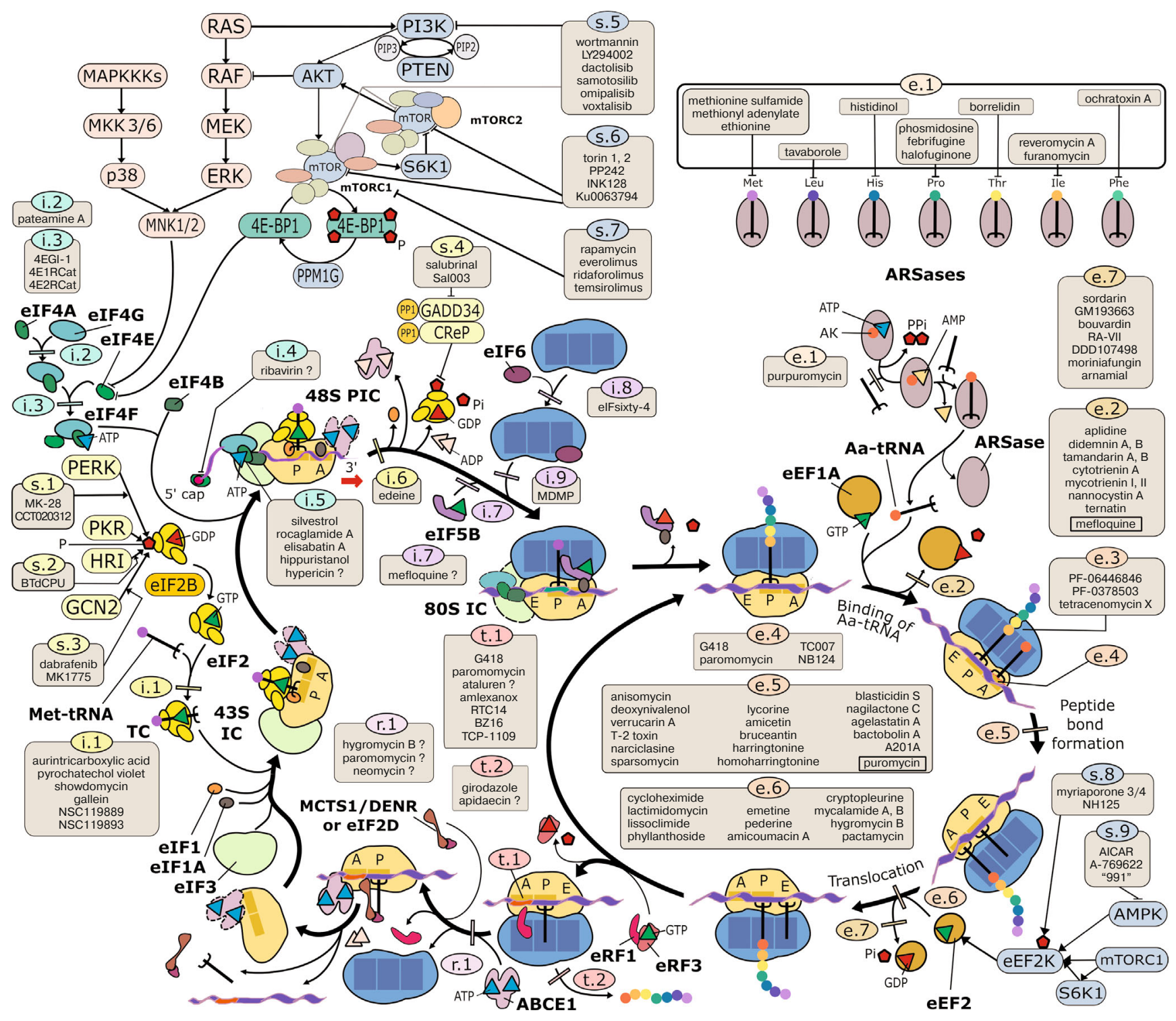

Eukaryotic translation cycle, selected regulatory pathways, and the most commonly used and well-characterized inhibitors of protein synthesis. The inhibitors are grouped according to the translation cycle stages, in which their targets are involved. Translation initiation: i.1, MettRNA $_{\mathrm{i}}$ binding to eIF2 and formation of the eIF2/Met-tRNA $/$ GTP ternary complex (TC); i.2, eIF4A binging to eIF4G; i.3, eIF4E binging to eIF4G; i.4, eIF4E binging to the $\mathrm{m}^{7} \mathrm{G}$-capped mRNA $5^{\prime}$-end; i.5, eIF4A helicase activity during eIF4F binding to the mRNA and subsequent ribosome scanning; i.6, AUG codon recognition during scanning; i.7, eIF5B interaction with the 60S subunit; i.8, eIF6 interaction with the $60 \mathrm{~S}$ subunit; i.9, $60 \mathrm{~S}$ subunit recruitment to the $48 \mathrm{~S}$ preinitiation complex (48S PIC) and formation of the $80 \mathrm{~S}$ initiation complex (80S IC). Elongation and accompanying reactions: e.1, tRNA aminoacylation; e.2, eEF1A/GDP dissociation after delivery of aminoacyl-tRNA (AatRNA); e.3, polypeptide progression in the ribosomal tunnel; e.4, tRNA accommodation/decoding; e.5, peptidyl transferase reaction (combined with the preceding stages of Aa-tRNA binding and accommodation); e.6, translocation; e.7, eEF2/GDP dissociation after translocation. Termination: t.1, stop codon recognition; t.2, peptidyl-tRNA hydrolysis. Recycling: r.1, 60S subunit dissociation. Modulators of signaling cascades: s.1-s.3, activators of eIF2 kinases; s.4, eIF2 phosphatase inhibitors; s.5, PI3K inhibitors; s.6, mTOR active site inhibitors; s.7, allosteric inhibitors of mTOR in the mTORC1 complex. Inhibitors with different mechanisms of actions affecting the same stage are shown in frames. 
pounds acting at the elongation stage (for example, harringtonine and lactimidomycin) are sometimes called initiation inhibitors in the literature. Termination inhibitors can increase the number of ribosomes in a polysome; however, compounds that cause the stop codon readthrough usually do not modify the polysome profile. The same is true for the compounds causing miscoding; they decrease the fidelity of protein synthesis, but generally do not affect the polysomes. Premature termination inducers (e.g., puromycin) disassembles polysomes. This issue is complicated by the fact that some inhibitors exhibit the concentration-dependent effects or trigger the ribotoxic or other types of stress in living cells, which might change the pattern of cell response to the inhibitor over time.

Here, we compiled a panel of small-molecule inhibitors of eukaryotic translation and listed them in the tables with minimalistic comments. The most studied inhibitors are described in detail in the text of the article (see also figure). The additional information can be found in a constantly updated database (http://eupsic.belozersky.msu.ru) at the Belozersky Institute of Physico-Chemical Biology, Moscow State University. Due to the limited space, we did not discuss inhibitors of mitochondrial and plastid translation, since ribosomes of these organelles belong to the bacterial type. We also omitted protein and peptide inhibitors of translation (such as ricin or diphtheria toxin) despite their importance and widespread usage.

\section{INHIBITORS OF EUKARYOTIC RIBOSOME}

There are several types of ribosome inhibitors common to all kingdoms of life. Most of them target conserved stages of the elongation cycle, such as ligand binding, transpeptidation, and translocation, and will be discussed in the first section of our review (Table 1). Inhibitors active toward all ribosome types will be hereafter called universal inhibitors. Otherwise, we will use the terms "eukaryote-specific" or "archaea- and eukaryote (AE)-specific". The specificity is usually determined by subtle differences in the structure of the binding site. Structural studies have shown that substitution of a single nucleotide in rRNA or a difference in one amino acid residue in a ribosomal protein might be sufficient to change ribosome configuration enough to preclude the binding of the inhibitor. Many of the inhibitors had been identified back in the 1960-70s due to the efforts of several groups of scientists, among which D. Vázquez, A. Jiménez, and S. Pestka should be specially recognized. In our review, we describe the results of studies conducted since the late 1960s, while earlier findings and the history of inhibitors that had been discovered more than half a century ago can be found in the classic reviews of the above-mentioned authors [10-13].

Ribosome-targeting elongation inhibitors. The overwhelming majority of currently known ribosome-target- ing inhibitors act at the polypeptide elongation stage. These compounds include inhibitors of peptidyl transferase reaction and translocation, peptide tunnel blockers, inducers of decoding errors (miscoding) and premature termination, as well as some other types of inhibitors with unique mechanisms of action.

Inhibitors of peptidyl transferase center. Due to its conservation, the PTC of the large ribosomal subunit is the most vulnerable spot of the "protein-synthesizing machine". In both pro- and eukaryotes, the largest number of inhibitors, although belonging to different chemical classes and interfering with the ribosome function in different ways, binds at this site (figure, e.5).

Some of these inhibitors interfere with the aminoacyl-tRNA entry or accommodation in the A-site. They include, for example, the classic AE-specific inhibitor anisomycin, which interacts with the A-site and destabilizes aminoacyl-tRNA binding [14-17]. The same site is targeted by the eukaryote-specific trichothecene mycotoxins (T-2 toxin, deoxynivalenol, verrucarin $\mathrm{A}$, and more than three dozen similar compounds with a complex four-membered heterocycle produced by parasitic fungi [14, 17-19]). The tetraheterocyclic plant alkaloids narciclasine, lycorine, haemanthamine $[14,20]$ and, presumably, their numerous derivatives, such as isonarciclasine, pseudolycorine, pretazettine [21, 22], also bind at the A-site. The same is true for harringtonine [23], an inhibitor widely used in ribosome profiling technique [24], and related homoharringtonine [14, 23, 25, 26]. Homoharringtonine in a form of a semisynthetic drug (omacetaxine mepesuccinate) is among few translation inhibitors approved by both the European Medicines Agency (EMA) and the American Food and Drug Administration (FDA) for the treatment of chronic myeloid leukemia [27]. It has also been considered as a promising drug for the antiviral therapy of COVID$19[28]$.

An interesting property of harringtonine and homoharringtonine is that they bind only to vacant $60 \mathrm{~S} / 80 \mathrm{~S}$ particles or ribosome that have just assembled from the subunits and started elongation, so the inhibitors stop elongation immediately (or soon) after the start [23]. At the same time, previously initiated ribosomes continue translation, which results in only one $80 \mathrm{~S}$ particle remaining on the mRNA at the beginning of the coding region $[25,29]$. This makes harringtonine a useful tool for mapping start codons on a genome-wide scale [24].

It should be noted that the inability to bind to actively translating polysomes is not uncommon among elongation inhibitors. When added to the cells, these compounds cause the disassembly of polysomes rather than their stabilization; therefore, they are sometimes erroneously referred to as initiation inhibitors [25, 29]. Some of the above-mentioned trichothecene mycotoxins produce a similar effect on polysomes as harringtonine. Thus, T-2 toxin, verrucarin A, nivalenol, and calonectrin 
Table 1. Small-molecule inhibitors of eukaryotic ribosome

\begin{tabular}{|c|c|c|c|c|c|c|c|}
\hline Name & $\begin{array}{l}\text { Class, group } \\
\text { of chemical } \\
\text { substances }\end{array}$ & $\begin{array}{l}\text { Specificity } \\
(B, A, E)^{\#}\end{array}$ & $\begin{array}{l}\text { Interacting } \\
\text { ribosomal } \\
\text { subunit }\end{array}$ & $\begin{array}{l}\text { Binding } \\
\text { site }^{\# \#}\end{array}$ & $\begin{array}{c}\text { Stage } \\
\text { of the } \\
\text { translation } \\
\text { cycle }^{\# \# \#}\end{array}$ & $\begin{array}{c}\text { Effect } \\
\text { on poly- } \\
\text { somes \#\#\#\# }\end{array}$ & Mechanism of action \\
\hline Anisomycin/flagecidin & $\begin{array}{l}\text { pyrrolidine, } \\
\text { anisomycin } \\
\text { group }\end{array}$ & $\mathrm{A}, \mathrm{E}$ & $60 \mathrm{~S}$ & PTC (A) & $\mathrm{E}$ & stab & PTC inhibitor \\
\hline Deacetylanisomycin & $-/ /-$ & $\mathrm{E}$ & $60 \mathrm{~S}$ & PTC (A) & $\mathrm{E}$ & stab? & $-/ /-$ \\
\hline Preussin/L-657,398 & $-/ /-$ & $\mathrm{E}$ & $60 \mathrm{~S}$ & PTC (A)? & $\mathrm{E} ?$ & & $-/ /-$ \\
\hline Calonectrin & trichothecene A & & $60 \mathrm{~S} ?$ & PTC (A)? & $\mathrm{E}$ & stab/dis & $-/ /-$ \\
\hline Neosolaniol & $-/ /-$ & $\mathrm{E}$ & $60 \mathrm{~S} ?$ & PTC (A)? & $\mathrm{E} ?$ & $?$ & $-/ /-?$ \\
\hline Scirpentriol & $-/ /-$ & $\mathrm{B}, \mathrm{A}, \mathrm{E}$ & $60 \mathrm{~S}$ & PTC (A) & $\mathrm{E}$ & dis & $-/ /-$ \\
\hline $\begin{array}{l}\text { Diacetoxyscirpenol/ } \\
\text { anguidine }\end{array}$ & $-/ /-$ & $\mathrm{B}, \mathrm{A}, \mathrm{E}$ & $60 \mathrm{~S}$ & PTC (A) & $\mathrm{E}$ & dis & $-/ /-$ \\
\hline $\mathrm{T}-2$ toxin & $-/ /-$ & $\mathrm{E}$ & $60 \mathrm{~S}$ & PTC (A) & $\mathrm{E}$ & dis & $-/ /-$ \\
\hline $\mathrm{T}-2$ triol & $-/ /-$ & $\mathrm{E}$ & $60 \mathrm{~S} ?$ & PTC (A)? & $\mathrm{E}$ ? & $?$ & $-/ /-?$ \\
\hline Trichodermin & $-/ /-$ & $\mathrm{E}$ & $60 \mathrm{~S}$ & PTC & $\mathrm{E}$ & stab/dis & $-/ /-$ \\
\hline Trichodermol & $-/ /-$ & $\mathrm{E}$ & $60 \mathrm{~S}$ & PTC & $\mathrm{E}$ & stab & $-/ /-$ \\
\hline Diacetylverrucarol & $-/ /-$ & $\mathrm{E}$ & $60 \mathrm{~S} ?$ & PTC (A)? & $\mathrm{E} ?$ & $?$ & $-/ /-?$ \\
\hline Trichothecolone & $-/ /-$ & $\mathrm{B}, \mathrm{A}, \mathrm{E}$ & $60 \mathrm{~S} ?$ & PTC (A)? & E? & stab/dis & $-/ /-?$ \\
\hline Trichothecin & trichothecene B & $\mathrm{E}$ & $60 \mathrm{~S}$ & PTC (A)? & $\mathrm{E}$ & $\mathrm{stab} / \mathrm{dis}$ & $-/ /-$ \\
\hline Fusarenone X & $-/ /-$ & $\mathrm{E}$ & $60 \mathrm{~S}$ & PTC & $\mathrm{E}$ & stab & $-/ /-$ \\
\hline $\begin{array}{l}\text { Vomitoxin/ } \\
\text { deoxynivalenol }\end{array}$ & $-/ /-$ & $\mathrm{E}$ & $60 \mathrm{~S}$ & PTC (A) & $\mathrm{E}$ & dis & $-/ /-$ \\
\hline Nivalenol & $-/ /-$ & E & $60 \mathrm{~S} ?$ & PTC (A)? & E? & dis & $-/ /-?$ \\
\hline Crotocin & trichothecene C & $\mathrm{E}$ & $60 \mathrm{~S}$ & PTC (A) & $\mathrm{E}, \mathrm{T} ?$ & stab & $-/ /-?$ \\
\hline Satratoxin G & trichothecene D & $\mathrm{E}$ & $60 \mathrm{~S}$ & PTC (A) & $\mathrm{E} ?$ & dis & $-/ /-?$ \\
\hline Roridin A & $-/ /-$ & E & $60 \mathrm{~S} ?$ & PTC (A)? & $\mathrm{E} ?$ & $?$ & $-/ /-?$ \\
\hline Myrothecin A & $-/ /-$ & E & $60 \mathrm{~S} ?$ & PTC (A)? & $\mathrm{E} ?$ & $?$ & $-/ /-?$ \\
\hline $\begin{array}{l}\text { Verrucarin A/ } \\
\text { muconomycin A }\end{array}$ & $\begin{array}{l}\text { trichothecene } \\
\mathrm{D}, \text { mucono- } \\
\text { mycin }\end{array}$ & E & $60 \mathrm{~S}$ & PTC (A) & $\mathrm{E}$ & stab & $-/ /-$ \\
\hline Muconomycin B & $-/ /-$ & $\mathrm{E}$ & $60 \mathrm{~S} ?$ & PTC (A)? & $\mathrm{E} ?$ & stab & $-/ /-$ \\
\hline Narciclasine & $\begin{array}{l}\text { tetrahetero- } \\
\text { cyclic alkaloid }\end{array}$ & $\mathrm{B}, \mathrm{A}, \mathrm{E}$ & $60 \mathrm{~S}$ & PTC (A) & $\mathrm{E}$ & stab & $-/ /-$ \\
\hline Isonarciclasine & $-/ /-$ & $\mathrm{B}, \mathrm{A}, \mathrm{E}$ & $60 \mathrm{~S} ?$ & PTC (A)? & $\mathrm{E}$ & stab & $-/ /-$ \\
\hline Lycorine & $-/ /-$ & $\mathrm{B}, \mathrm{A}, \mathrm{E}$ & $60 \mathrm{~S}$ & PTC (A) & $\mathrm{E}$ & $?$ & $-/ /-$ \\
\hline Pseudolycorine & $-/ /-$ & $\mathrm{B}, \mathrm{A}, \mathrm{E}$ & $60 \mathrm{~S}$ & PTC (A) & $\mathrm{E}$ & $?$ & $-/ /-$ \\
\hline Haemanthamine & $-/ /-$ & $\mathrm{A}, \mathrm{E}$ & $60 \mathrm{~S}$ & PTC (A) & $\mathrm{E}$ & stab & $-/ /-$ \\
\hline Haemanthidine & $-/ /-$ & $\mathrm{A}, \mathrm{E}$ & $60 \mathrm{~S}$ & PTC (A) & $\mathrm{E}$ & (stab) & $-/ /-$ \\
\hline $\begin{array}{l}\text { Bulbispermine/ } \\
\text { hamayne }\end{array}$ & $-/ /-$ & $\mathrm{E}$ & $60 \mathrm{~S}$ & PTC (A) & $\mathrm{E}$ & (stab) & $-/ /-$ \\
\hline Pretazettine & $-/ /-$ & $\mathrm{E}$ & $60 \mathrm{~S}$ & PTC (A) & $\mathrm{E}$ & stab & $-/ /-$ \\
\hline Jonquailine & $-/ /-$ & E? & $60 \mathrm{~S} ?$ & PTC (A)? & $\mathrm{E} ?$ & $?$ & $-/ /-?$ \\
\hline Crinamine & $-/ /-$ & $\mathrm{B}, \mathrm{A}, \mathrm{E}$ & $60 \mathrm{~S}$ & PTC (A) & $\mathrm{E}$ & (stab) & $-/ /-$ \\
\hline Agelastatin A & $\begin{array}{l}\text { heterocyclic } \\
\text { alkaloid }\end{array}$ & E & $60 \mathrm{~S}$ & PTC (A) & $\mathrm{E}$ & $?$ & $-/ /-$ \\
\hline
\end{tabular}


Table 1. (Contd.)

\begin{tabular}{|c|c|c|c|c|c|c|c|}
\hline Name & $\begin{array}{l}\text { Class, group } \\
\text { of chemical } \\
\text { substances }\end{array}$ & $\begin{array}{l}\text { Specificity } \\
(\mathrm{B}, \mathrm{A}, \mathrm{E})^{\#}\end{array}$ & $\begin{array}{c}\text { Interacting } \\
\text { ribosomal } \\
\text { subunit }\end{array}$ & $\begin{array}{l}\text { Binding } \\
\text { site }^{\# \#}\end{array}$ & $\begin{array}{c}\text { Stage } \\
\text { of the } \\
\text { translation } \\
\text { cycle }^{\# \# \#}\end{array}$ & $\begin{array}{l}\text { Effect } \\
\text { on poly- } \\
\text { somes }{ }^{\# \# \#}\end{array}$ & Mechanism of action \\
\hline Cephalotaxine & $\begin{array}{l}\text { heterocyclic } \\
\text { alkaloid, } \\
\text { cephalotaxine } \\
\text { group }\end{array}$ & (E) & $60 \mathrm{~S}$ & PTC (A)? & (E) & (stab) & $-/ /-$ (weak) \\
\hline Harringtonine & $-/ /-$ & $\mathrm{A}, \mathrm{E}$ & $60 \mathrm{~S}$ & PTC (A) & E & dis & $-/ /-$ \\
\hline $\begin{array}{l}\text { Homoharringtonine/ } \\
\text { omacetaxine } \\
\text { mepesuccinate }\end{array}$ & $-/ /-$ & A, E & $60 \mathrm{~S}$ & PTC (A) & $\mathrm{E}$ & dis & $-/ /-$ \\
\hline Nagilactone $\mathrm{C}$ & diterpenoid & E & $60 \mathrm{~S}$ & PTC (A) & E & dis & $-/ /-$ \\
\hline Nagilactone E & $-/ /-$ & E & $60 \mathrm{~S} ?$ & PTC (A)? & E & $?$ & $-/ /-?$ \\
\hline Bruceantin & quassinoid & $\mathrm{A}, \mathrm{E}$ & $60 \mathrm{~S}$ & PTC (A) & E & $?$ & $-/ /-$ \\
\hline Grandilactone A & $-/ /-$ & E & $60 S ?$ & PTC (A)? & E & $?$ & $-/ /-$ \\
\hline Brusatol & $-/ /-$ & E & $60 S ?$ & PTC (A) & $\mathrm{E}$ ? & $?$ & $-/ /-?$ \\
\hline Holacanthone & $-/ /-$ & $\mathrm{E}$ ? & $60 \mathrm{~S}$ & PTC (A) & $?$ & $?$ & $-/ /-$ \\
\hline Baccharinol & $-/ /-$ & $\mathrm{E}$ & $60 \mathrm{~S} ?$ & PTC (A)? & $\mathrm{E}$ ? & $?$ & $-/ /-?$ \\
\hline Ailanthinone & $-/ /-$ & E & $60 \mathrm{~S} ?$ & PTC (A)? & $\mathrm{E}$ ? & $?$ & $-/ /-?$ \\
\hline Quassin & $-/ /-$ & $\mathrm{E}$ ? & $60 \mathrm{~S} ?$ & PTC (A)? & $\mathrm{E}$ ? & $?$ & $-/ /-?$ \\
\hline Sparsomycin & $\begin{array}{l}\text { pyrimidone, } \\
\text { sparsomycin } \\
\text { group }\end{array}$ & $\mathrm{B}, \mathrm{A}, \mathrm{E}$ & $60 \mathrm{~S}$ & PTC $(\mathrm{A}, \mathrm{P})$ & $\mathrm{E}$ & stab & $-/ /-$ \\
\hline Deshydroxysparsomycin & $-/ /-$ & $\mathrm{E}$ & $60 \mathrm{~S} ?$ & PTC (A, P)? & $\mathrm{E}$ ? & $?$ & $-/ /-?$ \\
\hline Octylsparsomycin & $-/ /-$ & E & $60 \mathrm{~S} ?$ & PTC (A, P)? & $\mathrm{E}$ ? & $?$ & $-/ /-?$ \\
\hline $\begin{array}{l}\text { Phenol-alanine } \\
\text { sparsomycin }\end{array}$ & $-/ /-$ & $\mathrm{B}, \mathrm{A}, \mathrm{E}$ & $60 \mathrm{~S} ?$ & PTC (A, P)? & $\mathrm{E}$ ? & $?$ & $-/ /-?$ \\
\hline MDL 20828 & $-/ /-$ & E & $60 \mathrm{~S} ?$ & PTC (A, P)? & $\mathrm{E}$ ? & $?$ & $-/ /-?$ \\
\hline $\begin{array}{l}\text { Anthelmycin/ } \\
\text { hikizimycin }\end{array}$ & $\begin{array}{l}\text { nucleoside, } \\
\text { pyrimidone }\end{array}$ & $\mathrm{B}, \mathrm{A}, \mathrm{E}$ & $60 \mathrm{~S}$ & PTC (P) & E & (stab) & $-/ /-$ \\
\hline Blasticidin S & $\begin{array}{l}\text { nucleoside, } \\
\text { blasticidin } \\
\text { group }\end{array}$ & $\mathrm{B}, \mathrm{A}, \mathrm{E}$ & $60 \mathrm{~S}$ & PTC (P) & $\mathrm{E}$ & $?$ & $-/ /-$ \\
\hline Gougerotin & $-/ /-$ & $\mathrm{B}, \mathrm{A}, \mathrm{E}$ & $60 \mathrm{~S}$ & PTC & E & dis & $-/ /-$ \\
\hline Bagougeramine A & $-/ /-$ & $\mathrm{B}, \mathrm{A}, \mathrm{E} ?$ & $60 \mathrm{~S} ?$ & PTC? & $\mathrm{E}$ ? & $?$ & $-/ /-?$ \\
\hline Amicetin & $-/ /-$ & $\mathrm{B}, \mathrm{A}, \mathrm{E}$ & $60 \mathrm{~S}$ & PTC & E & stab & $-/ /-$ \\
\hline Bamicetin & $-/ /-$ & $\mathrm{B}, \mathrm{A}, \mathrm{E}$ & $60 \mathrm{~S}$ & PTC & E & $?$ & $-/ /-$ \\
\hline Mildiomycin & $-/ /-$ & $\mathrm{B}, \mathrm{A}, \mathrm{E}$ & $60 \mathrm{~S}$ & PTC & E & $?$ & $-/ /-$ \\
\hline Plicacetine & $-/ /-$ & $\mathrm{B}, \mathrm{A}, \mathrm{E}$ & $60 \mathrm{~S} ?$ & PTC? & $\mathrm{E}$ ? & $?$ & $-/ /-($ weak $)$ \\
\hline Arginomycin & $-/ /-$ & $\mathrm{B}, \mathrm{A}, \mathrm{E}$ & $60 \mathrm{~S} ?$ & PTC? & $\mathrm{E}$ ? & $?$ & $-/ /-?$ \\
\hline Puromycin & $\begin{array}{l}\text { aminoacyl- } \\
\text { nucleoside }\end{array}$ & $\mathrm{B}, \mathrm{A}, \mathrm{E}$ & $60 \mathrm{~S}$ & A & E & dis & $\begin{array}{l}\text { indices premature } \\
\text { termination }\end{array}$ \\
\hline A201A & $-/ /-$ & $\mathrm{B}, \mathrm{A}, \mathrm{E}$ & $60 \mathrm{~S}$ & A & E & & PTC inhibitor \\
\hline Bactobolin & isocoumarin & $\mathrm{B}, \mathrm{A}, \mathrm{E} ?$ & $60 \mathrm{~S}$ & PTC (P) & $\mathrm{E}$ & $?$ & $-/ /-$ \\
\hline Actinobolin & $-/ /-$ & $\mathrm{B}, \mathrm{A}, \mathrm{E}$ & $60 \mathrm{~S}$ & PTC & E & $?$ & $-/ /-$ \\
\hline Amicoumacin A & $-/ /-$ & $\mathrm{B}, \mathrm{A}, \mathrm{E}$ & $40 \mathrm{~S}$ & E-site & E & $?$ & translocation inhibitor \\
\hline Baciphelacin & $-/ /-$ & $\mathrm{B}, \mathrm{A}, \mathrm{E}$ & $?$ & $?$ & $\mathrm{I} ?$ & $?$ & $?$ \\
\hline
\end{tabular}


Table 1. (Contd.)

\begin{tabular}{|c|c|c|c|c|c|c|c|}
\hline Name & $\begin{array}{l}\text { Class, group } \\
\text { of chemical } \\
\text { substances }\end{array}$ & $\begin{array}{l}\text { Specificity } \\
(\mathrm{B}, \mathrm{A}, \mathrm{E})^{\#}\end{array}$ & $\begin{array}{c}\text { Interacting } \\
\text { ribosomal } \\
\text { subunit }\end{array}$ & $\begin{array}{l}\text { Binding } \\
\text { site }^{\# \#}\end{array}$ & $\begin{array}{c}\text { Stage } \\
\text { of the } \\
\text { translation } \\
\text { cycle }^{\# \# \#}\end{array}$ & $\begin{array}{l}\text { Effect } \\
\text { on poly- } \\
\text { somes }{ }^{\# \# \#}\end{array}$ & Mechanism of action \\
\hline Oosponol & $-/ /-$ & $\mathrm{B}, \mathrm{A}, \mathrm{E} ?$ & $?$ & $?$ & $?$ & $?$ & $?$ \\
\hline AHR-1911 & $\begin{array}{l}\text { thiopseudo- } \\
\text { urea }\end{array}$ & $\mathrm{B}, \mathrm{A}, \mathrm{E}$ & $60 \mathrm{~S} ?$ & PTC? & E & & PTC inhibitor \\
\hline Tenuazonic acid & pyrroline & $\mathrm{E}$ & $60 \mathrm{~S} ?$ & PTC (A, P) & $?$ & stab & $-/ /-$ \\
\hline Bottromycin A2 & cyclic peptide & $\mathrm{B}, \mathrm{A}, \mathrm{E} ?$ & $60 \mathrm{~S} ?$ & PTC? & $\mathrm{E}$ ? & stab? & $-/ /-?$ \\
\hline Griseoviridin & $\begin{array}{l}\text { cyclodepsi- } \\
\text { peptide }\end{array}$ & $\mathrm{B}, \mathrm{A}, \mathrm{E}$ & $60 \mathrm{~S}$ & PTC & $\mathrm{E}$ & $?$ & $-/ /-?$ \\
\hline Cyclopiazonic acid & $\begin{array}{l}\text { ergoline } \\
\text { alkaloid }\end{array}$ & $\mathrm{B}, \mathrm{A}, \mathrm{E}$ & $60 \mathrm{~S} ?$ & $?$ & $\mathrm{E}$ & $?$ & $-/ /-?$ \\
\hline PF-06446846/PF846 & & $\mathrm{B}, \mathrm{A}, \mathrm{E}$ & $60 \mathrm{~S}$ & PET & E & $?$ & $\begin{array}{l}\text { alters path of nascent } \\
\text { peptide, blocks translo- } \\
\text { cation }\end{array}$ \\
\hline PF-06378503/PF8503 & & $\mathrm{E}$ & $60 \mathrm{~S} ?$ & PET? & $\mathrm{E}$ & $?$ & $-/ /-?$ \\
\hline Tetracenomycin X & $\begin{array}{l}\text { aromatic } \\
\text { polyketide, } \\
\text { tetraceno- } \\
\text { mycin group }\end{array}$ & $\mathrm{B}, \mathrm{A}, \mathrm{E}$ & $60 \mathrm{~S}$ & PET & $\mathrm{E}$ ? & $?$ & $\begin{array}{l}\text { blocks PET, hinder } \\
\text { peptide progression }\end{array}$ \\
\hline Tetracycline Col-3 & $\begin{array}{l}\text { aromatic } \\
\text { polyketide, } \\
\text { tetracycline } \\
\text { group }\end{array}$ & $\mathrm{B}, \mathrm{A}, \mathrm{E}$ & $40 \mathrm{~S}, 60 \mathrm{~S}$ & $\begin{array}{l}\text { PET and } \\
\text { other }\end{array}$ & $\mathrm{E}$ ? & $?$ & $?$ \\
\hline Doxycycline & $-/ /-$ & $\mathrm{B}, \mathrm{A}, \mathrm{E}$ & $40 \mathrm{~S}, 60 \mathrm{~S}$ & $\begin{array}{l}\text { PET and } \\
\text { other }\end{array}$ & $\mathrm{E}$ ? & $?$ & $?$ \\
\hline Tigecycline & $-/ /-$ & $\mathrm{B}, \mathrm{A}, \mathrm{E}$ & 40S? 60S? & $?$ & $\mathrm{E}$ & $?$ & $\begin{array}{l}\text { inhibits Aa-tRNA } \\
\text { binding? }\end{array}$ \\
\hline Minocycline & $-/ /-$ & $\mathrm{B}, \mathrm{A}, \mathrm{E}$ & 40S? 60S? & $?$ & $\mathrm{E}$ ? & $?$ & $?$ \\
\hline Doxorubicin & $\begin{array}{l}\text { aromatic } \\
\text { polyketide, } \\
\text { anthracycline } \\
\text { group }\end{array}$ & $\mathrm{E}$ ? & $?$ & $?$ & $\mathrm{~T}$ & $?$ & $\begin{array}{l}\text { promotes stop-codon } \\
\text { readthrough }\end{array}$ \\
\hline $\begin{array}{l}\text { Cycloheximide/ } \\
\text { naramycin A/actidion }\end{array}$ & glutarimide & $\mathrm{E}$ & $60 \mathrm{~S}$ & E-site & $\mathrm{E}$ & stab & translocation inhibitor \\
\hline Naramycin B & $-/ /-$ & $\mathrm{E}$ & $60 \mathrm{~S} ?$ & E-site? & $?$ & $?$ & $-/ /-?$ \\
\hline Acetoxycycloheximide & $-/ /-$ & $\mathrm{E}$ & $60 \mathrm{~S}$ & E-site? & E & stab & $-/ /-?$ \\
\hline Streptimidone & $-/ /-$ & $\mathrm{E}$ & $60 \mathrm{~S}$ & E-site? & $\mathrm{E}$ & $?$ & $-/ /-?$ \\
\hline Streptovitacin A & $-/ /-$ & $\mathrm{E}$ & $60 \mathrm{~S}$ & E-site? & $\mathrm{E}$ ? & stab & $-/ /-?$ \\
\hline Actiphenol & $-/ /-$ & E & $60 \mathrm{~S} ?$ & E-site? & $\mathrm{E}$ ? & $?$ & $-/ /-?$ \\
\hline Lactimidomycin & $-/ /-$ & $\mathrm{E}$ & $60 \mathrm{~S}$ & E-site & $\mathrm{E}$ & dis & $-/ /-$ \\
\hline Isomigrastatin & $-/ /-$ & $\mathrm{E}$ & $60 \mathrm{~S} ?$ & E-site? & $\mathrm{E}$ ? & $?$ & $-/ /-?$ \\
\hline ECA-LTM & $-/ /-$ & $\mathrm{E}$ & $60 \mathrm{~S} ?$ & E-site? & $\mathrm{E}$ ? & $?$ & $-/ /-?$ \\
\hline Streptoglutarimide H & $-/ /-$ & $\mathrm{B}, \mathrm{A}, \mathrm{E}$ & $60 \mathrm{~S} ?$ & E-site? & $\mathrm{E}$ ? & $?$ & $-/ /-?$ \\
\hline Chlorolissoclimide & $\begin{array}{l}\text { labdane diter- } \\
\text { penoid, lisso- } \\
\text { climide group }\end{array}$ & E & $60 \mathrm{~S}$ & E-site & E & stab & $-/ /-$ \\
\hline Lissoclimide C45 & $-/ /-$ & $\mathrm{E}$ & $60 \mathrm{~S}$ & E-site & $\mathrm{E}$ & stab & $-/ /-?$ \\
\hline Haterumaimides $\mathrm{Q}$ & $-/ /-$ & $\mathrm{E}$ & $60 \mathrm{~S} ?$ & E-site? & E & stab & $-/ /-$ \\
\hline Phyllanthoside & glycoside & $\mathrm{E}$ & $60 \mathrm{~S}$ & E-site & $\mathrm{E}$ & dis & $-/ /-$ \\
\hline
\end{tabular}


Table 1. (Contd.)

\begin{tabular}{|c|c|c|c|c|c|c|c|}
\hline Name & $\begin{array}{l}\text { Class, group } \\
\text { of chemical } \\
\text { substances }\end{array}$ & $\begin{array}{l}\text { Specificity } \\
(\mathrm{B}, \mathrm{A}, \mathrm{E})^{\#}\end{array}$ & $\begin{array}{l}\text { Interacting } \\
\text { ribosomal } \\
\text { subunit }\end{array}$ & $\begin{array}{l}\text { Binding } \\
\text { site }^{\# \#}\end{array}$ & $\begin{array}{c}\text { Stage } \\
\text { of the } \\
\text { translation } \\
\text { cycle }^{\# \# \#}\end{array}$ & $\begin{array}{c}\text { Effect } \\
\text { on poly- } \\
\text { somes } \# \# \#\end{array}$ & Mechanism of action \\
\hline $\begin{array}{l}\text { S3'-desacetyl } \\
\text { phyllanthoside }\end{array}$ & $-/ /-$ & $\mathrm{E}$ & $60 \mathrm{~S} ?$ & E-site? & $?$ & $?$ & $-/ /-?$ \\
\hline Pederin & $\begin{array}{l}\text { polyketide, } \\
\text { pederin group }\end{array}$ & E & 60 & E-site & E & stab & $-/ /-$ \\
\hline $\begin{array}{l}\text { Psymberin/ } \\
\text { irciniastatin A }\end{array}$ & $-/ /-$ & E & $60 \mathrm{~S}$ & E-site & $\mathrm{E}$ & $?$ & $-/ /-$ \\
\hline Theopederin B & $-/ /-$ & $\mathrm{A}, \mathrm{E}$ & $60 \mathrm{~S}$ & E-site & $\mathrm{E}$ & $?$ & $-/ /-$ \\
\hline Mycalamide B & $-/ /-$ & $\mathrm{B}, \mathrm{A}, \mathrm{E}$ & $60 \mathrm{~S}$ & E-site & E & dis & $-/ /-$ \\
\hline Onnamide A & $-/ /-$ & A? E & $60 \mathrm{~S}$ & E-site & $\mathrm{E}$ & $?$ & $-/ /-$ \\
\hline Tedanolide & $\begin{array}{l}\text { polyketide, } \\
\text { tedanolide } \\
\text { group }\end{array}$ & A? E & $60 \mathrm{~S}$ & E-site & E & $?$ & $-/ /-$ \\
\hline 13-deoxytedanolide & $-/ /-$ & A, E & $60 \mathrm{~S}$ & E-site & $\mathrm{E}$ & $?$ & $-/ /-$ \\
\hline Myriaporone 3/4 & $-/ /-$ & $\mathrm{A}, \mathrm{E}$ & eEF2? & - & E & $?$ & (see Table 3) \\
\hline Emetine & $\begin{array}{l}\text { pyridoiso- } \\
\text { quinoline } \\
\text { alkaloid, eme- } \\
\text { tine group }\end{array}$ & $\mathrm{E}$ & $40 \mathrm{~S}$ & E-site & $\mathrm{E}$ & stab & translocation inhibitor \\
\hline Dehydroemetine & $-/ /-$ & $\mathrm{E}$ & $40 S ?$ & E-site? & $\mathrm{E}$ ? & (stab) & $-/ /-$ \\
\hline Cephaeline & $-/ /-$ & E & $40 S ?$ & E-site? & $\mathrm{E}$ ? & (stab) & $-/ /-$ \\
\hline Cryptopleurine & $\begin{array}{l}\text { phenanthro- } \\
\text { quinolizidine } \\
\text { alkaloid, eme- } \\
\text { tine-like }\end{array}$ & $\mathrm{E}$ & 40S, 60S? & E-site & E & $?$ & $-/ /-$ \\
\hline Tylocrebrine & $-/ /-$ & $\mathrm{B}$ ? E & $40 \mathrm{~S} ?$ & E-site? & E & $?$ & $-/ /-$ \\
\hline Tubulosine & $-/ /-$ & $\mathrm{E}$ & 40S, 60S? & E-site? & E & $?$ & $-/ /-$ \\
\hline Tylophorine/DCB-3500 & $-/ /-$ & B?, A, E & $40 \mathrm{~S}$ & E-site? & $\mathrm{E}$ & stab & $-/ /-$ \\
\hline Rac-cryptopleurin & $-/ /-$ & E & $40 S ?$ & E-site? & $\mathrm{E}$ & $?$ & $-/ /-$ \\
\hline YXM-110 & $-/ /-$ & E & $40 \mathrm{~S} ?$ & E-site? & E & $?$ & $-/ /-$ \\
\hline Pactamycin & $\begin{array}{l}\text { aminocy- } \\
\text { clopentitol, } \\
\text { pactamycin } \\
\text { group }\end{array}$ & $\mathrm{B}, \mathrm{A}, \mathrm{E}$ & $40 \mathrm{~S}$ & E-site & E (I?) & (dis) & $-/ /-$ \\
\hline de-6-MSA-pactamycin & $-/ /-$ & $\mathrm{B}, \mathrm{A}, \mathrm{E}$ & $40 \mathrm{~S} ?$ & E-site? & E (I?) & $?$ & $-/ /-?$ \\
\hline Zaluzanin C & $\begin{array}{l}\text { sesquiterpene } \\
\text { lactone }\end{array}$ & $\mathrm{E}$ & $?$ & $?$ & $\mathrm{E}$ & $?$ & $-/ /-$ \\
\hline Hygromycin B & $\begin{array}{l}\text { 2-DOS } \\
\text { aminoglyco- } \\
\text { side, non- } \\
\text { canonical }\end{array}$ & $\mathrm{B}, \mathrm{A}, \mathrm{E}$ & $40 \mathrm{~S} ?$ & DC & $\mathrm{E}(\mathrm{R} ?)$ & stab & $-/ /-$ \\
\hline G418/geneticin & $\begin{array}{l}\text { 2-DOS } \\
\text { aminoglyco- } \\
\text { side, 4,6-dis- } \\
\text { ubstituted }\end{array}$ & $\mathrm{B}, \mathrm{E}$ & $40 \mathrm{~S}, 60 \mathrm{~S}$ & DC, PET & $\mathrm{E}, \mathrm{T}$ & dis & $\begin{array}{l}\text { induces miscoding, } \\
\text { promotes stop-codon } \\
\text { readthrough (HC } \\
\text { inhibits translocation) }\end{array}$ \\
\hline Gentamicins & $-/ /-$ & B, E & $40 \mathrm{~S}, 60 \mathrm{~S}$ & DC, PET & $\mathrm{E}, \mathrm{T}$ & dis & $-/ /-$ \\
\hline Tobramycin & $-/ /-$ & $\mathrm{B}, \mathrm{E} ?$ & 40S, 60S? & $\mathrm{DC}$ & E, T & dis? & $-/ /-$ \\
\hline Amikacin & $-/ /-$ & B, E & $40 \mathrm{~S}$ & $\mathrm{DC}$ & E, T & dis & $-/ /-$ \\
\hline Netilmicin & $-/ /-$ & $\mathrm{B}, \mathrm{A}, \mathrm{E} ?$ & $40 \mathrm{~S} ?$ & $\mathrm{DC} ?$ & $\mathrm{E}$ ? & dis? & $-/ /-$ \\
\hline
\end{tabular}


Table 1. (Contd.)

\begin{tabular}{|c|c|c|c|c|c|c|c|}
\hline Name & $\begin{array}{l}\text { Class, group } \\
\text { of chemical } \\
\text { substances }\end{array}$ & $\begin{array}{l}\text { Specificity } \\
(\mathrm{B}, \mathrm{A}, \mathrm{E})^{\#}\end{array}$ & $\begin{array}{l}\text { Interacting } \\
\text { ribosomal } \\
\text { subunit }\end{array}$ & $\begin{array}{l}\text { Binding } \\
\text { site }^{\# \#}\end{array}$ & $\begin{array}{c}\text { Stage } \\
\text { of the } \\
\text { translation } \\
\text { cycle }^{\# \# \#}\end{array}$ & $\begin{array}{l}\text { Effect } \\
\text { on poly- } \\
\text { somes } \# \# \#\end{array}$ & Mechanism of action \\
\hline Paromomycin & $\begin{array}{l}\text { 2-DOS amino- } \\
\text { glycoside, } 4,5- \\
\text { disubstituted }\end{array}$ & $\mathrm{B}, \mathrm{E}$ & $40 \mathrm{~S}, 60 \mathrm{~S}$ & DC & E, T (R?) & dis & $-/ /-$ \\
\hline Lividomycin & $-/ /-$ & $\mathrm{B}, \mathrm{A}, \mathrm{E} ?$ & $40 \mathrm{~S} ?$ & DC? & E & $?$ & $-/ /-$ \\
\hline Neomycin & $-/ /-$ & $\mathrm{B}, \mathrm{A}, \mathrm{E} ?$ & $40 \mathrm{~S} ?$ & $\mathrm{DC} ?$ & E, T (R?) & $?$ & $-/ /-$ \\
\hline TC007 & $-/ /-$ & $\mathrm{B}, \mathrm{A}, \mathrm{E}$ & $40 \mathrm{~S}, 60 \mathrm{~S}$ & DC, PET & $\mathrm{T}$ & $?$ & $-/ /-$ \\
\hline NB74 & $-/ /-$ & $\mathrm{B}$ ? E & $40 \mathrm{~S}$ & DC & $\mathrm{E}, \mathrm{T}$ & $?$ & $-/ /-$ \\
\hline NB124 & $-/ /-$ & $\mathrm{B}$ ? E & $40 \mathrm{~S}$ & DC? & E, T & $?$ & $-/ /-$ \\
\hline NB156 & $\begin{array}{l}-/ /-, \mathrm{NB} 74 \\
\text { derivative }\end{array}$ & B?, E & $40 \mathrm{~S}$ & $\mathrm{DC}$ & E, T & $?$ & $-/ /-$ \\
\hline NB157 & $\begin{array}{l}-/ /-, \text { NB124 } \\
\text { derivative }\end{array}$ & B?, E & $40 \mathrm{~S}$ & DC & $\mathrm{E}, \mathrm{T}$ & $?$ & $-/ /-$ \\
\hline Neamine & $\begin{array}{l}\text { 2-DOS } \\
\text { aminoglyco- } \\
\text { side, 4-mono- } \\
\text { substituted }\end{array}$ & $\mathrm{B}, \mathrm{E}$ & $60 \mathrm{~S} ?$ & DC & $\mathrm{E}, \mathrm{T}$ & dis? & $-/ /-$ \\
\hline Apramycin & $-/ /-$ & $\mathrm{B}, \mathrm{E}$ & $40 \mathrm{~S} ?$ & DC & E & $?$ & $-/ /-?$ \\
\hline Negamycin & $\begin{array}{l}\text { negamycin } \\
\text { group }\end{array}$ & $\mathrm{B}, \mathrm{A}, \mathrm{E}$ & $40 \mathrm{~S}$ & $?$ & $\mathrm{~T}$ & stab & $-/ /-$ \\
\hline 3-Epi-deoxynegamycin & $-/ /-$ & E & $?$ & $?$ & $\mathrm{~T}$ & $?$ & $-/ /-?$ \\
\hline ТCР-1109 & $-/ /-$ & $\mathrm{E}$ & $40 \mathrm{~S}$ & & $\mathrm{~T}$ & $?$ & $-/ /-$ \\
\hline Ataluren/PTC124 & oxadiazoles & $\mathrm{E}$ & $60 \mathrm{~S} ?$ & $\mathrm{~A} ?$ & $\mathrm{~T} ?$ & $?$ & $-/ /-?$ \\
\hline Amlexanox & benzopyrans & E & $?$ & & $\mathrm{~T}$ & & $-/ /-$ \\
\hline RTC204 & & $\mathrm{E}$ & $?$ & $?$ & $\mathrm{~T}$ & $?$ & $-/ /-$ \\
\hline RTC219 & & $\mathrm{E}$ & $?$ & $?$ & $\mathrm{~T}$ & $?$ & $-/ /-$ \\
\hline GJ071 & & E & $?$ & $?$ & $\mathrm{~T}$ & $?$ & $-/ /-$ \\
\hline GJ072 & & E & $?$ & $?$ & $\mathrm{~T}$ & $?$ & $-/ /-$ \\
\hline GJ103 & & $\mathrm{E}$ & $?$ & $?$ & $\mathrm{~T}$ & $?$ & $-/ /-$ \\
\hline RTC13 & $\begin{array}{l}\text { thiazolidinone } \\
\text { group }\end{array}$ & E & $40 S ?$ & $?$ & $\mathrm{~T}$ & $?$ & $-/ /-$ \\
\hline RTC14 & $-/ /-$ & E & $?$ & $?$ & $\mathrm{~T}$ & $?$ & $-/ /-$ \\
\hline BZ6 & $-/ /-$ & $\mathrm{E}$ & $?$ & $?$ & $\mathrm{~T}$ & $?$ & $-/ /-$ \\
\hline BZ16 & $-/ /-$ & E & $?$ & $?$ & $\mathrm{~T}$ & $?$ & $-/ /-$ \\
\hline CDX5-1 & phthalimide & $?$ & $?$ & $?$ & $?$ & $?$ & $\begin{array}{l}\text { enhances induction of } \\
\text { stop-codon readthrough } \\
\text { by aminoglycosides }\end{array}$ \\
\hline $\begin{array}{l}\mathrm{RP} 49532 \mathrm{~A} / \text { girodazole/ } \\
\text { girolline }\end{array}$ & & $\mathrm{A}, \mathrm{E}$ & $60 \mathrm{~S}$ & E-site & $\mathrm{T}$ & $?$ & inhibits peptide release \\
\hline Sanguinamide B & cyclic peptide & $\mathrm{B}, \mathrm{A}, \mathrm{E}$ & $40 \mathrm{~S}, 60 \mathrm{~S}$ & $\begin{array}{l}\text { uS17, uL3, } \\
\text { uL30, other }\end{array}$ & $?$ & $?$ & $?$ \\
\hline Daptomycin & $\begin{array}{l}\text { cyclic lipo- } \\
\text { peptide }\end{array}$ & $\mathrm{B}, \mathrm{A} ?, \mathrm{E}$ & $40 \mathrm{~S}$ & eS19 & $?$ & $?$ & $?$ \\
\hline QL-XII-47/QL47 & QL47 group & E & $?$ & $?$ & $\mathrm{E}$ ? & $?$ & $?$ \\
\hline YKL-04-085 & $-/ /-$ & E & $?$ & $?$ & $\mathrm{E}$ ? & $?$ & $?$ \\
\hline Mefloquine & quinoline & $\mathrm{E}^{*}$ & $60 \mathrm{~S}$ & GAC & E & $?$ & $\begin{array}{l}\text { impedes accommodation } \\
\text { of eEF1A, eEF2 (eIF5B?) }\end{array}$ \\
\hline
\end{tabular}


Table 1. (Contd.)

\begin{tabular}{|c|c|c|c|c|c|c|c|}
\hline Name & $\begin{array}{l}\text { Class, group } \\
\text { of chemical } \\
\text { substances }\end{array}$ & $\begin{array}{l}\text { Specificity } \\
(B, A, E)^{\#}\end{array}$ & $\begin{array}{c}\text { Interacting } \\
\text { ribosomal } \\
\text { subunit }\end{array}$ & $\begin{array}{l}\text { Binding } \\
\text { site }^{\# \#}\end{array}$ & $\begin{array}{c}\text { Stage } \\
\text { of the } \\
\text { translation } \\
\text { cycle }^{\# \# \#}\end{array}$ & $\begin{array}{c}\text { Effect } \\
\text { on poly- } \\
\text { somes } \# \# \#\end{array}$ & Mechanism of action \\
\hline Edeine A & & $\mathrm{B}, \mathrm{A}, \mathrm{E}$ & $40 \mathrm{~S}$ & E-site & I & $?$ & $\begin{array}{l}\text { affects binding } \\
\text { or accommodation } \\
\text { of Met-tRNAi }\end{array}$ \\
\hline MDMP & & $\mathrm{E}$ & 40S? 60S? & $?$ & I & dis & prevents $60 \mathrm{~S}$ joining \\
\hline eIFsixty-4 & & $\mathrm{E}$ & $60 \mathrm{~S}$ & $?$ & I & dis & $\begin{array}{l}\text { precludes eIF6 binding } \\
\text { to } 60 \mathrm{~S}\end{array}$ \\
\hline
\end{tabular}

Notes: ${ }^{\#} \mathrm{~B}$, bacteria; A, archaea; E, eukaryotes. * Denotes a narrower group of organisms (for example, fungi or protozoa).

\#\# PTC (A), A-site of the PTC; PTC (P), P-site of the PTC; other abbreviation as in the main text.

\#\# I, initiation; E, elongation; T, termination; R, recycling.

\#\#\# stab, stabilizes polysomes; dis, disassembles polysomes, stab/dis, stabilizes or disassembles polysomes depending on the concentration or other conditions.

"?" means "presumably" (by analogy with a chemically similar compound, based on the information from other organisms or on controversial data); brackets, phenomenon is less pronounced than in other cases; $\mathrm{HC}$, at high concentration.

disassemble polysomes, while trichothecin, trichodermin, and scirpentriol, although have the same trichothecene core, stabilize them [19, 30, 31]. The difference in the action was explained by the particular side radicals in the certain positions of the scaffold [19, 30, 32]. In the case of some mycotoxins, the effect may also depend on the drug concentration. For example, diacetoxyscirpenol and fusarenone $\mathrm{X}$, which normally disassemble polysomes, stabilize them when used at a 100 times higher concentration $[30,33]$. The ability to bind to the ribosomes with the vacant A-site only and to disassemble polysomes is also typical for some translocation inhibitors, e.g., lactimidomycin [34] (the only case when a mechanism of this phenomenon has been explored, see the text below for the proposed explanation).

The A-site of the PTC is also targeted by other chemicals, whose structure is principally different from the structure of the above inhibitors. They are natural compounds nagilactone $\mathrm{C}[14,35]$ and agelastatin A [36], as well as bruceantin (a member of a wide class of quassinoids, which includes many potential anticancer drugs) [26, 37, 38]. Nagilactone E, which has been recently studied using the systems biology approach, also inhibits elongation, likely by the same mechanism [39]. The accommodation of aminoacyl-tRNA in the A-site is impeded by the universal antibiotic A201A, which has a nucleoside-like region resembling the CCA-end of tRNA [13, 40].

Some compounds bind to the P-site of the PTC. Among those are two universal inhibitors of the peptidyl transferase reaction - bactobolin A (isocoumarin derivative) [41, 42] and blasticidin S (nucleoside antibiotic) [14, $17,43,44]$. Interestingly, in bacteria, blasticidin S primarily inhibits translation termination rather than elongation [45], but in eukaryotes, its effect on termination is negligible [46]. A number of insufficiently studied blasti- cidin-like nucleoside antibiotics, such as anthelmycin (hikizimycin), gougerotin, amicetin, bamicetin, and others [47-49], also weaken aminoacyl-tRNA binding and prevent transpeptidation [43].

Another nucleoside analog interacting with the PTC and affecting ligand binding and accommodation is sparsomycin [17, 18]. The structure of its complex with the eukaryotic ribosome is not yet available, but its interaction with the large ribosomal subunit of archaea has been studied [44]. Based on these structural data, it was suggested that sparsomycin forms multiple contacts with the CCA-end of tRNA in the P-site, while simultaneously preventing the binding of aminoacyl-tRNA to the A-site.

It should be noted that because of the lack of structural and functional data, it is often impossible to unambiguously determine whether the mechanism of action of a particular PTC inhibitor is associated with impaired binding or accommodation of ligands or with conformational rearrangements of the PTC itself (resulting in ineffective catalysis). Therefore, it is uncommon to classify PTC inhibitors further based on a particular stage they block. The situation is further complicated by the recently discovered amino acid specificity of PTC inhibitors. For example, structural data suggest that harringtonine and its derivatives, as well as trichothecene mycotoxins, interfere with the aminoacyl-tRNA entry or at least with the aminoacyl residue accommodation in the A-site $[14,26]$. However, the data of the toeprinting assay and ribosome profiling suggest [50-52] that these compounds allow a few elongation cycles to be successfully performed before the ribosome stops at a certain position, which is determined by the amino acid residue at the $\mathrm{C}$-terminus of the peptidyl moiety of the P-site ligand. It remains unclear how the ribosome can synthesize a polypeptide fragment several amino acids long, while its PTC is occupied by a large antibiotic molecule, and why some amino 
acids can be incorporated successfully, yet the synthesis is blocked on others. The amino acid specificity of PTC inhibitors was first documented in 2013 for harringtonine [50]; it has been shown by the toeprinting technique that this drug arrests the translating ribosome only when the last amino acid attached to the P-site tRNA is lysine, arginine, or tyrosine. Later, the tolerance to the incorporation of certain amino acids into the growing peptide and sensitivity to the others was revealed for many classic PTC inhibitors, including anisomycin, sparsomycin, blasticidin S, and a number of trichothecene mycotoxins [51]. The same phenomenon was observed for some antibiotics blocking the PTC of the bacterial ribosome [53]. However, in the latter case, the specificity was determined by the amino acid residue preceding the one located in the P-site: translation was stopped mainly by alanine (and to a lesser extent, by serine and threonine) in position -1 of the peptidyl-tRNA. This phenomenon changes our understanding of the action mechanism of PTC inhibitors and requires further investigation [54].

Inhibitors blocking the polypeptide exit tunnel. The selectivity for the sequence of the nascent peptide is especially pronounced in the case of inhibitors that bind in the ribosome PET. Such drugs are common among the compounds targeting bacterial ribosomes (macrolide antibiotics being a classic example) [55, 56]. Interestingly, macrolides not only hinder progression of the nascent peptide, but also inhibit the PTC. When bound in the ribosomal tunnel, macrolides allosterically affect other regions of the ribosome, in particular, induce conformational rearrangements in the PTC [57]. Some anti-bacterial macrolides can bind to the large subunit of the archaeal ribosome (approximately to the same site as in the bacterial one [58-60]); however, none of them is currently known to interact in the same way with the eukaryotic ribosome [56]. Thus, 13-deoxytedanolide, a noncanonical macrolide targeting eukaryotic 60S subunit [61], binds at a completely different site (see below).

However, small-molecule drugs blocking or altering the peptide tunnel of the eukaryotic ribosome have recently been found among other classes of chemical compounds (figure, e.3). Two recently discovered inhibitors should be mentioned: PF-06446846 and PF06378503. These unusual drugs exhibit an unprecedentedly high selectivity toward the peptide sequence, so they only block the synthesis of a few proteins of the entire human proteome $[62,63]$. A structural study revealed that PF-06446846 binds within the PET [64] and induces ribosome stalling in the intermediate state of translocation due to the altered path of the nascent peptide. Even more recently, another type of eukaryotic translation inhibitors blocking the peptide tunnel was discovered aromatic polyketides. The binding of tetracenomycin $\mathrm{X}$ to the PET in the human ribosome was shown by structural methods and its activity was confirmed by experiments with reporter mRNAs both in vitro and in cultured cells
[65]. Interactions of tetracyclines Col-3 and doxycycline with the tunnel were studied biochemically [66]. The activity of some other tetracyclines, e.g., tigecycline $[67,68]$ and minocycline $[69,70]$, in eukaryotic systems has also been reported, although their binding sites remain unknown. Minocycline can be used for the treatment of autoimmune disorders, neuropathies, and viral infections and has a geroprotective potential. At the same time, the classic antibiotic tetracycline (Tet), which is widely used in medicine as an antibacterial drug, does not block translation in the eukaryotic system and binds to the bacterial ribosome at a completely different site than tetracenomycin X, doxycycline, and Col-3 [7].

Translocation inhibitors. Compounds blocking the ribosome at the translocation stage represent a significant portion of eukaryotic ribosome inhibitors (figure, e.6) and utilize various mechanisms of action. The classic eukaryote-specific inhibitor cycloheximide (also known as actidione or naramycin A) occupies the E-site of the $60 \mathrm{~S}$ subunit and prevents translocation of deacylated tRNA from the P-site [14, 17, 25, 71-75], although alternative mechanisms of its action have also been proposed $[34,76]$. Cycloheximide is widely used for the protein half-life assay, stabilization of elongation complexes for the polysome profile analysis, and high-throughput analysis of gene expression by ribosome profiling and translating ribosome affinity purification (TRAP) approaches [77]. It belongs to a group of chemicals called glutarimides, which also includes a number of less-studied translation inhibitors (e.g., streptimidone, actiphenol, acetoxycycloheximide, streptovitacin, isomigrastatin, and others [78-80]). Another glutarimide is lactimidomycin $[34,81]$, which binds to the same place in the E-site as cycloheximide, but has an additional lactone ring that hinders accommodation of its entire molecule [14]. Unlike cycloheximide, lactimidomycin cannot bind to the actively translating ribosomes, so its addition to the cells leads to the polysome disassembly [34]. This feature of lactimidomycin is exploited in the ribosome profiling assay to map initiation codons [82] (similarly to the previously described harringtonine). The inability of lactimidomycin to displace tRNA from the E-site is related to the slow accommodation of its large side radical [14]. The explanation can probably be applied to all the above cases when elongation inhibitors are inactive toward the ribosomes that have already been engaged in translation in a polysome but successfully interact with tRNA-free ribosomal complexes.

Lissoclimides (in particular, chlorolissoclimide and $\mathrm{C} 45$ ) isolated from sea molluscs bind to almost the same site on the $60 \mathrm{~S}$ subunit as glutarimide antibiotics. There is also a small degree of structural similarity, so these two classes of antibiotics might have a similar mechanism of action [83-85]. The same site is also targeted by another translation inhibitor with a completely different chemical structure, phyllanthoside [14]. The exact mechanism of 
its action remains unclear [35], but most likely, phyllanthoside inhibits translocation. The unique property of this drug is presumably formation of a covalent bond with the E-site resulting in its irreversible damage.

It is possible that some polyketides also bind at the same site, e.g., pederins (pederin, theopederins, psymberin, onnamide A, mycalamides, etc.) produced by symbionts of poisonous beetles and marine invertebrates [17, 86, 87], although reliable structural data have been obtained only for one of them, mycalamide A [60]. All these compounds inhibit translocation [17, 87, 88]. Two polyketides of another group, macrolides tedanolide and 13-deoxytedanolide, also block translocation by binding to the same location in the E-site as pederins [61, 89]. Surprisingly, structurally similar myriaporones [90] suppress elongation by phosphorylation of the elongation factor eEF2, rather than by direct binding to the ribosome $[91,92]$.

Eukaryote-specific inhibitors emetine and related cryptopleurine, as well as the universal antibiotics amicoumacin A and pactamycin, interact with the tRNAbinding region in the E-site, only on the small ribosomal subunit in this case [14, 93-97]. The elucidation of their action mechanism is complicated by the lack of structural data on their complexes with the eukaryotic ribosome in the presence of ligands. The ability of emetine and cryptopleurine to inhibit translocation has been known since the 1970s [17, 25, 98]. Chemically related cephaeline, tylophorine, tylocrebrine, tubulosin, DCB-3503, and YXM-110 also inhibit translocation and presumably bind to the same region of the 40S subunit [95-97, 99101]. Emetine has been used in medicine for more than a century as an anthelmintic and antiprotozoal (in particular, antiamoebic and antimalarial) medication; recently it was added to the list of potential drugs for combating coronavirus infection caused by SARS-CoV-2 [28].

Amicoumacin A, which affects the same stage of the ribosomal cycle, is considered as a promising anticancer drug [93]. In bacteria, it interacts simultaneously with mRNA and rRNA [102], preventing ribosome movement during the translocation. Since in eukaryotes the transcript is pulled through the ribosome not only during elongation, but also during scanning of the 5 '-untranslated region, one would expect amicoumacin A to inhibit the translation initiation. However, functional tests showed that this is not the case: amicoumacin A is a typical elongation inhibitor in eukaryotes as well [93]. Pactamycin interacts with the same region on the eukaryotic ribosome, but its mechanism of action is poorly understood [14, 18, 25]. For a long time, there had been unclear if this drug affects translation initiation or translation elongation (see discussion in [7, 103]). Finally, it was shown that pactamycin inhibits translocation of the bacterial ribosome [104], and our data suggest that it acts via a similar mechanism in eukaryotes [51]. Note that edeine, which is another antibiotic that binds to approxi- mately the same region of the small subunit [14], indeed inhibits initiation (see the corresponding section).

The atypical aminoglycoside hygromycin B blocks translocation by another mechanism. There are no structural data on its interaction with the eukaryotic ribosome. In bacteria, hygromycin B binds to the decoding center (DC) of the small ribosomal subunit, within the helix $\mathrm{h} 44$, and induces conformational changes that prevent the movement of mRNA and tRNA from the A-site to the P-site [103, 105]. In eukaryotes, its action mechanism is most likely the same [73, 106]. Other aminoglycosides have a different mechanism of action despite binding to the same site (see the text below); however, at high concentrations, some of them also block translocation. It has been well documented for bacterial ribosomes [107, 108] and can be associated with the anchoring of tRNA in the A-site upon antibiotic interaction with the classic aminoglycoside binding site in the helix h44 or its binding to alternative locations - the large subunit helix H69 or other sites $[109,110]$. In a eukaryotic system, this translocation block can be detected by the toeprinting assay only at very high concentrations of paromomycin and G418 [51].

In this section, we did not mention the drugs (for example, sordarin) that block translocation by suppressing the activity of the elongation factor eEF2. As these inhibitors do not affect the ribosome function directly, they will be discussed in a separate section.

Drugs inducing decoding errors. A separate class of inhibitors reduces translation fidelity by causing errors in the incorporation of amino acids by the ribosome (figure, e.4). A classic example of this type is the broad-spectrum aminoglycoside antibiotics [111]. Their main binding site on the eukaryotic ribosome is the helix h44 in the DC of the small subunit $[14,110]$. The binding stabilizes the DC conformation that is normally adopted only in the presence of the cognate aminoacyl-tRNA in the Asite [7]. This makes transpeptidation possible even when the A-site ligand does match the codon, resulting in the incorporation of a wrong amino acid. Aminoglycosides also induce stop codon readthrough, which makes them promising agents in the therapy of diseases caused by nonsense mutations (see below).

The highest activity against eukaryotic ribosomes is demonstrated by aminoglycosides with the 4,6- or 4,5disubstituted 2-deoxystreptamine (2-DOS) ring, such as geneticin (G418, widely used for genetic selection in eukaryotic cell cultures) and less active paromomycin, lividomycins, gentamicins, and amikacin [112-117]. Less toxic analogues of G418 and paromomycin (NB50, NB54, NB74, NB84, NB124, NB156, NB157 and others) are also highly active (for details, see [118, 119]), as well as the new promising compound TC007 [110, 120]. The similarities in the chemical structure of aminoglycosides sometimes lead to confusion (as it happened with gentamicin B1 [121]). However, most other known 
antibiotics of this type are presumably bacteriospecific due to the structural features of the helix h44 in the eukaryotic DC [14, 110, 122, 123]. However, this does not make them safe for eukaryotic cells, as they can suppress mitochondrial protein synthesis and cause severe side effects (primarily nephro- and ototoxicity), which limits their use as antibacterial drugs [124, 125]. As mentioned above, some aminoglycosides also inhibit translocation at elevated concentrations.

Other mechanisms of elongation failure. The universal inhibitor puromycin has a unique mechanism of action: it is a molecular mimetic of the aminoacylated CCA-end of tRNA. After entering the A-site, it causes a premature, factor-free termination of polypeptide synthesis [7, 11]. The activity of puromycin is well studied; its fluorescent and biotin derivatives are widely used for the visualization and quantitative analysis of newly synthesized proteins by many modern techniques such as PUNCH-P, SUnSET, Puro-PLA, RiboLace, and RPM, as well as for mRNA display [126]. Treating the cells with puromycin in a combination with cycloheximide leads to the accumulation of ribosomes exclusively on start codons, which facilitates their identification by ribosome profiling [127]. On the other hand, the combined effect of puromycin and other antibiotics depends on the ratio and concentrations of these compounds and cannot always be predicted, which may lead to artifacts $[128,129]$. The activity of puromycin is unique; for example, structurally similar antibiotic A201A (see above) does not act as a peptide bond acceptor and only inhibits the peptidyl transferase reaction $[13,40]$.

Among the bacterial translation inhibitors, there is a group of antibiotics that interact with the GAC of the large ribosomal subunit - the binding site for translational GTPases - and disrupt the functioning of these proteins. This group includes orthosomycins and thiopeptides (evernimicin, thiostrepton, micrococcin and others) that impede accommodation of translation factors on the ribosome [7]. In eukaryotes, the only currently known inhibitor of this type is the antimalarial drug mefloquine (figure, e.2). It binds to the ribosomal protein $\mathrm{uL} 13$ and the ES13 region of the 28S rRNA in the vicinity of the GAC [130]. Although its binding site is somewhat different from that of orthosomycins and thiopeptides, mefloquine most likely acts in a similar manner.

GAC is also targeted by plant, fungal and bacterial toxins called ribosome-inactivating proteins and ribotoxins, which cause depurination or cleavage of $28 \mathrm{~S}$ rRNA at a specific position in the sarcin-ricin loop [131, 132]. However, since these are high-molecular-weight inhibitors, their description is beyond the scope of this review. Besides, the binding of translational GTPases to the GAC is affected by the compounds directly interacting with these factors (described in one of the next sections).

Ribosome-targeting initiation inhibitors. The universal inhibitor edeine has an unusual mechanism of action (figure, i.6) [18]. It binds to the 40S subunit in the E-site [14]; however, unlike the above-described pactamycin, emetine, and other translocation inhibitors, it interferes with the recognition of the start codon during scanning (see discussion in [133, 134]). Most likely, edeine interferes with the binding or accommodation of the initiator Met-tRNA $A_{i}$ in the P-site, as has been shown for bacteria [7]. It is believed that at adequate concentrations, it does not interfere with the elongation and therefore can be used to analyze the mechanism of translation initiation, although this is sometimes questioned (see review in [135]). The use of edeine in the studies of translation initiation is complicated by the fact that mammalian cells are usually impermeable to this drug (at least to its most common form, edeine A1) [136].

2-(4-Methyl-1,6-dinitroanilino)-N-methylpropionamide (MDMP) affects the final stage of translation initiation, 60S subunit joining (figure, i.9), without interfering with other stages of the translation cycle [137-140]. It presumably targets the ribosome directly [141], but the details of its binding and the mechanism of action are still a mystery. It is also possible that mefloquine (elongation inhibitor discussed in the previous section) may also act at the stage of subunit joining, as it binds to the ribosome in the region shared by the elongation factors and eIF5B, the initiation factor promoting this stage (figure, i.7). The same stage of translation initiation in bacteria is inhibited by the mefloquine functional analogs, thiopeptides, which prevent the binding of IF2 (eIF5B ortholog) [7, 8].

More recently, targeted screening identified a group of compounds that interfere with the 60S subunit binding of initiation factor eIF6 (figure, i.8). These compounds are eIFsixty-1 (clofazimine), eIFsixty-4, and eIFsixty-6 (eIFsixty-4 exhibits the most pronounced effect on the translation and cell growth) [142]. eIF6 is involved mostly in the preparation of newly synthesized ribosomes for the first round of translation after their export from the nucleus, but it may also take part in the regular translation cycle [143]. Unfortunately, due to the lack of structural data, it is unknown whether these compounds target the $60 \mathrm{~S}$ subunit or the factor itself.

Ribosome inhibitors affecting termination. Smallmolecule drugs affecting translation termination can be potentially used in the treatment of diseases associated with the nonsense mutations in clinically relevant genes. However, very few specific termination inhibitors with a well-characterized mechanism of action are known (figure, t.2). Although reported to specifically block termination in bacteria [45], blasticidin S primarily affects the elongation stage in eukaryotes [46]. Another antibiotic, apidaecin (insect antimicrobial peptide), interacts with the bacterial ribosome and arrests translation at the stop codon [144]; however, there is no information on its activity in the eukaryotic systems. There is evidence that the anticancer agent girodazole (also known as giroline or RP 49532A) specifically inhibits termination by interact- 
ing with the E-site of the 60S subunit and blocking the release of the nascent peptide [89, 145, 146]. Unfortunately, its high toxicity prevents its clinical use [147], so the investigations of this compound have been dropped.

There are many more chemicals that are known to affect the stage preceding the release of the polypeptide, i.e., recognition of the stop codon, thus causing the stop codon readthrough (figure, t.1). Effective and non-toxic readthrough inducers could be widely used in medicine, as more than $10 \%$ of hereditary diseases are associated with the nonsense mutations in functionally important genes, while premature stop codons in tumor suppressors are often observed in cancer [148, 149]. Nonsense suppression therapy is aimed to increase the frequency of aberrant amino acid incorporation at the stop codon instead of hydrolysis of the peptidyl-tRNA [150, 151].

The best characterized inhibitors of this type are aminoglycosides (see above), in particular, G418, paromomycin, and gentamicin X2. A decrease in the decoding accuracy caused by these inhibitors leads to the impaired stop codon recognition [110, 111, 113, 115, 152]. Some aminoglycosides (such as G418), when taken at certain concentrations, can induce readthrough without a significant decrease in the overall fidelity of protein synthesis or dramatic effect on the gene expression [113, 115, 117]. Much efforts have been made to develop synthetic aminoglycoside derivatives that would increase the readthrough rate without exhibiting toxicity. An example of such compound is NB124 [114, 119].

However, it is likely impossible to completely eliminate the side effects of aminoglycoside therapy, as the long-term use of these compounds is associated with the risk of nephro- and ototoxicity [111, 153-155]. Therefore, great efforts are directed to finding nonaminoglycoside readthrough-inducing compounds. The best-known result of this search is ataluren (PTC124), a promising candidate in the treatment of cystic fibrosis and other hereditary diseases caused by nonsense mutations [156]. Unfortunately, its clinical trials have not yet been very successful $[157,158]$. Moreover, its activity as a readthrough inducer has been called into question, since ataluren was found to affect the stability of a reporter protein [159]. Beside ataluren, a number of other natural and synthetic non-aminoglycoside compounds were found to induce the stop codon readthrough by a still unknown mechanism: GJ071, GJ072, RTC13, RTC14, BZ16, amlexanox, and others identified in high-throughput biochemical screenings (for review, see [150, 160]). A similar effect is likely to be caused by TCP-1109 [161, 162], a derivative of the antibacterial dipeptide negamycin. The latter binds to the bacterial 30S subunit near the DC and causes decoding errors by interfering with the elongation and termination (see [163] and references therein). The nonsense suppression activity in the eukaryotic system was also shown for doxorubicin [152].
Surprisingly, several compounds have been found recently that dramatically enhance the effect of aminoglycosides on the translation termination. The phthalimide derivative CDX5-1, as well as the already mentioned mefloquine (and a number of other quinine derivatives), increase the efficiency of the G418-induced stop codon readthrough by two orders of magnitude [164, 165]. Such combination therapy might allow the use of low concentrations of aminoglycoside to ensure formation of sufficient amounts of full-length proteins encoded by genes with nonsense mutations without accompanying side effects.

Ribosome recycling inhibitors. The last stage of the translation cycle is ribosome recycling, which involves ribosomes release after peptidyl-tRNA hydrolysis at the stop codon [166]. Ribosome recycling factors and the underlying mechanisms differ between bacteria and eukaryotes [167]. No chemicals that selectively inhibit this stage have been found yet. However, ribosome recycling in bacteria is affected by aminoglycosides [168]. The structural basis of this activity [109] implies that these compounds might also affect eukaryotic ribosomes. Indeed, paromomycin, neomycin, and hygromycin have been shown to inhibit the dissociation of yeast ribosomes after termination (figure, r.1) [169, 170]. Translocation inhibitors, such as cycloheximide and lactimidomycin, have a similar effect $[169,170]$. In addition, compounds suppressing the working cycle of the eEF2 translocase (see the text below) can have some effect on the dissociation of ribosomal subunits in yeast $[169,171]$. This is somewhat surprising, however, as it is commonly believed that the involvement of translocase is a specific feature of the bacterial, rather than eukaryotic, type of ribosome recycling [167]. Thus, it cannot be ruled out that some of these observations are associated with the experimental system used by the authors to study ribosome recycling in yeast [169].

\section{INHIBITORS OF EUKARYOTIC TRANSLATION FACTORS}

In this section, we describe inhibitors that bind to translation factors and affect their activity (Table 2). The binding can occur both in solution and on the ribosome during the translation cycle. In the latter case, the drugs can contact both the translation factor and the ribosomal components, but we nevertheless decided to describe them in a separate section.

Inhibitors of elongation factors. A large group of chemically diverse substances, usually derived from marine organisms (both bacteria and eukaryotes), target the eEF1A elongation factor [172, 173]. They bind to a specific site on the protein surface and modulate protein conformational dynamics, which results in the inability of eEF1A to dissociate from the ribosome after GTP hydro- 
Table 2. Inhibitors of translation factors and ARSases

\begin{tabular}{|c|c|c|c|c|c|}
\hline Name & $\begin{array}{l}\text { Class, group } \\
\text { of chemical } \\
\text { substances }\end{array}$ & $\begin{array}{c}\text { Speci- } \\
\text { ficity } \\
(\mathrm{B}, \mathrm{A}, \mathrm{E})\end{array}$ & Target & $\begin{array}{l}\text { Stage of } \\
\text { the trans- } \\
\text { lation } \\
\text { cycle }\end{array}$ & Mechanism of action \\
\hline Aurintricarboxylic acid & $\begin{array}{l}\text { triphenyl- } \\
\text { methane }\end{array}$ & $\mathrm{B}, \mathrm{A}, \mathrm{E}$ & $\begin{array}{l}\text { 40S? tRNA? } \\
\text { mRNA? }\end{array}$ & $\mathrm{I}(\mathrm{E})$ & $\begin{array}{l}\text { inhibits eIF2-GTP-Met-tRNA } \\
\text { complex formation (HC inhibits } \\
\text { mRNA and tRNA binding to the } \\
\text { ribosome) }\end{array}$ \\
\hline Pyrocatechol violet & $-/ /-$ & B? A? E & $-/ /-$ & I (E) & $-/ /-$ \\
\hline Gallin & $\begin{array}{l}\text { xanthene-like, } \\
\text { gallin/fluorescein } \\
\text { analog }\end{array}$ & B? A? E & $-/ /-$ & $\mathrm{I}(\mathrm{E})$ & $-/ /-$ \\
\hline Gallein & $-/ /-$ & $\mathrm{E} ?$ & $-/ /-$ & $\mathrm{I} ?$ & $-/ /-$ \\
\hline NSC 119893 & $-/ /-$ & $\mathrm{E}$ ? & $\begin{array}{l}\text { eIF2-GTP-Met- } \\
\text { tRNA }_{\mathrm{i}} \text { ? }\end{array}$ & $\mathrm{I}$ & $\begin{array}{l}\text { inhibits eIF2-GTP-Met-tRNA } \\
\text { complex formation }\end{array}$ \\
\hline NSC 119889 & $-/ /-$ & $\mathrm{E} ?$ & $-/ /-$ & I & $-/ /-$ \\
\hline Showdomycin & uridine analog & $\mathrm{B}, \mathrm{A}, \mathrm{E}$ & eIF2, eEF2? & $\mathrm{I}, \mathrm{E}$ & $-/ /-$, eEF2 inhibitor? \\
\hline Didemnin B & cyclic peptide & $\mathrm{E}$ & eEF1A & $\mathrm{E}$ & $\begin{array}{l}\text { prevents eEF1A-GDP dissociation } \\
\text { from the ribosome }\end{array}$ \\
\hline $\begin{array}{l}\text { Aplidine/plitidipsin/ } \\
\text { dehydrodidemnin B }\end{array}$ & $-/ /-$ & $\mathrm{E}$ & eEF1A & $\mathrm{E}$ & $-/ /-$ \\
\hline Nannocystin A & $-/ /-$ & $\mathrm{E}$ & eEF1A & $\mathrm{E}$ & $-/ /-$ \\
\hline Cytotrienin A & $-/ /-$ & $\mathrm{E}$ & eEF1A & $\mathrm{E}$ & $-/ /-$ \\
\hline Tamandarin A & $-/ /-$ & $\mathrm{E}$ & eEF1A & $\mathrm{E}$ & $-/ /-$ \\
\hline Ansatrienin A/mycotrienin I & $\begin{array}{l}\text { cyclic peptide, } \\
\text { ansamycin }\end{array}$ & $\mathrm{E}$ & eEF1A & $\mathrm{E}$ & $-/ /-$ \\
\hline Trienomycin A & $-/ /-$ & $\mathrm{E}$ & eEF1A? & $\mathrm{E}$ & $-/ /-$ \\
\hline Monoenomycin & $-/ /-$ & $?$ & eEF1A? & $\mathrm{E} ?$ & $-/ /-$ \\
\hline Trienomycin $\mathrm{J}$ & $-/ /-$ & $?$ & eEF1A? & $\mathrm{E} ?$ & $-/ /-$ \\
\hline Trierixin & $-/ /-$ & $\mathrm{E}$ & eEF1A? & $\mathrm{E}$ & $-/ /-$ \\
\hline Quinotrierixin & $-/ /-$ & $\mathrm{E}$ & eEF1A? & $\mathrm{E}$ & $-/ /-$ \\
\hline Ternatin & $\begin{array}{l}\text { diterpene alka- } \\
\text { loid }\end{array}$ & $\mathrm{E}$ & eEF1A & $\mathrm{E}$ & $-/ /-$ \\
\hline $\begin{array}{l}\text { Tosylphenylalanylchloro- } \\
\text { methane }\end{array}$ & $\begin{array}{l}\text { chloromethyl } \\
\text { ketone }\end{array}$ & $\mathrm{B}, \mathrm{A}, \mathrm{E} ?$ & eEF1A? & $\mathrm{E}$ & $-/ /-$ \\
\hline Bouvardin & $\begin{array}{l}\text { cyclic peptide, } \\
\text { bouvardin group }\end{array}$ & $\mathrm{E}$ & eEF2 & $\mathrm{E}$ & $\begin{array}{l}\text { prevents eEF2 GDP dissociation } \\
\text { from the ribosome }\end{array}$ \\
\hline SVC112 & $-/ /-$ & $\mathrm{E}$ & eEF2? & & $-/ /-$ \\
\hline RA-VII & $-/ /-$ & $\mathrm{E}$ & eEF2? & $\mathrm{E}$ & $-/ /-$ \\
\hline DDD107498 & $\begin{array}{l}\text { quinoline deriva- } \\
\text { tive }\end{array}$ & $\mathrm{E}^{*}$ & eEF2 & $\mathrm{E}$ & $-/ /-$ \\
\hline Sordarin & $\begin{array}{l}\text { cyclic diterpene } \\
\text { glycoside, sor- } \\
\text { darin analog }\end{array}$ & $\mathrm{E}^{*}$ & eEF2 & $\mathrm{E}$ & $-/ /-$ \\
\hline GM193663 & $-/ /-$ & $\mathrm{E}^{*}$ & eEF2 & $\mathrm{E}$ & $-/ /-$ \\
\hline GR135402 & $-/ /-$ & $\mathrm{E}^{*}$ & eEF2 & $\mathrm{E}$ & $-/ /-$ \\
\hline Moriniafungin & $-/ /-$ & $\mathrm{E}^{*}$ & eEF2 & $\mathrm{E}$ & $-/ /-$ \\
\hline $\begin{array}{l}\text { DAO/dihydroarmillyl- } \\
\text { orsellinate }\end{array}$ & $\begin{array}{l}\text { polyketide, } \\
\text { sesquiterpene }\end{array}$ & $\mathrm{E}$ & eEF2 & & $-/ /-$ \\
\hline Arnamial & $-/ /-$ & $\mathrm{E}$ & eEF2 & & $-/ /-$ \\
\hline Fusidic acid & steroid & $\mathrm{BA}(\mathrm{E})$ & $(\mathrm{eEF} 2)$ & $\mathrm{E}$ & $-/ /-?(\mathrm{HC})$ \\
\hline
\end{tabular}


Table 2. (Contd.)

\begin{tabular}{|c|c|c|c|c|c|}
\hline Name & $\begin{array}{l}\text { Class, group } \\
\text { of chemical } \\
\text { substances }\end{array}$ & $\begin{array}{c}\text { Speci- } \\
\text { ficity } \\
(\mathrm{B}, \mathrm{A}, \mathrm{E})\end{array}$ & Target & $\begin{array}{c}\text { Stage of } \\
\text { the trans- } \\
\text { lation } \\
\text { cycle }\end{array}$ & Mechanism of action \\
\hline Allolaurinterol & sesquiterpene & $\mathrm{E}$ & eIF4A & I & inhibits eIF4A ATPase activity \\
\hline Elisabatin A & $-/ /-$ & E & eIF4A & I & $-/ /-$ \\
\hline Rocaglamide A/Roc A & rocaglate & $\mathrm{E}$ & eIF4A & I & $\begin{array}{l}\text { inhibits eIF4A helicase activity and } \\
\text { eIF4F binding to mRNA }\end{array}$ \\
\hline Silvestrol & $-/ /-$ & $\mathrm{E}$ & eIF4A & I & inhibits eIF4A helicase activity \\
\hline Pateamine A & macrodiolide & E & eIF4A & I & impedes eIF4A binding to eIF4G \\
\hline Hippuristanol & steroid & $\mathrm{E}$ & eIF4A & I & allosteric inhibitor of eIF4A \\
\hline Ribavirin & $\mathrm{m}^{7} \mathrm{G}$ analog & $\mathrm{E}$ & eIF4E? & I & $\begin{array}{l}\text { competes with } \mathrm{m}^{7} \mathrm{G} \text {-cap for eIF4E } \\
\text { binding? }\end{array}$ \\
\hline 4EGI-1 & & $\mathrm{E}$ & eIF4E-eIF4G & I & impedes eIF4E binding to eIF4G \\
\hline 4E1RCat & & $\mathrm{E}$ & eIF4E-eIF4G & I & $-/ /-$ \\
\hline 4E2RCat & & $\mathrm{E}$ & eIF4E-eIF4G & I & $-/ /-$ \\
\hline Gephyronic acid & polyketide & $\mathrm{E}$ & $(\mathrm{eIF} 2)$ & I & binds to eIF2 and affects its activity? \\
\hline CM16 & beta-carboline & $\mathrm{E}$ & eIF1AX, eIF3 & I & inhibits eIF1AX and eIF3? \\
\hline Ochratoxin A & isocoumarin & $\mathrm{B}, \mathrm{A}, \mathrm{E}$ & Phe-tRNA synthetase & $\mathrm{E}$ & inhibits Phe-tRNA synthetase \\
\hline Borrelidin & polyketide & $\mathrm{B}, \mathrm{A}, \mathrm{E}$ & Thr-tRNA synthetase & E & inhibits Thr-tRNA synthetase \\
\hline Reveromycin A & $-/ /-$ & $\mathrm{E}$ & Ile-tRNA synthetase & $\mathrm{E}$ & inhibits Ile-tRNA synthetase \\
\hline Spirofungin A & $-/ /-$ & $\mathrm{E}$ & $-/ /-$ & $\mathrm{E}$ & $-/ /-$ \\
\hline Furanomycin & Ile analog & B? A? E & $-/ /-$ & & $-/ /-$ \\
\hline Methionine sulfamide & Met analog & $\mathrm{B}, \mathrm{A}, \mathrm{E}$ & Met-tRNA synthetase & $\mathrm{E}$ & inhibits Met-tRNA synthetase \\
\hline Methionyl adenylate & $-/ /-$ & $\mathrm{B}, \mathrm{A}, \mathrm{E}$ & $-/ /-$ & $\mathrm{E}$ & $-/ /-$ \\
\hline Methionine hydroxamate 20 & $-/ /-$ & $\mathrm{B}, \mathrm{A}, \mathrm{E}$ & $-/ /-$ & $\mathrm{E}$ & $-/ /-$ \\
\hline Ethionine & $-/ /-$ & $\mathrm{B}, \mathrm{A}, \mathrm{E}$ & $-/ /-$ & $\mathrm{I}, \mathrm{E}$ & $-/ /-$ \\
\hline Tavaborole/AN2690 & oxaborol & $\mathrm{E}$ & Leu-tRNA synthetase & $\mathrm{E}$ & inhibits Leu-tRNA synthetase \\
\hline Histidinol & His analog & $\mathrm{B}, \mathrm{A}, \mathrm{E}$ & His-tRNA synthetase & $\mathrm{E}$ & $\begin{array}{l}\text { inhibits His-tRNA synthetase and } \\
\text { His biosynthesis }\end{array}$ \\
\hline Phosmidosine & $\begin{array}{l}\text { nucleoside ami- } \\
\text { dophosphite }\end{array}$ & $\mathrm{E}$ & Pro-tRNA synthetase? & $\mathrm{E}$ & inhibits Pro-tRNA synthetase \\
\hline Febrifugine & \begin{tabular}{|l} 
quinazolinone \\
alkaloid, \\
febrifugine group
\end{tabular} & $?$ & $-/ /-$ & $\mathrm{E}$ & $-/ /-$ \\
\hline Halofuginone & $-/ /-$ & $?$ & $-/ /-$ & $\mathrm{E}$ & $-/ /-$ \\
\hline Purpuromycin & polyketide & $\mathrm{B}, \mathrm{A}, \mathrm{E}$ & tRNA & $\mathrm{E}$ & $\begin{array}{l}\text { binds any tRNA, prevents its } \\
\text { aminoacylation }\end{array}$ \\
\hline GC7 & $\begin{array}{l}\text { spermidine } \\
\text { analog }\end{array}$ & $\mathrm{B}, \mathrm{A}, \mathrm{E}$ & DHPS/eIF5A & $\mathrm{E}$ & $\begin{array}{l}\text { inhibits hypusine synthesis necessary } \\
\text { for eIF5A activity }\end{array}$ \\
\hline Semapimod/CNI1493 & anilide & $\mathrm{E}$ & $-/ /-$ & $\mathrm{E}$ & $-/ /-$ \\
\hline $\begin{array}{l}\text { Deoxyspergualin/ } \\
\text { gusperimus }\end{array}$ & & $\mathrm{E}$ & $-/ /-$ & $\mathrm{E}$ & $-/ /-$ \\
\hline DHSI-15 & & E & $-/ /-$ & $\mathrm{E}$ & $-/ /-$ \\
\hline Ciclopirox/loprox & $\begin{array}{l}\text { pyridone deriva- } \\
\text { tive }\end{array}$ & $\mathrm{E}$ & DOHH/eIF5A & $\mathrm{E}$ & $\begin{array}{l}\text { inhibits hypusine synthesis necessary } \\
\text { for eIF5A activity (iron chelator) }\end{array}$ \\
\hline Deferiprone & $-/ /-$ & $\mathrm{E}$ & $-/ /-$ & $\mathrm{E}$ & $-/ /-$ \\
\hline Mimosine & $-/ /-$ & E & $-/ /-$ & E & $-/ /-$ \\
\hline
\end{tabular}

Note. Letter codes and designations - as in Table 1. 
lysis (figure, e.2), thus blocking elongation. It is unclear why this particular stage is especially attractive for inhibition, but the same mechanism of action is shared by unrelated compounds, such as cyclic depsipeptides from the didemnin group [174] (didemnins A, B, C, and $\mathrm{M}$ [175, 176], aplidine/plitidipsin [177], tamandarins A and B [178]), ansamycins (cytotrienin A [179] and similar trienomycins, trierixin, quinotrierixin and ansatrienins $\mathrm{A}$ and B, also called mycotrienins I and II [173, 180]), and the cyclic peptide ternatin [173]. Nannocystin A is another macrocyclic compound with a more complex structure, but the same mechanism of action [181]. All these drugs are, in fact, eukaryote-specific functional analogs of the well-known antibacterial inhibitor kirromycin, which stabilizes the EF1 $\alpha$ complex with aminoacyltRNA on the ribosome [7].

A distinct group of compounds uses a similar mechanism to inhibit another elongation factor, the eEF2 translocase (figure, e.7). The classic examples are the fungicide sordarin and its numerous derivatives (moriniafungin, GM193663, GR135402, azasordarins, etc.), which target eEF2 in some fungi, but are harmless for human cells [182-185]. Their binding to eEF2 [186, 187] prevents its dissociation from the ribosome and thus freezes the elongation complex in a post-translocational state [188]. The action of sordarin resembles that of the well-known antibacterial antibiotic fusidic acid, although there is a difference in the details of its interaction with the factor (discussed in [188]). Fusidic acid itself is likely unable to specifically inhibit translocation in eukaryotic cells, although at high concentration it may have some effects [189].

The inhibitory activity of sordarin requires diphthamide, an AE-specific, uniquely modified amino acid only found in eEF2 [190]. Interestingly, diphthamide is a target for a large group of bacterial protein toxins (diphtheria toxin and others) that inactivate eEF2 by ADPribosylation of this residue. Yet, inhibitors of protein nature are beyond the scope of our review, so we refer interested readers to the publication [191].

The question of whether there is a sordarin analogue that is active in mammalian cells is still open. Most likely, similar mechanism of action can be attributed to the cyclic peptide bouvardin (anticancer drug) and its derivatives (RA-VII, SVC112, etc.) [192, 193]. It had been reported that purpuromycin may act in a similar way [194], but later its activity was linked to the inhibition of aminoacylation (see below).

Recently, the antimalarial drug DDD107498, which is non-toxic to human cells, has been discovered and shown to target eEF2 of the malaria parasite [195]. Interestingly, it contains the same quinoline heterocycle as the above mefloquine. It cannot be ruled out that all quinine-like compounds used for malaria treatment disrupt the interaction of elongation factors with the ribosome [130].
eIF5A is another elongation factor (formerly erroneously believed to be an initiation factor) that can also serve as a target for the inhibitors, more precisely, those that target the synthesis of hypusine, a uniquely modified amino acid residue required for the eIF5A activity [196]. Conversion of the conserved lysine residue to hypusine can be blocked at different stages by a number of compounds, leading to the accumulation of inactive factor. Such inhibitors include GC7, semapimod (CNI1493), deoxyspergualin (gusperimus), DHSI15, ciclopirox, deferiprone, and mimosine (see review in [196]). These compounds, however, are not highly specific. Some of them inactivate other enzymes involved in the metabolism and transport of polyamines and other molecules, while ciclopirox, deferiprone, and mimosine are iron chelators. Mimosine was previously shown to indirectly target another translation factor, eIF3, by specifically downregulating the production of the eIF3a subunit [197].

Inhibitors of initiation factors. In contrast to relatively conserved elongation factors, many eukaryotic components of the translation initiation machinery have appeared in the evolution with the emergence of ribosomal scanning and, therefore, are eukaryote-specific. This primarily refers to the eIF4 group of initiation factors, which facilitate mRNA binding to the ribosome and direct scanning [1]. The small cap-binding protein eIF4E, a component of the heterotrimeric eIF4F complex, anchors to the $\mathrm{m}^{7} \mathrm{G}$-capped $5^{\prime}$-end of mRNA, while its partner, the mRNA-binding factor eIF4G, serves as a platform for the ATP-dependent RNA helicase eIF4A and bridges mRNA with the factors bound to the ribosomal 43S preinitiation complex [1].

Targeted high-throughput screening [198] identified compound 4EGI-1 that binds to eIF4E and allosterically disrupts its association with eIF4G (figure, i.3), while simultaneously enhancing its interaction with the inhibitory protein 4E-BP1 [199, 200]. Thus, 4EGI-1 suppresses cap-dependent mRNA translation with no effect on the transcripts employing non-canonical initiation mechanisms [e.g., viral mRNAs with internal ribosome entry sites (IRESs) or cellular mRNAs with cap-independent translation enhancers (CITEs)] [201]. Another screening identified two more compounds with a similar mechanism of action, 4E1RCat [202] and 4E2RCat [203]. The latter exhibited strong antiviral activity and was able to suppress the propagation of coronaviruses.

There is a hypothesis that some cardiac glycosides (e.g., ouabain) affect translation in a similar way [204]. Transcriptional changes induced by cardiac glycosides strongly resemble those caused by the classic elongation inhibitors (cycloheximide, anisomycin, emetine, etc.) [205]. Moreover, Perne et al. showed suppression of protein synthesis in the cells treated with these substances [206]. However, these effects are most likely secondary or temporary, since the similarity of transcription patterns, strongly pronounced at the 6th hour of exposure, disap- 
peared by $24 \mathrm{~h} \mathrm{[205].} \mathrm{It} \mathrm{is} \mathrm{also} \mathrm{possible} \mathrm{that} \mathrm{these} \mathrm{drugs}$ inhibit the PI3K/Akt/mTOR signaling pathway [207] (see the text below) or the initiation factor eIF4A [208]. However, in direct experiments in a mammalian cell-free system, cardiac glycosides failed to noticeably inhibit translation of reporter mRNAs (Lashkevich and Dmitriev, personal communication).

eIF4E interaction with the $\mathrm{m}^{7} \mathrm{G}$ cap at the mRNA $5^{\prime}$-end is also very important. Kentsis et al. stated [209] that this interaction can be disrupted by a competitive inhibitor (figure, i.4) - the antiviral drug ribavirin (and its triphosphorylated form), which structurally resembles the $\mathrm{m}^{7} \mathrm{G}$-cap. This statement was challenged by two separate groups [210, 211], yet the authors of the original study remained unconvinced [212]. Later, ribavirin was shown to suppress the Akt signaling pathway [213], which can explain its effects.

The J. Pelletier group has discovered a number of new inhibitors that target another component of the eIF4F complex - the RNA helicase eIF4A [214, 215]. Hippuristanol, a polyoxygenated steroid, binds and allosterically inhibits eIF4A (figure, i.5) [216], while pateamine A prevents eIF4A interaction with eIF4G (figure, i.2) and increases its RNA binding activity [217, 218]. Rocaglates (including rocaglamide A, silvestrol, and other flavaglines) also suppress the activity of eIF4A, but their mechanism of action is less characterized (figure, i.5) [219-221]. Ribosome profiling revealed that eIF4A inhibition by some of these drugs causes a sequence-specific arrest of the scanning ribosome at the $5^{\prime}$-untranslated region (see discussion in [221]). In the latest study, rocaglates were found to act in a dual fashion: first, they disturb the landing of eIF4F and the initiator complex on the $5^{\prime}$-cap and then inhibit the ribosomal scanning [221]. Numerous derivatives of the eIF4A inhibitors have been obtained and characterized for the use in the anticancer therapy [221, 222]. Recent screening revealed two new, highly specific ATP-competitive inhibitors of eIF4A - elisabatin A and allolaurinterol [223]. There are also a number of drugs (e.g., nucleoside analogs such as hypericin) that target translational RNA helicases (not only eIF4A, but also DDX3) in a less specific manner [214].

Translation initiation is the primary target of aurintricarboxylic acid (ATA) and similar triphenylmethane and xanthene dyes (pyrocatechol violet, gallin, and some others) that are universal inhibitors widely used in early in vitro studies of protein synthesis [18, 224, 225]. However, the specificity of their action is questioned, since at higher concentrations, they can also inhibit other translation steps (reviewed in [10]). ATA and similar chemicals are likely to reduce both specific and nonspecific RNA-protein interactions [226, 227], thus inhibiting factordependent and non-enzymatic tRNA binding to the ribosome during initiation (figure, i.1) [228]. This relaxed specificity, as well as inability to enter intact mammalian cells [229], have led to the loss of interest in their use for studying eukaryotic translation.

However, in 2004, while searching for new translation inhibitors, several similar xanthene-based compounds, such as gallein and fluorescein derivatives, were discovered that produced an interesting mRNA-specific effect on the translation of reporter transcripts [230]. Their addition to a cell-free system suppressed capdependent translation, but had no effect on the protein synthesis directed by the IRES of the hepatitis $C$ virus (HCV). Among other features, this IRES is known to provide the eIF2-independent translation initiation under certain conditions [231, 232]. A more detailed study of compounds NSC 119889 and NSC 119893 (the latter is cell-permeable) showed that they prevent the binding of the initiator Met-tRNA $\mathrm{i}_{\mathrm{i}}$ to eIF2 (figure, i.1) and thereby block the formation of the $43 \mathrm{~S}$ preinitiation complex [232], an essential intermediate of the canonical translation initiation.

Several other translation factors (e.g., eIF1AX and eIF3 [197, 233]) were also identified as targets for smallmolecule inhibitors, but these interactions have not yet been sufficiently studied. Furthermore, factor-mediated functions can also be blocked by the non-hydrolyzable analogs of ribonucleoside triphosphates. Thus, GTP analogs (GMPPNP and GMPPCP) inhibit initiation, elongation, and termination stages, while ATP analogs usually interfere with initiation, ribosome recycling and functioning of (ARSases). However, these inhibitors are obviously nonspecific and, in most cases, cell-impermeable [229].

\section{INHIBITORS OF AMINOACYL-tRNA SYNTHETASES}

Beside translation factors, small chemical compounds can target other auxiliary components of the protein synthesis machinery. Unsurprisingly, inhibitors of ARSases specifically block protein synthesis (Table 2 and figure, e.1). Sulfonamides, hydroxamates, and other derivatives of amino acids and peptides, as well as esters and hydroxamates of aminoacyl adenylates, inhibit the synthesis of the corresponding aminoacyl-tRNAs. For example, L-methioninol, methionyl sulfamide, Lmethionyl hydroxamate, and methionyl adenylate derivatives specifically inhibit the synthesis of Met-tRNA [234, 235], while the Trp antagonist 6-fluorotryptophan inhibits amino acid activation in the tryptophanyl adenylate synthesis [236]. There are numerous studies exploring such amino acid derivatives [10], and this field is growing rapidly due to the development of computeraided drug design [237-239]. In rare cases, amino acid analogs (e.g., ethionine, an S-ethyl analogue of Met) not only inhibit ARSases, but can be also incorporated into proteins, leading to cell death [240]. 
Most of the above compounds are universal protein synthesis inhibitors and can freely pass into a living cell. However, due to the high similarity to amino acids, they can affect other cellular processes. In addition, their effective concentrations are usually in a relatively high (millimolar) range. However, there are several specific ARSase inhibitors produced by some pathogenic organisms with a much higher affinity for their targets. For example, borrelidin, a product of marine bacteria, is a highly specific inhibitor of Thr-tRNA synthetase [241]; ochratoxin A from mold fungi targets Phe-tRNA synthetase [242]; febrifugine and halofuginone inhibit ProtRNA synthetase [243, 244], while tavaborole inhibits Leu-tRNA synthetase [245]. Ile-tRNA synthetase is targeted by spirofungin A [246] and reveromycin A [247, 248], although the effects of the latter might be cell typespecific [249]. Finally, the unusual inhibitor purpuromycin can bind any tRNA and prevent its aminoacylation without affecting the binding of already aminoacylated tRNAs to the elongation factors, ribosome, and other translational components [250], which makes it somewhat special.

Many ARSase inhibitors are of great medical importance, as they have the immunosuppressive activity and are extensively used as antimicrobial, antitumor, and antiparasitic agents [239, 251]. Their effects on the living cell are usually mediated not only by the suppression of protein synthesis, but also by triggering a special type of stress response [252] caused by the accumulation of deacylated tRNAs in the cytoplasm and collisions of translating ribosomes (see below).

\section{INHIBITORS OF SIGNALING PATHWAYS INVOLVED IN TRANSLATIONAL CONTROL}

Like any other complex process in the cell, almost every step of protein biosynthesis is precisely regulated at multiple levels. Eukaryotes have a number of signaling cascades ending in specialized enzymes that modify translational components [253, 254]. These regulatory pathways deserve a separate review, so we will not discuss all of them, but will focus on some components of these cascades serving as targets for protein synthesis inhibitors (Table 3 and figure, s.1-s.9).

Inhibitors of mTOR kinase and the PI3K/Akt/mTOR signaling cascade. A very important signaling pathway is the PI3K/Akt/mTOR regulatory cascade, which integrates signals from insulin and a number of growth factors, as well as from the sensors of nutrient availability $[255,256]$. One of the direct substrates of the mTOR kinase is the above-mentioned inhibitor protein 4E-BP1. When phosphorylated, it remains inactive and does not interfere with the functioning of the cap-binding factor eIF4E [256]. But if mTOR is inhibited, 4E-BP1 displaces eIF4G from its complex with eIF4E. This results in a moderate decline in total protein synthesis and a much more severe suppression of translation of a special class of mRNA transcripts with the 5 '-terminal oligopyrimidine tract (5'-TOP) [201, 255]. 5'-TOP mRNAs mainly encode components of the translational apparatus (ribosomal proteins, translation factors, etc.) [257, 258], the synthesis of which is especially important for actively proliferating and metabolizing cells, including tumor and stem cells [259]. The activity of this pathway strongly decreases with age [260] and can affect the lifespan [261]. mTOR substrates also include S6 kinases 1/2, which phosphorylate the ribosomal protein eS6 (RPS6), translation initiation factor eIF4B, eIF4A inhibitory protein PDCD4, and, indirectly, eEF2 [253, 254]. All this makes mTOR an attractive target for clinically relevant drugs [259]. By now, many mTOR inhibitors have already been found (see Table 3 for the most commonly used ones). They can be divided into two types: direct ATP-competitive inhibitors that target the active site of the kinase (figure, s.6) and allosteric inhibitors that act indirectly through the FKBP12 protein, a component of the mTORC1 kinase complex (figure, s.7). mTORC1 is mainly responsible for the translation-related branch of the mTOR pathway. Many commonly used drugs, such as torin 1, torin 2, INK128, AZD-8055, OSI-027, WYE132, Ku0063794, and PP242 [255, 262], are direct mTOR inhibitors, while allosteric inhibitors include the widelyknown natural macrolide rapamycin (sirolimus) and its synthetic analogs called rapalogs (everolimus, temsirolimus, and ridaforolimus) [255, 259]. Rapalogs have long been successfully used in anticancer therapy and as immunosuppressants in organ transplantation. There is also a growing interest in mTOR inhibitors as geroprotectors, since they have been shown to increase longevity in a number of animal models [261].

Some compounds known to interfere with the capdependent translation target the upstream components of the PI3K/Akt/mTOR cascade rather than mTOR itself (figure, s.5). As we move up the cascade, the effects of the inhibitors expand and increase, while the specificity decreases. Nevertheless, PI3K inhibitors (e.g., wortmannin and LY294002) are often used to suppress the capdependent translation. It should be noted, however, that the kinase domains of PI3K and mTOR belong to the same family and thus share common inhibitors [263]. The top hits in a recent screening for the compounds suppressing translation of 5'-TOP mRNAs [264] included inhibitors of each of the PI3K/Akt/mTOR cascade components (and quite unexpectedly, the GCN2 kinase; see below). It is also possible that cardiac glycosides target the mTOR pathway with a certain degree of specificity [207].

However, it should be kept in mind that mTOR has several dozen substrates, including those unrelated to translation. Therefore, the effect of its inhibitors on the protein synthesis is not highly specific. The same can be said about compounds targeting the MAPK cascades 
Table 3. Inhibitors of the general signaling pathways that regulate protein biosynthesis in eukaryotic cells

\begin{tabular}{|c|c|c|c|c|}
\hline Name & $\begin{array}{l}\text { Class, group } \\
\text { of chemical substances }\end{array}$ & Target & $\begin{array}{l}\text { Stage of } \\
\text { the trans- } \\
\text { lation } \\
\text { cycle }\end{array}$ & Mechanism of action \\
\hline Rapamycin/sirolimus & $\begin{array}{l}\text { macrolide, rapamycin } \\
\text { group }\end{array}$ & $\begin{array}{l}\text { FKBP12/ } \\
\text { mTORC1 }\end{array}$ & $\mathrm{I}(\mathrm{E})$ & $\begin{array}{l}\text { allosteric mTOR inhibitor (mTORC1 only); } \\
\text { activates 4E-BP1 and suppresses cap-depend- } \\
\text { ent translation, primarily 5'-TOP mRNAs }\end{array}$ \\
\hline Everolimus & $\begin{array}{l}\text { macrolide, rapamycin } \\
\text { group (rapalog) }\end{array}$ & $-/ /-$ & $\mathrm{I}(\mathrm{E})$ & $-/ /-$ \\
\hline Temsirolimus & $-/ /-$ & $-/ /-$ & I $(E)$ & $-/ /-$ \\
\hline Ridaforolimus & $-/ /-$ & $-/ /-$ & $\mathrm{I}(\mathrm{E})$ & $-/ /-$ \\
\hline Torin 1 & pyridinonequinoline & mTOR & $\mathrm{I}(\mathrm{E})$ & $\begin{array}{l}\text { ATP-competitive mTOR inhibitor (both } \\
\text { mTORC1 and mTORC2), activates 4E-BP1 etc. }\end{array}$ \\
\hline Torin 2 & $-/ /-$ & $-/ /-$ & $\mathrm{I}(\mathrm{E})$ & $-/ /-$ \\
\hline Torkinib/PP242 & pyrazolopyrimidine & $-/ /-$ & $\mathrm{I}(\mathrm{E})$ & $-/ /-$ \\
\hline $\begin{array}{l}\text { Sapanisertib/MLN0128/ } \\
\text { INK128/TAK-228 }\end{array}$ & benzoxazole & $-/ /-$ & $\mathrm{I}(\mathrm{E})$ & $-/ /-$ \\
\hline Vistusertib/AZD2014 & $\begin{array}{l}\text { phenylpyridine, } \\
\text { vistusertib group }\end{array}$ & $-/ /-$ & $\mathrm{I}(\mathrm{E})$ & $-/ /-$ \\
\hline AZD8055 & $-/ /-$ & $-/ /-$ & $\mathrm{I}(\mathrm{E})$ & $-/ /-$ \\
\hline Dactolisib/NVP-BEZ235 & phenylquinoline & $\begin{array}{c}\text { PI3K } \\
\text { (mTOR) }\end{array}$ & $\mathrm{I}(\mathrm{E})$ & $-/ /-$ \\
\hline Voxtalisib/SAR245409/XL765 & pyrazolylpyridine & $-/ /-$ & $\mathrm{I}(\mathrm{E})$ & $-/ /-$ \\
\hline Samotosilib/LY3023414 & imidazoquinoline & $-/ /-$ & $\mathrm{I}(\mathrm{E})$ & $-/ /-$ \\
\hline Omipalisib/GSK2126458 & quinoline & $-/ /-$ & $\mathrm{I}(\mathrm{E})$ & $-/ /-$ \\
\hline Wortmannin & steroid & $-/ /-$ & $\mathrm{I}(\mathrm{E})$ & $-/ /-$ \\
\hline LY294002 & morpholine derivative & $-/ /-$ & $\mathrm{I}(\mathrm{E})$ & $-/ /-$ \\
\hline Bimiralisib/PQR309 & pyridinamine & $-/ /-$ & $\mathrm{I}(\mathrm{E})$ & $-/ /-$ \\
\hline $\begin{array}{l}\text { Gedatolisib/PKI-587/ } \\
\text { PF-05212384 }\end{array}$ & benzoylpiperidine & $-/ /-$ & $\mathrm{I}(\mathrm{E})$ & $-/ /-$ \\
\hline Adavosertib/MK1775 & piperazine & GCN2? & I & $\begin{array}{l}\text { activates GCN2?, leads to suppression of } 5^{\prime} \text { - } \\
\text { TOP mRNA translation }\end{array}$ \\
\hline Dabrafenib & sulfanilide & $-/ /-$ & I & $-/ /-$ \\
\hline BTdCPU & $\mathrm{N}, \mathrm{N}$-diaryl urea & HRI & I & activates HRI, induces eIF2 phosphorylation \\
\hline ССТ020312 & quinoline & PERK & I & activates PERK, induces eIF2 phosphorylation \\
\hline MK-28 & methylaminopentanamide & $-/ /-$ & I & $-/ /-$ \\
\hline Salubrinal & $\begin{array}{l}\text { quinoline, salubrinal } \\
\text { group }\end{array}$ & $\begin{array}{c}\text { GADD34/ } \\
\text { PP1?, } \\
\text { CReP/PP1? }\end{array}$ & I & $\begin{array}{l}\text { inhibits eIF2-specific PP1 phosphatase com- } \\
\text { plexes, induces eIF2 phosphorylation }\end{array}$ \\
\hline Sal003 & $-/ /-$ & $-/ /-$ & I & $-/ /-$ \\
\hline Okadaic acid & $\begin{array}{l}\text { polyketine derivative } \\
\text { of C38-fatty acid }\end{array}$ & PP2A & I & $\begin{array}{l}\text { inhibits PP2A phosphatase, induces eIF2 } \\
\text { phosphorylation }\end{array}$ \\
\hline ISRIB & cyclohexylacetamide & eIF2B & I & $\begin{array}{l}\text { modulates eIF2B activity, prevents translation } \\
\text { inhibition }\end{array}$ \\
\hline Myriaporone 3/4 & $\begin{array}{l}\text { polyketide, tedanolide } \\
\text { analogue (see Table 1) }\end{array}$ & eEF2K? & $\mathrm{E}$ & induces eEF2 phosphorylation \\
\hline Nelfinavir/viracept & & $-/ /-$ & $\mathrm{E}$ & $-/ /-$ \\
\hline NH125 & $\begin{array}{l}\text { methylimidazolium } \\
\text { iodide }\end{array}$ & $-/ /-$ & $\mathrm{E}$ & $-/ /-$ \\
\hline A-484954 & pyrimidine-6-carboxamide & eEF2K & $\mathrm{E}$ & eEF2K inhibitor, prevents translation inhibition \\
\hline
\end{tabular}

Note. For letter codes and designations, see Table 1. 
(Ras/ERK/RSK and p38MAPK/Mnk1/2), which share some components with the PI3K/Akt/mTOR pathway $[253,254]$. Although MAPK signaling regulates the activity of some general translation factors, such as eIF4E, eIF4B, and eEF2, its effects on the cell functions are too broad; besides, there is no full understanding of how these cascades affect protein synthesis in general.

Modulators of eIF2 phosphorylation. Protein kinases phosphorylating the initiation factor eIF2 are much more specific. Mammals have four such kinases: GCN2, HRI, PERK, and PKR [265, 266]. eIF2 delivers the initiator Met-tRNA $A_{i}$ to the P-site of the $40 \mathrm{~S}$ subunit and provides scanning and AUG selection [5]. It is a key factor necessary for all eukaryotic mRNAs, except extremely rare cases when the start codon is positioned into the P-site without scanning (discussed in [267]). Phosphorylation of the eIF2 $\alpha$-subunit prevents protein dissociation from the inactive complex with eIF2B (guanine nucleotide exchange factor) and thus removes it form the active pool. Until recently, it had been believed that eIF2 is the only substrate for these four kinases; now we know that this is not entirely true [265, 268]. Nevertheless, there is no doubt that the main function of these kinases is regulation of protein synthesis. Therefore, in this section, we will discuss compounds modulating their activity.

BTdCPU and other $\mathrm{N}, \mathrm{N}^{\prime}$-diaryl urea derivatives are specific HRI activators (figure, s.2), which are also considered as promising antitumor drugs [269]. CCT020312 and MK-28 are pharmacological activators of PERK (figure, s.1) and can be potentially used in the treatment of neuropathies [270, 271]. Specific activators of GCN2 kinase (figure, s.3) have not yet been sufficiently studied; however, recent screening identified two candidates small molecules dabrafenib and MK1775 [264]. Interestingly, their addition to the human cells results in the suppression of the 5'-TOP mRNA translation, strongly resembling the effect of mTOR inhibitors (see above). Although the underlying mechanism has not been elucidated, earlier studies suggest a link between GCN2 and 5'TOP mRNA, mediated by TIA-1/TIAR proteins [272].

Another possibility to dramatically increase the level of eIF2 phosphorylation is inhibition of the eIF2-specific phosphatase complexes. Thus, salubrinal and its watersoluble derivative Sal003 inhibit protein synthesis by inactivating stress-inducible GADD34/PP1 and constitutively active CReP/PP1 complexes (figure, p.4) $[273,274]$. An increase in the eIF2 phosphorylation has also been reported when the cells were treated with okadaic acid, an inhibitor of PP2A phosphatase [275]; however, it is unclear if this effect was specific, as eIF2 $\alpha$ is most likely a substrate of PP1 rather than PP2A [276]. Nevertheless, both phosphatases play an important role in the translational control [277] and can be promising targets in the inhibition of protein synthesis.

Not only activators, but also many suppressors of the four kinases have been identified. They, however, have little or no effect on the protein synthesis level in living cell under normal conditions. At the same time, they prevent a decline in the translation under stress conditions. Since the transient translational block is an important part of the stress response, its disruption may have detrimental consequences for the stressed cell. Although these specific effects are important in the antiviral therapy, treatment of neurological disorders, and for promoting the effects of tumor chemotherapeutic drugs in oncology, they are beyond the scope of our review. Those interested in this topic can be referred to the review by Joshi et al. [268].

Nevertheless, we would like to mention the small molecule trans-ISRIB, which has a very unusual mechanism of action [278]. It binds to eIF2B and, up to certain limits, maintains its GDP/GTP-exchanging activity toward phosphorylated eIF2 (see details in [279]). As protein synthesis in the brain is necessary for the shortterm memory consolidation into the long-term memory, ISRIB can promote memory and enhance cognitive abilities in animals [278].

When discussing the inhibitory effect of eIF2 phosphorylation, we should also mention several chemicals that are often used by researchers for its indirect induction. These include tunicamycin (inhibitor of protein glycosylation causing endoplasmic reticulum stress), thapsigargin (inducer of $\mathrm{Ca}^{2+}$ release from the intracellular stores), and dithiothreitol (a thiol reducing agent, which triggers unfolded protein response, or UPR). All of them indirectly activate PERK. Other widely used chemicals are sodium arsenite (selectively targets $\mathrm{SH}$-groups in some proteins and triggers HRI activation), nonspecific oxidants such as hydrogen peroxide (also probably induces HRI), long double-stranded RNAs (PKR activators), some of the already mentioned amino acids analog, and ARSase inhibitors (indirectly activate GCN2). eIF2 phosphorylation is also induced by various blockers of the mitochondrial respiratory chain, ATP synthase, and glycolysis (e.g., myxothiazole, 2-deoxyglucose, oligomycin) and other inhibitors of cell energy metabolism. However, we will not discuss them in detail, since their action is nonspecific, while translation inhibition is only one of the components of the integrated stress response (ISR) that is triggered in cells by the action of stress factors [265, 266].

Inducers of eEF2 phosphorylation. The eEF2 elongation factor is inhibited by phosphorylation. Its activity is controlled by several kinases, but the main one is the specialized kinase eEF2K. Being a substrate of S6K and $\mathrm{mTOR}$, it is negatively regulated by the PI3K/Akt/mTOR cascade. When this cascade is suppressed, eEF2K is activated, while eEF2 is partially suppressed [253]. eEF2K inhibitors produce no noticeable effect on the cells under normal conditions (see [280]), whereas eEF2K activators can significantly reduce the efficiency of translation (figure, s.8). For example, the polyketide myriaporone $3 / 4$, which resembles the above-described ribosome inhibitors 
tedanolide and 13-deoxytedanolide [90], induces eEF2 phosphorylation [92] and thus negatively affects translation [91]. The antiviral drug nelfinavir [281] and compound NH125 (previously mistakenly thought to be an eEF2K inhibitor) have the same effect, although in the latter case, its association with eEF2K is not obvious [269, 282]. Modulators of the eEF2K activity are gaining an increasing attention of researchers due to the emerging role of this kinase in the development of depression, epilepsy, and neurodegenerative disorders [283].

AMPK is another kinase involved in the regulation of protein biosynthesis that should be mentioned in the context of eEF2 phosphorylation. It is a sensor of cell energy status and, when activated, contributes to the reduction of the elongation rate by signaling to eEF2K and phosphorylation of eEF2 [253]. There are many small molecules activating AMPK (figure, s.9) either indirectly via ATP depletion (e.g., 2-deoxyglucose, oligomycin, and the antidiabetic drug metformin) or directly. The latter include A-769622, benzimidazole derivative 991, and the most famous AMPK activator AICAR used by unscrupulous athletes for doping [284]. All these compounds eventually induce eEF2 phosphorylation, thereby decreasing the translation efficiency (discussed in detail in [285]). Needless to say, similar to the effects of inhibitors of the mTOR pathway (which shares some substrates with AMPK), the effects of AMPK activators on the cells are broad and not limited to the suppression of protein synthesis [254].

\section{RIBOTOXIC STRESS AND TRANSLATION- RELATED STRESS RESPONSES}

When studying the effects of translation inhibitors, one cannot ignore the response that occurs in cells upon partial or complete cessation of protein synthesis. Eukaryotes have several mechanisms that monitor the status of the general translational activity, including availability of amino acids, fidelity of the co-translational folding, and correct addressing of protein products. They are also involved in the translation quality control of individual transcripts by each ribosome [6,286]. At the end of the last century, it was shown that mammalian cells exposed to anisomycin or some other elongation inhibitors activate a special program called the ribotoxic stress response [287]. Interestingly, despite the same level of translation suppression, some inhibitors (anisomycin, deoxynivalenol) trigger a significant activation of the $\mathrm{JNK} / \mathrm{p} 38 \mathrm{MAPK}$ signaling pathway, leading to the rRNA cleavage and cell death, while others (for example, pactamycin) completely lack this ability [287-290]. It was further revealed that even chemically similar substances with the same mechanism of action might differ fundamentally in the stress level they cause. For example, diacetylanisomycin, a close derivative of anisomycin, does not activate the stress response at all [288]. Trichothecene mycotoxins with different side radicals vary dramatically in the ability to induce the response [288, 291, 292], although all of them inhibit the PTC. Theopederin, onnamide A, and 13-deoxytedanolide bind to different sites on the ribosome and inhibit translocation; however, they activate ribotoxic stress similarly to anisomycin [86, 293]. On the other hand, the translocation inhibitor cycloheximide is a relatively weak stress inducer [287, 294], while lactimidomycin (another glutarimide) strongly activates p38MAPK [294]. Cytotrienin A, while targeting eEF1A, also causes severe ribotoxic stress, [295], as well as some aminoglycosides, the ototoxicity of which may be associated, in particular, with the induction of this type of stress [296].

Until recently, the mechanism for the induction of the ribotoxic stress response had remained a mystery, although the intermediate components of the cascade JNK and p38MAPK kinases - were identified in the very first study on this topic [287]. Later, PKR and HCK kinases were also named as candidates for the mediators or primary inducers [287-290]. Recently, it was found that some elongation inhibitors, normally inducing the ribotoxic stress response, fail to trigger it when used in higher concentrations [67], suggesting that this phenomenon is based on the activation of certain signaling cascades by the two or three colliding ribosomes. When elongation is partially blocked by a drug, these collisions occur much more frequently, resulting in the induction of generalized cell response. However, if all ribosomes are arrested simultaneously, such collisions become impossible. This hypothesis was brilliantly confirmed in a recent study by the R. Green group [67]. The authors showed that the collided ribosomes orchestrate three different molecular pathways that have been previously considered independent. In the case of a single collision, the mechanisms of ribosomal quality control (RQC) are induced [6, 286], leading to the disassembly of the stalled elongation complex without triggering the general response. As the number of such events increases (for example, during amino acid starvation), the binding of GCN1 and GCN20 proteins and the MAP3K cascade kinase ZAK to the colliding ribosomes activates GCN2 kinase, which phosphorylates eIF2 (see above). If the number of collision sharply increases (e.g., upon antibiotic treatment or exposure to ultraviolet radiation), ribosome-bound ZAK activates the JNK/p38MAPK signaling cascade and triggers the ribotoxic stress response [67, 294]. Indeed, it has long been known that this type of stress can be partially suppressed by the small-molecule inhibitors DHP-2, sorafenib, and nilotinib, which target ZAK [297-299]. These findings might also explain recent observation that the cell response to ARSase inhibitors (see above) is dissimilar to that induced by regular amino acid starvation [252]. The response to deacylated tRNA and frequent ribosome collisions is based on the activation of GCN2 
and/or MAPK stress kinases and occurs via different scenario than the starvation response, which "senses" amino acids availability through a cascade of interactions involving mTOR kinase [300].

\section{CONCLUSION}

Protein biosynthesis is one of the major metabolic processes that is crucial for maintaining all body functions. In actively proliferating cells, it consumes a significant portion of their energy and resources. Disruption of protein biosynthesis leads to an inevitable arrest of cell division and death. It is not surprising that translation is the "Achilles heel" of tumor cells and actively propagating viruses [136, 203, 259, 301, 302]. The development of small-molecule inhibitors for manipulating protein synthesis is very important in the anticancer and immunosuppressive therapy, treatment of hereditary, viral and fungal diseases, neurology, parasitology and geriatrics, solving problems of lifespan extension, as well as agriculture, veterinary, and other fields $[8,27,132,148,151$, $155,214,259,261,301,302]$. However, their clinical use is still limited due to the cytotoxicity-related side effects. Rapid development of high-throughput screening techniques [303], as well as machine learning [304] and computer modeling, in combination with modern methods of structural analysis and chemical synthesis [84, 237-239] has given hope for rapid progress in the development of new drug derivatives with improved therapeutic properties. The impact of systems biology approaches on the search for and characterization of new inhibitors will also undoubtedly increase. For example, comparison of transcription patterns helps to determine the mechanisms of action of newly discovered and previously known compounds [39, 205]. In our opinion, another underestimated approach is the combination therapy with different types of inhibitors [164, 165]. Finally, due to the variety of action mechanisms, many of the described compounds can be widely used not only in practice, but also in basic research to study the principles of protein synthesis and translational control $[4,16,24,82,127,134$, 267, 305].

In this review, we attempted to describe the major classes of small-molecule inhibitors of eukaryotic translation. However, the number of currently known drugs with this activity, even those with characterized mechanism of action, reaches several hundred, so it was impossible to review all of them in one article. Besides, this list is constantly growing. Therefore, we have developed a constantly updated Eukaryotic Protein Synthesis Inhibiting Compounds (EuPSIC) database that contains additional information that can be used to facilitate machine processing, such as PubChem numbers and literature references with PubMed IDs. The database can be found at http://eupsic.belozersky.msu.ru.
Funding. This work was supported by the Russian Science Foundation (project no. 18-14-00291).

Acknowledgments. The authors are grateful to Maxim Lashkevich for his help in preparing the tables and administration of the computer server of the Belozersky Institute of Physico-Chemical Biology, Moscow State University, for the database hosting.

Ethics declarations. The authors declare no conflicts of interest. This article does not describe any research involving humans or animals performed by any of the authors.

Open access. This article is distributed under the terms of the Creative Commons Attribution 4.0 International License (http://creativecommons.org/licenses/by/4.0/), which permits unrestricted use, distribution, and reproduction in any medium, provided you give appropriate credit to the original author(s) and the source, provide a link to the Creative Commons license, and indicate if changes were made.

\section{REFERENCES}

1. Pelletier, J., and Sonenberg, N. (2019) The organizing principles of eukaryotic ribosome recruitment, Annu. Rev. Biochem., 88, 307-335, doi: 10.1146/annurev-biochem013118-111042.

2. Yusupova, G., and Yusupov, M. (2014) High-resolution structure of the eukaryotic $80 \mathrm{~S}$ ribosome, Annu. Rev. Biochem., 83, 467-486, doi: 10.1146/annurev-biochem060713-035445.

3. Weisser, M., and Ban, N. (2019) Extensions, extra factors, and extreme complexity: ribosomal structures provide insights into eukaryotic translation, Cold Spring Harb. Perspect. Biol., 11, a032367, doi: 10.1101/cshperspect. a032367.

4. Andreev, D. E., O’Connor, P. B., Loughran, G., Dmitriev, S. E., Baranov, P. V., and Shatsky, I. N. (2017) Insights into the mechanisms of eukaryotic translation gained with ribosome profiling, Nucleic Acids Res., 45, 513-526, doi: 10.1093/nar/gkw1190.

5. Hinnebusch, A. G. (2017) Structural insights into the mechanism of scanning and start codon recognition in eukaryotic translation initiation, Trends Biochem. Sci., 42, 589-611, doi: 10.1016/j.tibs.2017.03.004.

6. Schuller, A. P., and Green, R. (2018) Roadblocks and resolutions in eukaryotic translation, Nat. Rev. Mol. Cell Biol., 19, 526-541, doi: 10.1038/s41580-018-0011-4.

7. Wilson, D. N. (2009) The A-Z of bacterial translation inhibitors, Crit. Rev. Biochem. Mol. Biol., 44, 393-433, doi: 10.3109/10409230903307311.

8. Lin, J., Zhou, D., Steitz, T. A., Polikanov, Y. S., and Gagnon, M. G. (2018) Ribosome-targeting antibiotics: modes of action, mechanisms of resistance, and implications for drug design, Annu. Rev. Biochem., 87, 451-478, doi: 10.1146/annurev-biochem-062917-011942.

9. Yusupova, G., and Yusupov, M. (2017) Crystal structure of eukaryotic ribosome and its complexes with inhibitors, Philos. Trans. R. Soc. London B Biol. Sci., 372, 20160184, doi: 10.1098/rstb.2016.0184. 
10. Vazquez, D. (1979) Inhibitors of protein biosynthesis, Mol. Biol. Biochem. Biophys., 30, 1-312, doi: 10.1007/978-3642-81309-2.

11. Pestka, S. (1971) Inhibitors of ribosome functions, Annu. Rev. Microbiol., 25, 487-562, doi: 10.1146/annurev.mi.25. 100171.002415.

12. Pestka, S. (1974) The use of inhibitors in studies on protein synthesis, Methods Enzymol., 30, 261-282, doi: 10.1016/ 0076-6879(74)30030-4.

13. Jiménez, A., and Vázquez, D. (1983) Novel Inhibitors of Translation in Eukaryotic Systems, in Modes and Mechanisms of Microbial Growth Inhibitors (Hahn, F. E., ed.) Springer Berlin Heidelberg, Berlin, Heidelberg, pp. 248-254.

14. Garreau de Loubresse, N., Prokhorova, I., Holtkamp, W., Rodnina, M. V., Yusupova, G., and Yusupov, M. (2014) Structural basis for the inhibition of the eukaryotic ribosome, Nature, 513, 517-522, doi: 10.1038/nature13737.

15. Barbacid, M., and Vazquez, D. (1974) (3H)anisomycin binding to eukaryotic ribosomes, J. Mol. Biol., 84, 603-623, doi: 10.1016/0022-2836(74)90119-3.

16. Wu, C. C., Zinshteyn, B., Wehner, K. A., and Green, R. (2019) High-resolution ribosome profiling defines discrete ribosome elongation states and translational regulation during cellular stress, Mol. Cell, 73, 959-970 e955, doi: 10.1016/j.molcel.2018.12.009.

17. Barbacid, M., Fresno, M., and Vazquez, D. (1975) Inhibitors of polypeptide elongation on yeast polysomes, J. Antibiot. (Tokyo), 28, 453-462, doi: 10.7164/antibiotics. 28.453.

18. Fresno, M., Carrasco, L., and Vazquez, D. (1976) Initiation of the polypeptide chain by reticulocyte cell-free systems. Survey of different inhibitors of translation, Eur. J. Biochem., 68, 355-364, doi: 10.1111/j.1432-1033.1976.tb10822.x.

19. Cundliffe, E., Cannon, M., and Davies, J. (1974) Mechanism of inhibition of eukaryotic protein synthesis by trichothecene fungal toxins, Proc. Natl. Acad. Sci. USA, 71, 30-34, doi: 10.1073/pnas.71.1.30.

20. Pellegrino, S., Meyer, M., Zorbas, C., Bouchta, S. A., Saraf, K., et al. (2018) The amaryllidaceae alkaloid haemanthamine binds the eukaryotic ribosome to repress cancer cell growth, Structure, 26, 416-425 e414, doi: 10.1016/ j.str.2018.01.009.

21. Baez, A., and Vazquez, D. (1978) Binding of [3H]narciclasine to eukaryotic ribosomes. A study on a structure-activity relationship, Biochim. Biophys. Acta, 518, 95-103, doi: 10.1016/0005-2787(78)90119-3.

22. Jimenez, A., Santos, A., Alonso, G., and Vazquez, D. (1976) Inhibitors of protein synthesis in eukarytic cells. Comparative effects of some amaryllidaceae alkaloids, Biochim. Biophys. Acta, 425, 342-348, doi: 10.1016/00052787(76)90261-6.

23. Fresno, M., Jimenez, A., and Vazquez, D. (1977) Inhibition of translation in eukaryotic systems by harringtonine, Eur. J. Biochem., 72, 323-330, doi: 10.1111/j.14321033.1977.tb11256.x.

24. Ingolia, N. T., Lareau, L. F., and Weissman, J. S. (2011) Ribosome profiling of mouse embryonic stem cells reveals the complexity and dynamics of mammalian proteomes, Cell, 147, 789-802, doi: 10.1016/j.cell.2011.10.002.

25. Tscherne, J. S., and Pestka, S. (1975) Inhibition of protein synthesis in intact HeLa cells, Antimicrob. Agents Chemother., 8, 479-487, doi: 10.1128/aac.8.4.479.
26. Gurel, G., Blaha, G., Moore, P. B., and Steitz, T. A. (2009) U2504 determines the species specificity of the A-site cleft antibiotics: the structures of tiamulin, homoharringtonine, and bruceantin bound to the ribosome, J. Mol. Biol., 389, 146-156, doi: 10.1016/j.jmb.2009.04.005.

27. Winer, E. S., and DeAngelo, D. J. (2018) A review of omacetaxine: a chronic myeloid leukemia treatment resurrected, Oncol. Ther., 6, 9-20, doi: 10.1007/s40487-018-0058-6.

28. Wang, Z., and Yang, L. (2020) Turning the tide: natural products and natural-product-inspired chemicals as potential counters to SARS-CoV-2 infection, Front. Pharmacol., 11, 1013, doi: 10.3389/fphar.2020.01013.

29. Huang, M. T. (1975) Harringtonine, an inhibitor of initiation of protein biosynthesis, Mol. Pharmacol., 11, 511-519.

30. Carter, C. J., and Cannon, M. (1977) Structural requirements for the inhibitory action of 12,13-epoxytrichothecenes on protein synthesis in eukaryotes, Biochem. J., 166, 399-409, doi: 10.1042/bj1660399.

31. Cannon, M., Jimenez, A., and Vazquez, D. (1976) Competition between trichodermin and several other sesquiterpene antibiotics for binding to their receptor site(s) on eukaryotic ribosomes, Biochem. J., 160, 137-145, doi: 10.1042/bj1600137.

32. Ehrlich, K. C., and Daigle, K. W. (1987) Protein synthesis inhibition by 8-oxo-12,13-epoxytrichothecenes, Biochim. Biophys. Acta, 923, 206-213, doi: 10.1016/0304-4165(87)90005-5.

33. Carter, C. J., and Cannon, M. (1978) Inhibition of eukaryotic ribosomal function by the sesquiterpenoid antibiotic fusarenon-X, Eur. J. Biochem., 84, 103-111, doi: 10.1111/ j.1432-1033.1978.tb12146.x.

34. Schneider-Poetsch, T., Ju, J., Eyler, D. E., Dang, Y., Bhat, S., et al. (2010) Inhibition of eukaryotic translation elongation by cycloheximide and lactimidomycin, Nat. Chem. Biol., 6, 209-217, doi: 10.1038/nchembio.304.

35. Chan, J., Khan, S. N., Harvey, I., Merrick, W., and Pelletier, J. (2004) Eukaryotic protein synthesis inhibitors identified by comparison of cytotoxicity profiles, $R N A, \mathbf{1 0}$, 528-543, doi: 10.1261/rna.5200204.

36. McClary, B., Zinshteyn, B., Meyer, M., Jouanneau, M., Pellegrino, S., et al. (2017) Inhibition of eukaryotic translation by the antitumor natural product agelastatin A, Cell Chem. Biol., 24, 605-613 e605, doi: 10.1016/j.chembiol. 2017.04.006.

37. Cuendet, M., and Pezzuto, J. M. (2004) Antitumor activity of bruceantin: an old drug with new promise, J. Nat. Prod., 67, 269-272, doi: 10.1021/np030304+.

38. Fresno, M., Gonzales, A., Vazquez, D., and Jimenez, A. (1978) Bruceantin, a novel inhibitor of peptide bond formation, Biochim. Biophys. Acta, 518, 104-112, doi: 10.1016/0005-2787(78)90120-x.

39. Zhang, L. L., Guo, J., Jiang, X. M., Chen, X. P., Wang, Y. T., Li, A., Lin, L. G., Li, H., and Lu, J. J. (2020) Identification of nagilactone $\mathrm{E}$ as a protein synthesis inhibitor with anticancer activity, Acta pharmacol. Sin., 41, 698-705, doi: 10.1038/s41401-019-0332-7.

40. Polikanov, Y. S., Starosta, A. L., Juette, M. F., Altman, R. B., Terry, D. S., et al. (2015) Distinct tRNA accommodation intermediates observed on the ribosome with the antibiotics hygromycin A and A201A, Mol. Cell, 58, 832844, doi: 10.1016/j.molcel.2015.04.014.

41. Amunts, A., Fiedorczuk, K., Truong, T. T., Chandler, J., Greenberg, E. P., and Ramakrishnan, V. (2015) Bactobolin 
A binds to a site on the $70 \mathrm{~S}$ ribosome distinct from previously seen antibiotics, J. Mol. Biol., 427, 753-755, doi: 10.1016/j.jmb.2014.12.018.

42. Hori, M., Suzukake, K., Ishikawa, C., Asakura, H., and Umezawa, H. (1981) Biochemical studies on bactobolin in relation to actinobolin, J. Antibiot. (Tokyo), 34, 465-468, doi: 10.7164/antibiotics.34.465.

43. Cerna, J., Rychlik, I., and Lichtenthaler, F. W. (1973) The effect of the aminoacyl-4-aminohexosyl-cytosine group of antibiotics on ribosomal peptidyl transferase, FEBS Lett., 30, 147-150, doi: 10.1016/0014-5793(73)80639-8.

44. Hansen, J. L., Moore, P. B., and Steitz, T. A. (2003) Structures of five antibiotics bound at the peptidyl transferase center of the large ribosomal subunit, J. Mol. Biol., 330, 1061-1075, doi: 10.1016/s0022-2836(03)00668-5.

45. Svidritskiy, E., Ling, C., Ermolenko, D. N., and Korostelev, A. A. (2013) Blasticidin S inhibits translation by trapping deformed tRNA on the ribosome, Proc. Natl. Acad. Sci. USA, 110, 12283-12288, doi: 10.1073/pnas. 1304922110.

46. Lashkevich, K. A., Shlyk, V. I., Kushchenko, A. S., Gladyshev, V. N., Alkalaeva, E. Z., and Dmitriev, S. E. (2020) CTELS: a cell-free system for the analysis of translation termination rate, Biomolecules, 10, 911, doi: 10.3390/biom10060911.

47. Gonzalez, A., Vazquez, D., and Jimenez, A. (1979) Inhibition of translation in bacterial and eukaryotic systems by the antibiotic anthelmycin (hikizimycin), Biochim. Biophys. Acta, 561, 403-409, doi: 10.1016/00052787(79)90148-5.

48. Sikorski, M. M., Cerna, J., Rychlik, I., and Legocki, A. B. (1977) Peptidyl transferase activity in wheat germ ribosomes. Effect of some antibiotics, Biochim. Biophys. Acta, 475, 123-130, doi: 10.1016/0005-2787(77)90346-x.

49. Leviev, I. G., Rodriguez-Fonseca, C., Phan, H., Garrett, R. A., Heilek, G., Noller, H. F., and Mankin, A. S. (1994) A conserved secondary structural motif in 23S rRNA defines the site of interaction of amicetin, a universal inhibitor of peptide bond formation, EMBO J., 13, 1682-1686.

50. Dmitriev, S. E., Akulich, K. A., Andreev, D. E., Terenin, I. M., and Shatsky, I. N. (2013) The peculiar mode of translation elongation inhibition by antitumor drug harringtonin, FEBS J., 280, 51-51, doi: 10.1111/febs.12340.

51. Akulich, K. A., Sinitcyn, P. G., Lomakin, I. B., Andreev, D. E., Terenin, I. M., Smirnova, V. V., Mironov, A. A., Shatsky, I. N., and Dmitriev, S. E. (2017) Peptidyl transferase inhibitors arrest the ribosome at specific amino acid codons: insights from an integrated approach, FEBS J., 284, 296-296, doi: 10.1111/febs. 14174 .

52. Michel, A. M., Andreev, D. E., and Baranov, P. V. (2014) Computational approach for calculating the probability of eukaryotic translation initiation from ribo-seq data that takes into account leaky scanning, BMC Bioinform., 15, 380, doi: 10.1186/s12859-014-0380-4.

53. Marks, J., Kannan, K., Roncase, E. J., Klepacki, D., Kefi, A., Orelle, C., Vazquez-Laslop, N., and Mankin, A. S. (2016) Context-specific inhibition of translation by ribosomal antibiotics targeting the peptidyl transferase center, Proc. Natl. Acad. Sci. USA, 113, 12150-12155, doi: $10.1073 /$ pnas. 1613055113 .

54. Vazquez-Laslop, N., and Mankin, A. S. (2018) Contextspecific action of ribosomal antibiotics, Ann. Rev.
Microbiol., 72, 185-207, doi: 10.1146/annurev-micro090817-062329.

55. Kannan, K., Kanabar, P., Schryer, D., Florin, T., Oh, E., Bahroos, N., Tenson, T., Weissman, J. S., and Mankin, A. S. (2014) The general mode of translation inhibition by macrolide antibiotics, Proc. Natl. Acad. Sci. USA, 111, 15958-15963, doi: 10.1073/pnas.1417334111.

56. Mankin, A. S. (2008) Macrolide myths, Curr. Opin. Microbiol., 11, 414-421, doi: 10.1016/j.mib.2008.08.003.

57. Vazquez-Laslop, N., Thum, C., and Mankin, A. S. (2008) Molecular mechanism of drug-dependent ribosome stalling, Mol. Cell, 30, 190-202, doi: 10.1016/j.molcel.2008.02.026.

58. Tu, D., Blaha, G., Moore, P. B., and Steitz, T. A. (2005) Structures of MLSBK antibiotics bound to mutated large ribosomal subunits provide a structural explanation for resistance, Cell, 121, 257-270, doi: 10.1016/j.cell.2005.02. 005.

59. Hansen, J. L., Ippolito, J. A., Ban, N., Nissen, P., Moore, P. B., and Steitz, T. A. (2002) The structures of four macrolide antibiotics bound to the large ribosomal subunit, Mol. Cell, 10, 117-128, doi: 10.1016/s1097-2765(02)00570-1.

60. Gurel, G., Blaha, G., Steitz, T. A., and Moore, P. B. (2009) Structures of triacetyloleandomycin and mycalamide A bind to the large ribosomal subunit of Haloarcula marismortui, Antimicrob. Agents Chemother., 53, 5010-5014, doi: 10.1128/AAC.00817-09.

61. Nishimura, S., Matsunaga, S., Yoshida, M., Hirota, H., Yokoyama, S., and Fusetani, N. (2005) 13-Deoxytedanolide, a marine sponge-derived antitumor macrolide, binds to the 60S large ribosomal subunit, Bioorg. Med. Chem., 13, 449-454, doi: 10.1016/j.bmc.2004.10.012.

62. Lintner, N. G., McClure, K. F., Petersen, D., Londregan, A. T., Piotrowski, D. W., et al. (2017) Selective stalling of human translation through small-molecule engagement of the ribosome nascent chain, PLoS Biol., 15, e2001882, doi: 10.1371/journal.pbio.2001882.

63. Liaud, N., Horlbeck, M. A., Gilbert, L. A., Gjoni, K., Weissman, J. S., and Cate, J. H. D. (2019) Cellular response to small molecules that selectively stall protein synthesis by the ribosome, PLoS Genet., 15, e1008057, doi: 10.1371/journal.pgen.1008057.

64. Li, W., Ward, F. R., McClure, K. F., Chang, S. T., Montabana, E., Liras, S., Dullea, R. G., and Cate, J. H. D. (2019) Structural basis for selective stalling of human ribosome nascent chain complexes by a drug-like molecule, Nat. Struct. Mol. Biol., 26, 501-509, doi: 10.1038/s41594019-0236-8.

65. Osterman, I. A., Wieland, M., Maviza, T. P., Lashkevich, K. A., Lukianov, D. A., et al. (2020) Tetracenomycin X inhibits translation by binding within the ribosomal exit tunnel, Nat. Chem. Biol., 16, 1071-1077, doi: 10.1038/ s41589-020-0578-X.

66. Mortison, J. D., Schenone, M., Myers, J. A., Zhang, Z., Chen, L., et al. (2018) Tetracyclines modify translation by targeting key human rRNA substructures, Cell Chem. Biol., 25, 1506-1518.e13, doi: 10.1016/j.chembiol.2018.09.010.

67. Wu, C. C., Peterson, A., Zinshteyn, B., Regot, S., and Green, R. (2020) Ribosome collisions trigger general stress responses to regulate cell fate, Cell, 182, 404-416 e414, doi: 10.1016/j.cell.2020.06.006.

68. Jenner, L., Starosta, A. L., Terry, D. S., Mikolajka, A., Filonava, L., et al. (2013) Structural basis for potent 
inhibitory activity of the antibiotic tigecycline during protein synthesis, Proc. Natl. Acad. Sci. USA, 110, 3812-3816, doi: 10.1073/pnas.1216691110.

69. Solis, G. M., Kardakaris, R., Valentine, E. R., Bar-Peled, L., Chen, A. L., et al. (2018) Translation attenuation by minocycline enhances longevity and proteostasis in old post-stress-responsive organisms, eLife, 7, doi: 10.7554/ eLife.40314.

70. Garrido-Mesa, N., Zarzuelo, A., and Galvez, J. (2013) Minocycline: far beyond an antibiotic, Br. J. Pharmacol., 169, 337-352, doi: 10.1111/bph.12139.

71. Obrig, T. G., Culp, W. J., McKeehan, W. L., and Hardesty, B. (1971) The mechanism by which cycloheximide and related glutarimide antibiotics inhibit peptide synthesis on reticulocyte ribosomes, J. Biol. Chem., 246, 174-181.

72. Klinge, S., Voigts-Hoffmann, F., Leibundgut, M., Arpagaus, S., and Ban, N. (2011) Crystal structure of the eukaryotic 60S ribosomal subunit in complex with initiation factor 6 , Science, 334, 941-948, doi: 10.1126/science.1211204.

73. Dmitriev, S. E., Pisarev, A. V., Rubtsova, M. P., Dunaevsky, Y. E., and Shatsky, I. N. (2003) Conversion of 48S translation preinitiation complexes into $80 \mathrm{~S}$ initiation complexes as revealed by toeprinting, FEBS Lett., 533, 99-104, doi: 10.1016/s0014-5793(02)03776-6.

74. Budkevich, T., Giesebrecht, J., Altman, R. B., Munro, J. B., Mielke, T., Nierhaus, K. H., Blanchard, S. C., and Spahn, C. M. (2011) Structure and dynamics of the mammalian ribosomal pretranslocation complex, Mol. Cell, 44, 214-224, doi: 10.1016/j.molcel.2011.07.040.

75. Myasnikov, A. G., Kundhavai Natchiar, S., Nebout, M., Hazemann, I., Imbert, V., Khatter, H., Peyron, J. F., and Klaholz, B. P. (2016) Structure-function insights reveal the human ribosome as a cancer target for antibiotics, Nat. Commun., 7, 12856, doi: 10.1038/ncomms12856.

76. Pestova, T. V., and Hellen, C. U. (2003) Translation elongation after assembly of ribosomes on the Cricket paralysis virus internal ribosomal entry site without initiation factors or initiator tRNA, Gen. Dev., 17, 181-186, doi: 10.1101/ gad.1040803.

77. Iwasaki, S., and Ingolia, N. T. (2017) The growing toolbox for protein synthesis studies, Trends Biochem. Sci., 42, 612624, doi: 10.1016/j.tibs.2017.05.004.

78. Park, Y., Koga, Y., Su, C., Waterbury, A. L., Johnny, C. L., and Liau, B. B. (2019) Versatile synthetic route to cycloheximide and analogues that potently inhibit translation elongation, Angew. Chem. Int. Ed. Engl., 58, 5387-5391, doi: 10.1002/anie.201901386.

79. Landsman, D., Srikantha, T., and Bustin, M. (1988) Single copy gene for the chicken non-histone chromosomal protein HMG-17, J. Biol. Chem., 263, 3917-3923.

80. Zhang, D., Yi, W., Ge, H., Zhang, Z., and Wu, B. (2019) Bioactive streptoglutarimides A-J from the marine-derived Streptomyces sp. ZZ741, J. Nat. Prod., 82, 2800-2808, doi: 10.1021/acs.jnatprod.9b00481.

81. Sugawara, K., Nishiyama, Y., Toda, S., Komiyama, N., Hatori, M., Moriyama, T., Sawada, Y., Kamei, H., Konishi, M., and Oki, T. (1992) Lactimidomycin, a new glutarimide group antibiotic. Production, isolation, structure and biological activity, J. Antibiot. (Tokyo), 45, 14331441, doi: 10.7164/antibiotics.45.1433.

82. Lee, S., Liu, B., Lee, S., Huang, S. X., Shen, B., and Qian, S. B. (2012) Global mapping of translation initiation sites in mammalian cells at single-nucleotide resolution, Proc. Natl. Acad. Sci. USA, 109, E2424-2432, doi: 10.1073/pnas. 1207846109.

83. Pellegrino, S., Meyer, M., Konst, Z. A., Holm, M., Voora, V. K., et al. (2019) Understanding the role of intermolecular interactions between lissoclimides and the eukaryotic ribosome, Nucleic Acids Res., 47, 3223-3232, doi: 10.1093/ nar/gkz053.

84. Konst, Z. A., Szklarski, A. R., Pellegrino, S., Michalak, S. E., Meyer, M., et al. (2017) Synthesis facilitates an understanding of the structural basis for translation inhibition by the lissoclimides, Nat. Chem., 9, 1140-1149, doi: 10.1038/ nchem. 2800 .

85. Robert, F., Gao, H. Q., Donia, M., Merrick, W. C., Hamann, M. T., and Pelletier, J. (2006) Chlorolissoclimides: new inhibitors of eukaryotic protein synthesis, $R N A$, 12, 717-725, doi: 10.1261/rna.2346806.

86. Lee, K. H., Nishimura, S., Matsunaga, S., Fusetani, N., Horinouchi, S., and Yoshida, M. (2005) Inhibition of protein synthesis and activation of stress-activated protein kinases by onnamide A and theopederin B, antitumor marine natural products, Cancer Sci., 96, 357-364, doi: 10.1111/j.1349-7006.2005.00055.x.

87. Brega, A., Falaschi, A., De Carli, L., and Pavan, M. (1968) Studies on the mechanism of action of pederine, J. Cell Biol., 36, 485-496, doi: 10.1083/jcb.36.3.485.

88. Jacobs-Lorena, M., Brega, A., and Baglioni, C. (1971) Inhibition of protein synthesis in reticulocytes by antibiotics. V. Mechanism of action of pederine, an inhibitor of initiation and elongation, Biochim. Biophys. Acta, 240, 263-272.

89. Schroeder, S. J., Blaha, G., Tirado-Rives, J., Steitz, T. A., and Moore, P. B. (2007) The structures of antibiotics bound to the E site region of the $50 \mathrm{~S}$ ribosomal subunit of Haloarcula marismortui: 13-deoxytedanolide and girodazole, J. Mol. Biol., 367, 1471-1479, doi: 10.1016/j.jmb.2007.01.081.

90. Taylor, R. E. (2008) Tedanolide and the evolution of polyketide inhibitors of eukaryotic protein synthesis, Nat. Prod. Rep., 25, 854-861, doi: 10.1039/b805700c.

91. Hines, J., Roy, M., Cheng, H., Agapakis, C. M., Taylor, R., and Crews, C. M. (2006) Myriaporone 3/4 structureactivity relationship studies define a pharmacophore targeting eukaryotic protein synthesis, Mol. Biosyst., 2, 371-379, doi: 10.1039/b602936a.

92. Muthukumar, Y., Roy, M., Raja, A., Taylor, R. E., and Sasse, F. (2013) The marine polyketide myriaporone 3/4 stalls translation by targeting the elongation phase, Chembiochem, 14, 260-264, doi: 10.1002/cbic.201200522.

93. Prokhorova, I. V., Akulich, K. A., Makeeva, D. S., Osterman, I. A., Skvortsov, D. A., et al. (2016) Amicoumacin A induces cancer cell death by targeting the eukaryotic ribosome, Sci. Rep., 6, 27720, doi: 10.1038/ srep27720.

94. Wong, W., Bai, X. C., Brown, A., Fernandez, I. S., Hanssen, E., Condron, M., Tan, Y. H., Baum, J., and Scheres, S. H. (2014) Cryo-EM structure of the Plasmodium falciparum 80 S ribosome bound to the antiprotozoan drug emetine, eLife, 3, doi: 10.7554/ eLife.03080.

95. Chang, S., and Wasmuth, J. J. (1983) Construction and characterization of Chinese hamster cell EmtA EmtB double mutants, Mol. Cell. Biol., 3, 761-772, doi: 10.1128/ mcb.3.5.761. 
96. Grant, P., Sanchez, L., and Jimenez, A. (1974) Cryptopleurine resistance: genetic locus for a $40 \mathrm{~S}$ ribosomal component in Saccharomyces cerevisiae, J. Bacteriol., 120, 1308-1314, doi: 10.1128/JB.120.3.1308-1314.1974.

97. Gupta, R. S., and Siminovitch, L. (1977) Mutants of CHO cells resistant to the protein synthesis inhibitors, cryptopleurine and tylocrebrine: genetic and biochemical evidence for common site of action of emetine, cryptopleurine, tylocrebine, and tubulosine, Biochemistry, 16, 3209-3214, doi: 10.1021/bi00633a026.

98. Bucher, K., and Skogerson, L. (1976) Cryptopleurine-an inhibitor of translocation, Biochemistry, 15, 4755-4759, doi: 10.1021/bi00667a001.

99. Carrasco, L., Jimenez, A., and Vazquez, D. (1976) Specific inhibition of translocation by tubulosine in eukaryotic polysomes, Eur. J. Biochem., 64, 1-5, doi: 10.1111/j.1432-1033.1976.tb10268.x.

100. Wang, Y., Wong, H. C., Gullen, E. A., Lam, W., Yang, X., Shi, Q., Lee, K. H., and Cheng, Y. C. (2012) Cryptopleurine analogs with modification of e ring exhibit different mechanism to rac-cryptopleurine and tylo-phorine, PLoS One, 7, e51138, doi: 10.1371/journal.pone. 0051138.

101. Donaldson, G. R., Atkinson, M. R., and Murray, A. W. (1968) Inhibition of protein synthesis in Ehrlich ascitestumour cells by the phenanthrene alkaloids tylophorine, tylocrebrine and cryptopleurine, Biochem. Biophys. Res. Commun., 31, 104-109, doi: 10.1016/0006-291x(68)90037-5.

102. Polikanov, Y. S., Osterman, I. A., Szal, T., Tashlitsky, V. N., Serebryakova, M. V., et al. (2014) Amicoumacin a inhibits translation by stabilizing mRNA interaction with the ribosome, Mol. Cell, 56, 531-540, doi: 10.1016/j.molcel.2014.09.020.

103. Brodersen, D. E., Clemons, W. M., Jr., Carter, A. P., Morgan-Warren, R. J., Wimberly, B. T., and Ramakrishnan, V. (2000) The structural basis for the action of the antibiotics tetracycline, pactamycin, and hygromycin B on the $30 \mathrm{~S}$ ribosomal subunit, Cell, 103, 1143-1154, doi: 10.1016/s0092-8674(00)00216-6.

104. Dinos, G., Wilson, D. N., Teraoka, Y., Szaflarski, W., Fucini, P., Kalpaxis, D., and Nierhaus, K. H. (2004) Dissecting the ribosomal inhibition mechanisms of edeine and pactamycin: the universally conserved residues G693 and C795 regulate P-site RNA binding, Mol. Cell, 13, 113124, doi: 10.1016/s1097-2765(04)00002-4.

105. Borovinskaya, M. A., Shoji, S., Fredrick, K., and Cate, J. H. (2008) Structural basis for hygromycin B inhibition of protein biosynthesis, $R N A, \mathbf{1 4}, 1590-1599$, doi: 10.1261/ rna.1076908.

106. Gonzalez, A., Jimenez, A., Vazquez, D., Davies, J. E., and Schindler, D. (1978) Studies on the mode of action of hygromycin B, an inhibitor of translocation in eukaryotes, Biochim. Biophys. Acta, 521, 459-469, doi: 10.1016/00052787(78)90287-3.

107. Misumi, M., Nishimura, T., Komai, T., and Tanaka, N. (1978) Interaction of kanamycin and related antibiotics with the large subunit of ribosomes and the inhibition of translocation, Biochem. Biophys. Res. Commun., 84, 358365, doi: 10.1016/0006-291x(78)90178-x.

108. Cabanas, M. J., Vazquez, D., and Modolell, J. (1978) Inhibition of ribosomal translocation by aminoglycoside antibiotics, Biochem. Biophys. Res. Commun., 83, 991-997, doi: 10.1016/0006-291x(78)91493-6.
109. Borovinskaya, M. A., Pai, R. D., Zhang, W., Schuwirth, B. S., Holton, J. M., et al. (2007) Structural basis for aminoglycoside inhibition of bacterial ribosome recycling, Nat. Struct. Mol. Biol., 14, 727-732, doi: 10.1038/nsmb1271.

110. Prokhorova, I., Altman, R. B., Djumagulov, M., Shrestha, J. P., Urzhumtsev, A., et al. (2017) Aminoglycoside interactions and impacts on the eukaryotic ribosome, Proc. Natl. Acad. Sci. USA, 114, E10899-E10908, doi: 10.1073/ pnas. 1715501114.

111. Krause, K. M., Serio, A. W., Kane, T. R., and Connolly, L. E. (2016) Aminoglycosides: an overview, Cold Spring Harb. Perspect. Med., 6, doi: 10.1101/cshperspect.a027029.

112. Wilhelm, J. M., Pettitt, S. E., and Jessop, J. J. (1978) Aminoglycoside antibiotics and eukaryotic protein synthesis: structure-function relationships in the stimulation of misreading with a wheat embryo system, Biochemistry, 17, 1143-1149, doi: 10.1021/bi00600a001.

113. Howard, M., Frizzell, R. A., and Bedwell, D. M. (1996) Aminoglycoside antibiotics restore CFTR function by overcoming premature stop mutations, Nat. Med., 2, 467469, doi: 10.1038/nm0496-467.

114. Kandasamy, J., Atia-Glikin, D., Shulman, E., Shapira, K., Shavit, M., Belakhov, V., and Baasov, T. (2012) Increased selectivity toward cytoplasmic versus mitochondrial ribosome confers improved efficiency of synthetic aminoglycosides in fixing damaged genes: a strategy for treatment of genetic diseases caused by nonsense mutations, J. Med. Chem., 55, 10630-10643, doi: 10.1021/ jm3012992.

115. Wangen, J. R., and Green, R. (2020) Stop codon context influences genome-wide stimulation of termination codon readthrough by aminoglycosides, eLife, 9, doi: 10.7554/ eLife.52611.

116. Kuang, L., Hashimoto, K., Huang, E. J., Gentry, M. S., and Zhu, H. (2020) Frontotemporal dementia non-sense mutation of progranulin rescued by aminoglycosides, Hum. Mol. Genet., 29, 624-634, doi: 10.1093/hmg/ddz280.

117. Sabbavarapu, N. M., Shavit, M., Degani, Y., Smolkin, B., Belakhov, V., and Baasov, T. (2016) Design of novel aminoglycoside derivatives with enhanced suppression of diseases-causing nonsense mutations, ACS Med. Chem. Lett., 7, 418-423, doi: 10.1021/acsmedchemlett.6b00006.

118. Shalev, M., and Baasov, T. (2014) When proteins start to make sense: fine-tuning aminoglycosides for PTC suppression therapy, Medchemcomm, 5, 1092-1105, doi: 10.1039/ C4MD00081A.

119. Bidou, L., Bugaud, O., Belakhov, V., Baasov, T., and Namy, O. (2017) Characterization of new-generation aminoglycoside promoting premature termination codon readthrough in cancer cells, RNA Biol., 14, 378-388, doi: 10.1080/15476286.2017.1285480.

120. Mattis, V. B., Rai, R., Wang, J., Chang, C. W., Coady, T., and Lorson, C. L. (2006) Novel aminoglycosides increase SMN levels in spinal muscular atrophy fibroblasts, Hum. Genet., 120, 589-601, doi: 10.1007/s00439-006-0245-7.

121. Baradaran-Heravi, A., Niesser, J., Balgi, A. D., Choi, K., Zimmerman, C., et al. (2017) Gentamicin B1 is a minor gentamicin component with major nonsense mutation suppression activity, Proc. Natl. Acad. Sci. USA, 114, 34793484, doi: 10.1073/pnas.1620982114.

122. Fan-Minogue, H., and Bedwell, D. M. (2008) Eukaryotic ribosomal RNA determinants of aminoglycoside resistance 
and their role in translational fidelity, $R N A, \mathbf{1 4}, 148-157$, doi: $10.1261 /$ rna.805208.

123. Recht, M. I., Douthwaite, S., and Puglisi, J. D. (1999) Basis for prokaryotic specificity of action of aminoglycoside antibiotics, EMBO J., 18, 3133-3138, doi: 10.1093/ emboj/18.11.3133.

124. Wargo, K. A., and Edwards, J. D. (2014) Aminoglycosideinduced nephrotoxicity, J. Pharm. Pract., 27, 573-577, doi: $10.1177 / 0897190014546836$.

125. Nguyen, T., and Jeyakumar, A. (2019) Genetic susceptibility to aminoglycoside ototoxicity, Int. J. Pediatr. Otorhinolaryngol., 120, 15-19, doi: 10.1016/j.ijporl.2019. 02.002 .

126. Aviner, R. (2020) The science of puromycin: from studies of ribosome function to applications in biotechnology, Comput. Struct. Biotechnol. J., 18, 1074-1083, doi: 10.1016/ j.csbj.2020.04.014.

127. Fritsch, C., Herrmann, A., Nothnagel, M., Szafranski, K., Huse, K., et al. (2012) Genome-wide search for novel human uORFs and $\mathrm{N}$-terminal protein extensions using ribosomal footprinting, Genome Res., 22, 2208-2218, doi: 10.1101/gr.139568.112.

128. Hobson, B. D., Kong, L., Hartwick, E. W., Gonzalez Jr., R. L., and Sims, P. A. (2020) Elongation inhibitors do not prevent the release of puromycylated nascent polypeptide chains from ribosomes, BioRxiv, doi: 10.1101/2020.06. 15.152488 .

129. Enam, S. U., Zinshteyn, B., Goldman, D. H., Cassani, M., Livingston, N. M., Seydoux, G., and Green, R. (2020) Puromycin reactivity does not accurately localize translation at the subcellular level, BioRxiv, doi: 10.1101/ 2020.06.22.165217.

130. Wong, W., Bai, X. C., Sleebs, B. E., Triglia, T., Brown, A., et al. (2017) Mefloquine targets the Plasmodium falciparum 80 S ribosome to inhibit protein synthesis, Nat. Microbiol., 2, 17031, doi: 10.1038/nmicrobiol.2017.31.

131. Shi, W. W., Mak, A. N., Wong, K. B., and Shaw, P. C. (2016) Structures and ribosomal interaction of ribosomeinactivating proteins, Molecules, 21, 1588, doi: 10.3390/ molecules21111588.

132. Olombrada, M., Lazaro-Gorines, R., Lopez-Rodriguez, J. C., Martinez-Del-Pozo, A., Onaderra, M., et al. (2017) Fungal ribotoxins: a review of potential biotechnological applications, Toxins, 9, 71, doi: 10.3390/toxins9020071.

133. Kozak, M., and Shatkin, A. J. (1978) Migration of $40 \mathrm{~S}$ ribosomal subunits on messenger RNA in the presence of edeine, J. Biol. Chem., 253, 6568-6577.

134. Vassilenko, K. S., Alekhina, O. M., Dmitriev, S. E., Shatsky, I. N., and Spirin, A. S. (2011) Unidirectional constant rate motion of the ribosomal scanning particle during eukaryotic translation initiation, Nucleic Acids Res., 39, 5555-5567, doi: 10.1093/nar/gkr147.

135. Kozak, M. (2007) Some thoughts about translational regulation: forward and backward glances, J. Cell. Biochem., 102, 280-290, doi: 10.1002/jcb.21464.

136. Contreras, A., and Carrasco, L. (1979) Selective inhibition of protein synthesis in virus-infected mammalian cells, J. Virol., 29, 114-122, doi: 10.1128/JVI.29.1.114-122.1979.

137. Baxter, R., Knell, V. C., Somerville, H. J., Swain, H. M., and Weeks, D. P. (1973) Effect of MDMP on protein synthesis in wheat and bacteria, Nat. New Biol., 243, 139-142, doi: $10.1038 /$ newbio243139a0.
138. Mokas, S., Mills, J. R., Garreau, C., Fournier, M. J., Robert, F., Arya, P., Kaufman, R. J., Pelletier, J., and Mazroui, R. (2009) Uncoupling stress granule assembly and translation initiation inhibition, Mol. Biol. Cell, 20, 2673-2683, doi: 10.1091/mbc.E08-10-1061.

139. Weeks, D. P., and Baxter, R. (1972) Specific inhibition of peptide-chain initiation by 2-(4-methyl-2,6-dinitroanilino)-N-methylpropionamide, Biochemistry, 11, 30603064, doi: 10.1021/bi00766a018.

140. Baxter, R., and McGowan, J. E. (1976) MDMP action: degradative effects on polyribosomes from wheat roots and the inhibition of protein initiation, J. Exp. Bot., 27, 525531, doi: 10.1093/jxb/27.3.525.

141. Gritz, L. R., Mitlin, J. A., Cannon, M., Littlewood, B., Carter, C. J., and Davies, J. E. (1982) Ribosome structure, maturation of ribosomal RNA and drug sensitivity in temperature-sensitive mutants of Saccharomyces cerevisiae, Mol. Gen. Genet., 188, 384-391, doi: 10.1007/BF00330038.

142. Pesce, E., Miluzio, A., Turcano, L., Minici, C., Cirino, D., et al. (2020) Discovery and preliminary characterization of translational modulators that impair the binding of eIF6 to 60S ribosomal subunits, Cells, 9, doi: 10.3390/ cells9010172.

143. Brina, D., Miluzio, A., Ricciardi, S., and Biffo, S. (2015) eIF6 anti-association activity is required for ribosome biogenesis, translational control and tumor progression, Biochim. Biophys. Acta, 1849, 830-835, doi: 10.1016/j.bbagrm.2014.09.010.

144. Florin, T., Maracci, C., Graf, M., Karki, P., Klepacki, D., et al. (2017) An antimicrobial peptide that inhibits translation by trapping release factors on the ribosome, Nat. Struct. Mol. Biol., 24, 752-757, doi: 10.1038/nsmb.3439.

145. Colson, G., Rabault, B., Lavelle, F., and Zerial, A. (1992) Mode of action of the antitumor compound girodazole (RP 49532A, NSC 627434), Biochem. Pharmacol., 43, 1717-1723, doi: 10.1016/0006-2952(92)90701-j.

146. Lavelle, F., Zerial, A., Fizames, C., Rabault, B., and Curaudeau, A. (1991) Antitumor activity and mechanism of action of the marine compound girodazole, Invest. New Drugs, 9, 233-244, doi: 10.1007/bf00176976.

147. Catimel, G., Coquard, R., Guastalla, J. P., Merrouche, Y., Le Bail, N., Alakl, M. K., Dumortier, A., Foy, M., and Clavel, M. (1995) Phase I study of RP 49532A, a new protein-synthesis inhibitor, in patients with advanced refractory solid tumors, Cancer Chemother. Pharmacol., 35, 246248, doi: 10.1007/BF00686555.

148. Bordeira-Carrico, R., Pego, A. P., Santos, M., and Oliveira, C. (2012) Cancer syndromes and therapy by stopcodon readthrough, Trends Mol. Med., 18, 667-678, doi: 10.1016/j.molmed.2012.09.004.

149. Mort, M., Ivanov, D., Cooper, D. N., and Chuzhanova, N. A. (2008) A meta-analysis of nonsense mutations causing human genetic disease, Hum. Mut., 29, 1037-1047, doi: 10.1002/humu.20763.

150. Keeling, K. M., Xue, X., Gunn, G., and Bedwell, D. M. (2014) Therapeutics based on stop codon readthrough, Annu. Rev. Genomics Hum. Genet., 15, 371-394, doi: 10.1146/annurev-genom-091212-153527.

151. Lee, H. L., and Dougherty, J. P. (2012) Pharmaceutical therapies to recode nonsense mutations in inherited diseases, Pharmacol. Ther., 136, 227-266, doi: 10.1016/ j.pharmthera.2012.07.007. 
152. Ng, M. Y., Zhang, H., Weil, A., Singh, V., Jamiolkowski, R., et al. (2018) New in vitro assay measuring direct interaction of nonsense suppressors with the eukaryotic protein synthesis machinery, ACS Med. Chem. Lett., 9, 1285-1291, doi: 10.1021/acsmedchemlett.8b00472.

153. Floquet, C., Rousset, J. P., and Bidou, L. (2011) Readthrough of premature termination codons in the adenomatous polyposis coli gene restores its biological activity in human cancer cells, PLoS One, 6, e24125, doi: 10.1371/journal.pone.0024125.

154. Prayle, A., and Smyth, A. R. (2010) Aminoglycoside use in cystic fibrosis: therapeutic strategies and toxicity, Curr. Opin. Pulm. Med., 16, 604-610, doi: 10.1097/MCP. 0b013e32833eebfd.

155. Zingman, L. V., Park, S., Olson, T. M., Alekseev, A. E., and Terzic, A. (2007) Aminoglycoside-induced translational read-through in disease: overcoming nonsense mutations by pharmacogenetic therapy, Clin. Pharmacol. Ther., 81, 99-103, doi: 10.1038/sj.clpt.6100012.

156. Lentini, L., Melfi, R., Di Leonardo, A., Spinello, A., Barone, G., Pace, A., Palumbo Piccionello, A., and Pibiri, I. (2014) Toward a rationale for the PTC124 (Ataluren) promoted readthrough of premature stop codons: a computational approach and GFP-reporter cell-based assay, Mol. Pharm., 11, 653-664, doi: 10.1021/mp400230s.

157. Konstan, M. W., VanDevanter, D. R., Rowe, S. M., Wilschanski, M., Kerem, E., et al. (2020) Efficacy and safety of ataluren in patients with nonsense-mutation cystic fibrosis not receiving chronic inhaled aminoglycosides: the international, randomized, double-blind, placebocontrolled Ataluren Confirmatory Trial in Cystic Fibrosis (ACT CF), J. Cyst. Fibros., 19, 595-601, doi: 10.1016/ j.jcf.2020.01.007.

158. Zainal Abidin, N., Haq, I. J., Gardner, A. I., and Brodlie, M. (2017) Ataluren in cystic fibrosis: development, clinical studies and where are we now? Exp. Opin. Pharmacother., 18, 1363-1371, doi: 10.1080/14656566.2017.1359255.

159. Auld, D. S., Thorne, N., Maguire, W. F., and Inglese, J. (2009) Mechanism of PTC124 activity in cell-based luciferase assays of nonsense codon suppression, Proc. Natl. Acad. Sci. USA, 106, 3585-3590, doi: 10.1073/pnas. 0813345106.

160. Altamura, E., Borgatti, M., Finotti, A., Gasparello, J., Gambari, R., Spinelli, M., Castaldo, R., and Altamura, N. (2016) Chemical-induced read-through at premature termination codons determined by a rapid dual-fluorescence system based on S. cerevisiae, PLoS One, 11, e0154260, doi: 10.1371/journal.pone.0154260.

161. Hamada, K., Omura, N., Taguchi, A., Baradaran-Heravi, A., Kotake, M., et al. (2019) New negamycin-based potent readthrough derivative effective against TGA-type nonsense mutations, ACS Med. Chem. Lett., 10, 1450-1456, doi: 10.1021/acsmedchemlett.9b00273.

162. Arakawa, M., Shiozuka, M., Nakayama, Y., Hara, T., Hamada, M., et al. (2003) Negamycin restores dystrophin expression in skeletal and cardiac muscles of mdx mice, J. Biochem., 134, 751-758, doi: 10.1093/jb/mvg203.

163. Olivier, N. B., Altman, R. B., Noeske, J., Basarab, G. S., Code, E., et al. (2014) Negamycin induces translational stalling and miscoding by binding to the small subunit head domain of the Escherichia coli ribosome, Proc. Natl. Acad. Sci. USA, 111, 16274-16279, doi: 10.1073/pnas.1414401111.
164. Ferguson, M. W., Gerak, C. A. N., Chow, C. C. T., Rastelli, E. J., Elmore, K. E., et al. (2019) The antimalarial drug mefloquine enhances TP53 premature termination codon readthrough by aminoglycoside G418, PLoS One, 14, e0216423, doi: 10.1371/journal.pone.0216423.

165. Baradaran-Heravi, A., Balgi, A. D., Zimmerman, C., Choi, K., Shidmoossavee, F. S., et al. (2016) Novel small molecules potentiate premature termination codon readthrough by aminoglycosides, Nucleic Acids Res., 44, 6583-6598, doi: 10.1093/nar/gkw638.

166. Nurenberg-Goloub, E., and Tampe, R. (2019) Ribosome recycling in mRNA translation, quality control, and homeostasis, Biol. Chem., 401, 47-61, doi: 10.1515/hsz2019-0279.

167. Buskirk, A. R., and Green, R. (2017) Ribosome pausing, arrest and rescue in bacteria and eukaryotes, Philos. Trans. R. Soc. Lond. B Biol. Sci., 372, 20160183, doi: 10.1098/ rstb.2016.0183.

168. Hirokawa, G., Kiel, M. C., Muto, A., Selmer, M., Raj, V. S., Liljas, A., Igarashi, K., Kaji, H., and Kaji, A. (2002) Post-termination complex disassembly by ribosome recycling factor, a functional tRNA mimic, EMBO J., 21, 2272-2281, doi: 10.1093/emboj/21.9.2272.

169. Kurata, S., Shen, B., Liu, J. O., Takeuchi, N., Kaji, A., and Kaji, H. (2013) Possible steps of complete disassembly of post-termination complex by yeast eEF3 deduced from inhibition by translocation inhibitors, Nucleic Acids Res., 41, 264-276, doi: 10.1093/nar/gks958.

170. Kurata, S., Nielsen, K. H., Mitchell, S. F., Lorsch, J. R., Kaji, A., and Kaji, H. (2010) Ribosome recycling step in yeast cytoplasmic protein synthesis is catalyzed by eEF3 and ATP, Proc. Natl. Acad. Sci. USA, 107, 10854-10859, doi: $10.1073 /$ pnas. 1006247107 .

171. Borg, A., Pavlov, M., and Ehrenberg, M. (2016) Mechanism of fusidic acid inhibition of RRF- and EF-Gdependent splitting of the bacterial post-termination ribosome, Nucleic Acids Res., 44, 3264-3275, doi: 10.1093/ nar/gkw178.

172. Sanchez-Murcia, P. A., Cortes-Cabrera, A., and Gago, F. (2017) Structural rationale for the cross-resistance of tumor cells bearing the A399V variant of elongation factor eEF1A1 to the structurally unrelated didemnin B, ternatin, nannocystin A and ansatrienin B, J. Comput. Aided Mol. Des., 31, 915-928, doi: 10.1007/s10822-017-0066-x.

173. Carelli, J. D., Sethofer, S. G., Smith, G. A., Miller, H. R., Simard, J. L., Merrick, W. C., Jain, R. K., Ross, N. T., and Taunton, J. (2015) Ternatin and improved synthetic variants kill cancer cells by targeting the elongation factor-1A ternary complex, eLife, 4, doi: 10.7554/eLife.10222.

174. Lee, J., Currano, J. N., Carroll, P. J., and Joullie, M. M. (2012) Didemnins, tamandarins and related natural products, Nat. Prod. Rep., 29, 404-424, doi: 10.1039/ c2np00065b.

175. SirDeshpande, B. V., and Toogood, P. L. (1995) Mechanism of protein synthesis inhibition by didemnin B in vitro, Biochemistry, 34, 9177-9184, doi: 10.1021/ bi00028a030.

176. Shao, S., Murray, J., Brown, A., Taunton, J., Ramakrishnan, V., and Hegde, R. S. (2016) Decoding mammalian ribosome-mRNA states by translational GTPase complexes, Cell, 167, 1229-1240 e1215, doi: $10.1016 /$ j.cell.2016.10.046. 
177. Losada, A., Munoz-Alonso, M. J., Garcia, C., SanchezMurcia, P. A., Martinez-Leal, J. F., et al. (2016) Translation elongation factor eEF1A2 is a novel anticancer target for the marine natural product plitidepsin, Sci. Rep., 6, 35100, doi: 10.1038/srep35100.

178. Adrio, J., Cuevas, C., Manzanares, I., and Joullie, M. M. (2007) Total synthesis and biological evaluation of tamandarin B analogues, J. Org. Chem., 72, 5129-5138, doi: 10.1021/jo070412r.

179. Lindqvist, L., Robert, F., Merrick, W., Kakeya, H., Fraser, C., Osada, H., and Pelletier, J. (2010) Inhibition of translation by cytotrienin $\mathrm{A}-\mathrm{a}$ member of the ansamycin family, $R N A$, 16, 2404-2413, doi: 10.1261/rna.2307710.

180. Yamada, Y., Tashiro, E., Taketani, S., Imoto, M., and Kataoka, T. (2011) Mycotrienin II, a translation inhibitor that prevents ICAM-1 expression induced by pro-inflammatory cytokines, J. Antibiot. (Tokyo), 64, 361-366, doi: $10.1038 /$ ja.2011.23.

181. Krastel, P., Roggo, S., Schirle, M., Ross, N. T., Perruccio, F., et al. (2015) Nannocystin A: an elongation factor 1 inhibitor from Myxobacteria with differential anti-cancer properties, Angew. Chem. Int. Ed. Engl., 54, 10149-10154, doi: 10.1002/anie.201505069.

182. Justice, M. C., Hsu, M. J., Tse, B., Ku, T., Balkovec, J., Schmatz, D., and Nielsen, J. (1998) Elongation factor 2 as a novel target for selective inhibition of fungal protein synthesis, J. Biol. Chem., 273, 3148-3151, doi: 10.1074/ jbc.273.6.3148.

183. Dominguez, J. M., Kelly, V. A., Kinsman, O. S., Marriott, M. S., Gomez de las Heras, F., and Martin, J. J. (1998) Sordarins: a new class of antifungals with selective inhibition of the protein synthesis elongation cycle in yeasts, Antimicrob. Agents Chemother., 42, 2274-2278, doi: 10.1128/AAC.42.9.2274.

184. Basilio, A., Justice, M., Harris, G., Bills, G., Collado, J., et al. (2006) The discovery of moriniafungin, a novel sordarin derivative produced by Morinia pestalozzioides, Bioorg. Med. Chem., 14, 560-566, doi: 10.1016/j.bmc. 2005.08.046.

185. Herreros, E., Almela, M. J., Lozano, S., Gomez de las Heras, F., and Gargallo-Viola, D. (2001) Antifungal activities and cytotoxicity studies of six new azasordarins, Antimicrob. Agents Chemother., 45, 3132-3139, doi: 10.1128/AAC.45.11.3132-3139.2001.

186. Jorgensen, R., Ortiz, P. A., Carr-Schmid, A., Nissen, P., Kinzy, T. G., and Andersen, G. R. (2003) Two crystal structures demonstrate large conformational changes in the eukaryotic ribosomal translocase, Nat. Struct. Biol., 10, 379-385, doi: 10.1038/nsb923.

187. Soe, R., Mosley, R. T., Justice, M., Nielsen-Kahn, J., Shastry, M., Merrill, A. R., and Andersen, G. R. (2007) Sordarin derivatives induce a novel conformation of the yeast ribosome translocation factor eEF2, J. Biol. Chem., 282, 657-666, doi: 10.1074/jbc.M607830200.

188. Spahn, C. M., Gomez-Lorenzo, M. G., Grassucci, R. A., Jorgensen, R., Andersen, G. R., et al. (2004) Domain movements of elongation factor eEF2 and the eukaryotic $80 \mathrm{~S}$ ribosome facilitate tRNA translocation, EMBO J., 23, 1008-1019, doi: 10.1038/sj.emboj.7600102.

189. Malkin, M., and Lipmann, F. (1969) Fusidic acid: inhibition of factor T2 in reticulocyte protein synthesis, Science, 164, 71-72, doi: 10.1126/science.164.3875.71.
190. Botet, J., Rodriguez-Mateos, M., Ballesta, J. P., Revuelta, J. L., and Remacha, M. (2008) A chemical genomic screen in Saccharomyces cerevisiae reveals a role for diphthamidation of translation elongation factor 2 in inhibition of protein synthesis by sordarin, Antimicrob. Agents Chemother., 52, 1623-1629, doi: 10.1128/AAC.01603-07.

191. Yates, S. P., Jorgensen, R., Andersen, G. R., and Merrill, A. R. (2006) Stealth and mimicry by deadly bacterial toxins, Trends Biochem. Sci., 31, 123-133, doi: 10.1016/ j.tibs.2005.12.007.

192. Stickel, S. A., Gomes, N. P., Frederick, B., Raben, D., and $\mathrm{Su}$, T. T. (2015) Bouvardin is a radiation modulator with a novel mechanism of action, Radiat. Res., 184, 392403, doi: 10.1667/RR14068.1.

193. Zalacain, M., Zaera, E., Vazquez, D., and Jimenez, A. (1982) The mode of action of the antitumor drug bouvardin, an inhibitor of protein synthesis in eukaryotic cells, FEBS Lett., 148, 95-97, doi: 10.1016/0014-5793(82)81250-7.

194. Rambelli, F., Brigotti, M., Zamboni, M., Denaro, M., Montanaro, L., and Sperti, S. (1989) Effect of the antibiotic purpuromycin on cell-free protein-synthesizing systems, Biochem. J., 259, 307-310, doi: 10.1042/ bj2590307.

195. Baragana, B., Hallyburton, I., Lee, M. C., Norcross, N. R., Grimaldi, R., et al. (2015) A novel multiple-stage antimalarial agent that inhibits protein synthesis, Nature, 522, 315-320, doi: 10.1038/nature14451.

196. Turpaev, K. T. (2018) Translation factor eIF5A, modification with hypusine and role in regulation of gene expression. eIF5A as a target for pharmacological interventions, Biochemistry (Moscow), 83, 863-873, doi: 10.1134/ S0006297918080011.

197. Dong, Z., and Zhang, J. T. (2003) EIF3 p170, a mediator of mimosine effect on protein synthesis and cell cycle progression, Mol. Biol. Cell, 14, 3942-3951, doi: 10.1091/ mbc.e02-12-0784.

198. Moerke, N. J., Aktas, H., Chen, H., Cantel, S., Reibarkh, M. Y., et al. (2007) Small-molecule inhibition of the interaction between the translation initiation factors eIF4E and eIF4G, Cell, 128, 257-267, doi: 10.1016/j.cell.2006. 11.046.

199. Sekiyama, N., Arthanari, H., Papadopoulos, E., Rodriguez-Mias, R. A., Wagner, G., and Leger-Abraham, M. (2015) Molecular mechanism of the dual activity of 4EGI-1: dissociating eIF4G from eIF4E but stabilizing the binding of unphosphorylated 4E-BP1, Proc. Natl. Acad. Sci. USA, 112, E4036-E4045, doi: 10.1073/pnas. 1512118112.

200. Papadopoulos, E., Jenni, S., Kabha, E., Takrouri, K. J., Yi, T., et al. (2014) Structure of the eukaryotic translation initiation factor eIF4E in complex with 4EGI-1 reveals an allosteric mechanism for dissociating eIF4G, Proc. Natl. Acad. Sci. USA, 111, E3187-3195, doi: 10.1073/pnas. 1410250111.

201. Shatsky, I. N., Dmitriev, S. E., Andreev, D. E., and Terenin, I. M. (2014) Transcriptome-wide studies uncover the diversity of modes of mRNA recruitment to eukaryotic ribosomes, Crit. Rev. Biochem. Mol. Biol., 49, 164-177, doi: 10.3109/10409238.2014.887051.

202. Cencic, R., Hall, D. R., Robert, F., Du, Y., Min, J., et al. (2011) Reversing chemoresistance by small molecule inhibition of the translation initiation complex eIF4F, Proc. 
Natl. Acad. Sci. USA, 108, 1046-1051, doi: 10.1073/pnas. 1011477108.

203. Cencic, R., Desforges, M., Hall, D. R., Kozakov, D., Du, Y., et al. (2011) Blocking eIF4E-eIF4G interaction as a strategy to impair coronavirus replication, J. Virol., 85, 6381-6389, doi: 10.1128/JVI.00078-11.

204. Cao, J., He, L., Lin, G., Hu, C., Dong, R., et al. (2014) Cap-dependent translation initiation factor, eIF4E, is the target for Ouabain-mediated inhibition of HIF-1alpha, Biochem. Pharmacol., 89, 20-30, doi: 10.1016/j.bcp. 2013.12.002.

205. Huang, C. T., Hsieh, C. H., Oyang, Y. J., Huang, H. C., and Juan, H. F. (2018) A large-scale gene expression intensity-based similarity metric ford repositioning, iScience, 7, 40-52, doi: 10.1016/j.isci.2018.08.017.

206. Perne, A., Muellner, M. K., Steinrueck, M., CraigMueller, N., Mayerhofer, J., et al. (2009) Cardiac glycosides induce cell death in human cells by inhibiting general protein synthesis, PLoS One, 4, e8292, doi: 10.1371/ journal.pone.0008292.

207. Hossan, M. S., Chan, Z. Y., Collins, H. M., Shipton, F. N., Butler, M. S., et al. (2019) Cardiac glycoside cerberin exerts anticancer activity through PI3K/AKT/mTOR signal transduction inhibition, Cancer Lett., 453, 57-73, doi: 10.1016/j.canlet.2019.03.034.

208. Howard, C. M., Estrada, M., Terrero, D., Tiwari, A. K., and Raman, D. (2020) Identification of cardiac glycosides as novel inhibitors of eIF4A1-mediated translation in triple-negative breast cancer cells, Cancers, 12, doi: $10.3390 /$ cancers 12082169 .

209. Kentsis, A., Topisirovic, I., Culjkovic, B., Shao, L., and Borden, K. L. (2004) Ribavirin suppresses eIF4E-mediated oncogenic transformation by physical mimicry of the 7methyl guanosine mRNA cap, Proc. Natl. Acad. Sci. USA, 101, 18105-18110, doi: 10.1073/pnas.0406927102.

210. Westman, B., Beeren, L., Grudzien, E., Stepinski, J., Worch, R., et al. (2005) The antiviral drug ribavirin does not mimic the 7-methylguanosine moiety of the mRNA cap structure in vitro, $R N A, \mathbf{1 1}, 1505-1513$, doi: 10.1261/ rna.2132505.

211. Yan, Y., Svitkin, Y., Lee, J. M., Bisaillon, M., and Pelletier, J. (2005) Ribavirin is not a functional mimic of the 7-methyl guanosine mRNA cap, $R N A, \mathbf{1 1}, 1238-1244$, doi: 10.1261/rna.2930805.

212. Kentsis, A., Volpon, L., Topisirovic, I., Soll, C. E., Culjkovic, B., Shao, L., and Borden, K. L. (2005) Further evidence that ribavirin interacts with eIF4E, RNA, 11, 1762-1766, doi: 10.1261/rna.2238705.

213. Tan, K., Culjkovic, B., Amri, A., and Borden, K. L. (2008) Ribavirin targets eIF4E dependent Akt survival signaling, Biochem. Biophys. Res. Commun., 375, 341-345, doi: 10.1016/j.bbrc.2008.07.163.

214. Chu, J., and Pelletier, J. (2015) Targeting the eIF4A RNA helicase as an anti-neoplastic approach, Biochim. Biophys. Acta, 1849, 781-791, doi: 10.1016/j.bbagrm.2014.09.006.

215. Naineni, S. K., Itoua Maiga, R., Cencic, R., Putnam, A. A., Amador, L. A., Rodriguez, A. D., Jankowsky, E., and Pelletier, J. (2020) A comparative study of small molecules targeting eIF4A, RNA, 26, 541-549, doi: 10.1261/ rna.072884.119.

216. Cencic, R., and Pelletier, J. (2016) Hippuristanol - a potent steroid inhibitor of eukaryotic initiation factor $4 \mathrm{~A}$,
Translation, 4, e1137381, doi: 10.1080/21690731.2015. 1137381.

217. Bordeleau, M. E., Matthews, J., Wojnar, J. M., Lindqvist, L., Novac, O., et al. (2005) Stimulation of mammalian translation initiation factor eIF4A activity by a small molecule inhibitor of eukaryotic translation, Proc. Natl. Acad. Sci. USA, 102, 10460-10465, doi: 10.1073/pnas.0504249102.

218. Low, W. K., Dang, Y., Schneider-Poetsch, T., Shi, Z., Choi, N. S., Merrick, W. C., Romo, D., and Liu, J. O. (2005) Inhibition of eukaryotic translation initiation by the marine natural product pateamine A, Mol. Cell, 20, 709722, doi: 10.1016/j.molcel.2005.10.008.

219. Iwasaki, S., Iwasaki, W., Takahashi, M., Sakamoto, A., Watanabe, C., et al. (2019) The Translation inhibitor rocaglamide targets a bimolecular cavity between eIF4A and polypurine RNA, Mol. Cell, 73, 738-748 e739, doi: 10.1016/j.molcel.2018.11.026.

220. Cencic, R., Carrier, M., Galicia-Vazquez, G., Bordeleau, M. E., Sukarieh, R., et al. (2009) Antitumor activity and mechanism of action of the cyclopenta[b]benzofuran, silvestrol, PLoS One, 4, e5223, doi: 10.1371/journal.pone. 0005223.

221. Chu, J., Zhang, W., Cencic, R., O'Connor, P. B. F., Robert, F., et al. (2020) Rocaglates induce gain-of-function alterations to eIF4A and eIF4F, Cell Rep., 30, 24812488 e2485, doi: 10.1016/j.celrep.2020.02.002.

222. Low, W. K., Li, J., Zhu, M., Kommaraju, S. S., ShahMittal, J., Hull, K., Liu, J. O., and Romo, D. (2014) Second-generation derivatives of the eukaryotic translation initiation inhibitor pateamine A targeting eIF4A as potential anticancer agents, Bioorg. Med. Chem., 22, 116125, doi: 10.1016/j.bmc.2013.11.046.

223. Tillotson, J., Kedzior, M., Guimaraes, L., Ross, A. B., Peters, T. L., et al. (2017) ATP-competitive, marine derived natural products that target the DEAD box helicase, eIF4A, Bioorg. Med. Chem. Lett., 27, 4082-4085, doi: 10.1016/j.bmcl.2017.07.045.

224. Stewart, M. L., Grollman, A. P., and Huang, M. T. (1971) Aurintricarboxylic acid: inhibitor of initiation of protein synthesis, Proc. Natl. Acad. Sci. USA, 68, 97-101, doi: 10.1073/pnas.68.1.97.

225. Huang, M. T., and Grollman, A. P. (1973) Pyrocatechol violet: an inhibitor of initiation of protein synthesis, Biochem. Biophys. Res. Commun., 53, 1049-1059, doi: 10.1016/0006-291x(73)90571-8.

226. Gonzalez, R. G., Blackburn, B. J., and Schleich, T. (1979) Fractionation and structural elucidation of the active components of aurintricarboxylic acid, a potent inhibitor of protein nucleic acid interactions, Biochim. Biophys. Acta, 562, 534-545, doi: 10.1016/0005-2787(79)90116-3.

227. Liao, L. L., Horwitz, S. B., Huang, M. T., Grollman, A. P., Steward, D., and Martin, J. (1975) Triphenylmethane dyes as inhibitors of reverse transcriptase, ribonucleic acid polymerase, and protein synthesis. Structure-activity relationships, J. Med. Chem., 18, 117-120, doi: 10.1021/ jm00235a029.

228. Leader, D. P. (1972) Aurintricarboxylic acid inhibition of the binding of phenylalanyl-tRNAa to rat liver ribosomal subunits, FEBS Lett., 22, 245-248, doi: 10.1016/00145793(72)80055-3.

229. Contreras, A., Vazquez, D., and Carrasco, L. (1978) Inhibition, by selected antibiotics, of protein synthesis in 
cells growing in tissue cultures, J. Antibiot. (Tokyo), 31, 598-602, doi: 10.7164/antibiotics.31.598.

230. Novac, O., Guenier, A. S., and Pelletier, J. (2004) Inhibitors of protein synthesis identified by a high throughput multiplexed translation screen, Nucleic Acids Res., 32, 902-915, doi: 10.1093/nar/gkh235.

231. Terenin, I. M., Dmitriev, S. E., Andreev, D. E., and Shatsky, I. N. (2008) Eukaryotic translation initiation machinery can operate in a bacterial-like mode without eIF2, Nat. Struct. Mol. Biol., 15, 836-841, doi: 10.1038/ nsmb. 1445.

232. Robert, F., Kapp, L. D., Khan, S. N., Acker, M. G., Kolitz, S., et al. (2006) Initiation of protein synthesis by hepatitis $\mathrm{C}$ virus is refractory to reduced eIF2.GTP.MettRNA(i)(Met) ternary complex availability, Mol. Biol. Cell, 17, 4632-4644, doi: 10.1091/mbc.e06-06-0478.

233. Carvalho, A., Chu, J., Meinguet, C., Kiss, R., Vandenbussche, G., Masereel, B., Wouters, J., Kornienko, A., Pelletier, J., and Mathieu, V. (2017) A harmine-derived beta-carboline displays anti-cancer effects in vitro by targeting protein synthesis, Eur. J. Pharmacol., 805, 25-35, doi: 10.1016/j.ejphar.2017.03.034.

234. Lee, J., Kang, S. U., Kang, M. K., Chun, M. W., Jo, Y. J., Kwak, J. H., and Kim, S. (1999) Methionyl adenylate analogues as inhibitors of methionyl-tRNA synthetase, Bioorg. Med. Chem. Lett., 9, 1365-1370, doi: 10.1016/ s0960-894x(99)00206-1.

235. Lee, J., Kang, M. K., Chun, M. W., Jo, Y. J., Kwak, J. H., and Kim, S. (1998) Methionine analogues as inhibitors of methionyl-tRNA synthetase, Bioorg. Med. Chem. Lett., 8, 3511-3514, doi: 10.1016/s0960-894x(98)00642-8.

236. Nevinsky, G. A., Favorova, O. O., Lavrik, O. I., Petrova, T. D., Kochkina, L. L., and Savchenko, T. I. (1974) Fluorinated tryptophans as substrates and inhibitors of the ATP-(32P)PPi exchange reaction catalysed by tryptophanyl tRNA synthetase, FEBS Lett., 43, 135-138, doi: 10.1016/0014-5793(74)80985-3.

237. Zhao, Y., Meng, Q., Bai, L., and Zhou, H. (2014) In silico discovery of aminoacyl-tRNA synthetase inhibitors, Int. J. Mol. Sci., 15, 1358-1373, doi: 10.3390/ijms15011358.

238. Lux, M. C., Standke, L. C., and Tan, D. S. (2019) Targeting adenylate-forming enzymes with designed sulfonyladenosine inhibitors, J. Antibiot. (Tokyo), 72, 325349, doi: 10.1038/s41429-019-0171-2.

239. Francklyn, C. S., and Mullen, P. (2019) Progress and challenges in aminoacyl-tRNA synthetase-based therapeutics, J. Biol. Chem., 294, 5365-5385, doi: 10.1074/jbc. REV118.002956.

240. Alix, J. H. (1982) Molecular aspects of the in vivo and in vitro effects of ethionine, an analog of methionine, Microbiol. Rev., 46, 281-295.

241. Fang, P., Yu, X., Jeong, S. J., Mirando, A., Chen, K., Chen, X., Kim, S., Francklyn, C. S., and Guo, M. (2015) Structural basis for full-spectrum inhibition of translational functions on a tRNA synthetase, Nat. Commun., 6, 6402, doi: $10.1038 /$ ncomms 7402 .

242. El Khoury, A., and Atoui, A. (2010) Ochratoxin a: general overview and actual molecular status, Toxins, 2, 461-493, doi: 10.3390/toxins2040461.

243. Keller, T. L., Zocco, D., Sundrud, M. S., Hendrick, M., Edenius, M., et al. (2012) Halofuginone and other febrifugine derivatives inhibit prolyl-tRNA synthetase,
Nat. Chem. Biol., 8, 311-317, doi: 10.1038/nchembio. 790.

244. Sundrud, M. S., Koralov, S. B., Feuerer, M., Calado, D. P., Kozhaya, A. E., et al. (2009) Halofuginone inhibits TH17 cell differentiation by activating the amino acid starvation response, Science, 324, 1334-1338, doi: 10.1126/ science.1172638.

245. Sarkar, J., Mao, W., Lincecum, T. L., Jr., Alley, M. R., and Martinis, S. A. (2011) Characterization of benzoxaborolebased antifungal resistance mutations demonstrates that editing depends on electrostatic stabilization of the leucyltRNA synthetase editing cap, FEBS Lett., 585, 2986-2991, doi: 10.1016/j.febslet.2011.08.010.

246. Marjanovic, J., and Kozmin, S. A. (2007) Spirofungin A: stereoselective synthesis and inhibition of isoleucyl-tRNA synthetase, Angew. Chem. Int. Ed. Engl., 46, 8854-8857, doi: 10.1002/anie.200702440.

247. Shimizu, T., Usui, T., Machida, K., Furuya, K., Osada, H., and Nakata, T. (2002) Chemical modification of reveromycin A and its biological activities, Bioorg. Med. Chem. Lett., 12, 3363-3366, doi: 10.1016/s0960894x(02)00782-5.

248. Miyamoto, Y., Machida, K., Mizunuma, M., Emoto, Y., Sato, N., et al. (2002) Identification of Saccharomyces cerevisiae isoleucyl-tRNA synthetase as a target of the G1specific inhibitor Reveromycin A, J. Biol. Chem., 277, 28810-28814, doi: 10.1074/jbc.M203827200.

249. Woo, J. T., Kawatani, M., Kato, M., Shinki, T., Yonezawa, T., Kanoh, N., Nakagawa, H., Takami, M., Lee, K. H., Stern, P. H., Nagai, K., and Osada, H. (2006) Reveromycin A, an agent for osteoporosis, inhibits bone resorption by inducing apoptosis specifically in osteoclasts, Proc. Natl. Acad. Sci. USA, 103, 4729-4734, doi: 10.1073/pnas.0505663103.

250. Kirillov, S., Vitali, L. A., Goldstein, B. P., Monti, F., Semenkov, Y., Makhno, V., Ripa, S., Pon, C. L., and Gualerzi, C. O. (1997) Purpuromycin: an antibiotic inhibiting tRNA aminoacylation, $R N A, 3$, 905-913.

251. Van de Vijver, P., Ostrowski, T., Sproat, B., Goebels, J., Rutgeerts, O., Van Aerschot, A., Waer, M., and Herdewijn, P. (2008) Aminoacyl-tRNA synthetase inhibitors as potent and synergistic immunosuppressants, J. Med. Chem., 51, 3020-3029, doi: 10.1021/jm8000746.

252. Kim, Y., Sundrud, M. S., Zhou, C., Edenius, M., Zocco, D., et al. (2020) Aminoacyl-tRNA synthetase inhibition activates a pathway that branches from the canonical amino acid response in mammalian cells, Proc. Natl. Acad. Sci. USA, 117, 8900-8911, doi: 10.1073/pnas.1913788117.

253. Proud, C. G. (2019) Phosphorylation and signal transduction pathways in translational control, Cold Spring Harb. Perspect. Biol., 11, a033050, doi: 10.1101/cshperspect. a033050.

254. Roux, P. P., and Topisirovic, I. (2012) Regulation of mRNA translation by signaling pathways, Cold Spring Harb. Perspect. Biol., 4, a012252, doi: 10.1101/cshperspect. a012252.

255. Thoreen, C. C. (2017) The molecular basis of mTORC1regulated translation, Biochem. Soc. Trans., 45, 213-221, doi: 10.1042/BST20160072.

256. Siddiqui, N., and Sonenberg, N. (2015) Signalling to eIF4E in cancer, Biochemical Soc. Trans., 43, 763-772, doi: 10.1042/BST20150126. 
257. Andreev, D. E., Dmitriev, S. E., Loughran, G., Terenin, I. M., Baranov, P. V., and Shatsky, I. N. (2018) Translation control of mRNAs encoding mammalian translation initiation factors, Gene, 651, 174-182, doi: 10.1016/ j.gene.2018.02.013.

258. Cockman, E., Anderson, P., and Ivanov, P. (2020) TOP mRNPs: molecular mechanisms and principles of regulation, Biomolecules, 10, doi: 10.3390/biom 10070969.

259. Hua, H., Kong, Q., Zhang, H., Wang, J., Luo, T., and Jiang, Y. (2019) Targeting mTOR for cancer therapy, J. Hematol. Oncol., 12, 71, doi: 10.1186/s13045-019-0754-1.

260. Anisimova, A. S., Meerson, M. B., Gerashchenko, M. V., Kulakovskiy, I. V., Dmitriev, S. E., and Gladyshev, V. N. (2020) Multifaceted deregulation of gene expression and protein synthesis with age, Proc. Natl. Acad. Sci. USA, 117, 15581-15590, doi: 10.1073/pnas.2001788117.

261. Anisimova, A. S., Alexandrov, A. I., Makarova, N. E., Gladyshev, V. N., and Dmitriev, S. E. (2018) Protein synthesis and quality control in aging, Aging, 10, 4269-4288, doi: 10.18632/aging.101721.

262. Schenone, S., Brullo, C., Musumeci, F., Radi, M., and Botta, M. (2011) ATP-competitive inhibitors of mTOR: an update, Curr. Med. Chem., 18, 2995-3014, doi: 10.2174/ 092986711796391651.

263. Brunn, G. J., Williams, J., Sabers, C., Wiederrecht, G., Lawrence, J. C., Jr., and Abraham, R. T. (1996) Direct inhibition of the signaling functions of the mammalian target of rapamycin by the phosphoinositide 3-kinase inhibitors, wortmannin and LY294002, EMBO J., 15, 5256-5267.

264. Li, B. B., Qian, C., Gameiro, P. A., Liu, C. C., Jiang, T., Roberts, T. M., Struhl, K., and Zhao, J. J. (2018) Targeted profiling of RNA translation reveals mTOR-4EBP1/2independent translation regulation of mRNAs encoding ribosomal proteins, Proc. Natl. Acad. Sci. USA, 115, E9325-E9332, doi: 10.1073/pnas.1805782115.

265. Donnelly, N., Gorman, A. M., Gupta, S., and Samali, A. (2013) The eIF2alpha kinases: their structures and functions, Cell. Mol. Life Sci., 70, 3493-3511, doi: 10.1007/ s00018-012-1252-6.

266. Wek, R. C. (2018) Role of eIF2alpha kinases in translational control and adaptation to cellular stress, Cold Spring Harb. Perspect. Biol., 10, doi: 10.1101/cshperspect.a032870.

267. Akulich, K. A., Andreev, D. E., Terenin, I. M., Smirnova, V. V., Anisimova, A. S., et al. (2016) Four translation initiation pathways employed by the leaderless mRNA in eukaryotes, Sci. Rep., 6, 37905, doi: 10.1038/srep37905.

268. Joshi, M., Kulkarni, A., and Pal, J. K. (2013) Small molecule modulators of eukaryotic initiation factor 2alpha kinases, the key regulators of protein synthesis, Biochimie, 95, 1980-1990, doi: 10.1016/j.biochi.2013.07.030.

269. Chen, T., Ozel, D., Qiao, Y., Harbinski, F., Chen, L., et al. (2011) Chemical genetics identify eIF2alpha kinase hemeregulated inhibitor as an anticancer target, Nat. Chem. Biol., 7, 610-616, doi: 10.1038/nchembio.613.

270. Ganz, J., Shacham, T., Kramer, M., Shenkman, M., Eiger, H., et al. (2020) A novel specific PERK activator reduces toxicity and extends survival in Huntington's disease models, Sci. Rep., 10, 6875, doi: 10.1038/s41598020-63899-4.

271. Stockwell, S. R., Platt, G., Barrie, S. E., Zoumpoulidou, G., Te Poele, R. H., et al. (2012) Mechanism-based screen for $\mathrm{G} 1 / \mathrm{S}$ checkpoint activators identifies a selective activator of EIF2AK3/PERK signalling, PLoS One, 7, e28568, doi: $10.1371 /$ journal.pone.0028568.

272. Damgaard, C. K., and Lykke-Andersen, J. (2011) Translational coregulation of 5'TOP mRNAs by TIA-1 and TIAR, Genes Dev., 25, 2057-2068, doi: 10.1101/gad. 17355911.

273. Costa-Mattioli, M., Gobert, D., Stern, E., Gamache, K., Colina, R., et al. (2007) eIF2alpha phosphorylation bidirectionally regulates the switch from short- to long-term synaptic plasticity and memory, Cell, 129, 195-206, doi: 10.1016/j.cell.2007.01.050.

274. Boyce, M., Bryant, K. F., Jousse, C., Long, K., Harding, H. P., et al. (2005) A selective inhibitor of eIF2alpha dephosphorylation protects cells from ER stress, Science, 307, 935-939, doi: 10.1126/science.1101902.

275. Kim, S. M., Yoon, S. Y., Choi, J. E., Park, J. S., Choi, J. M., Nguyen, T., and Kim, D. H. (2010) Activation of eukaryotic initiation factor-2 alpha-kinases in okadaic acid-treated neurons, Neuroscience, 169, 1831-1839, doi: 10.1016/j.neuroscience.2010.06.016.

276. Wakula, P., Beullens, M., van Eynde, A., Ceulemans, H., Stalmans, W., and Bollen, M. (2006) The translation initiation factor eIF2beta is an interactor of protein phosphatase-1, Biochem. J., 400, 377-383, doi: 10.1042/ BJ20060758.

277. Kolupaeva, V. (2019) Serine-threonine protein phosphatases: Lost in translation, Biochim. Biophys. Acta, Mol. Cell Res., 1866, 83-89, doi: 10.1016/j.bbamcr.2018.08.006.

278. Sidrauski, C., Acosta-Alvear, D., Khoutorsky, A., Vedantham, P., Hearn, B. R., et al. (2013) Pharmacological brake-release of mRNA translation enhances cognitive memory, eLife, 2, e00498, doi: 10.7554/eLife.00498.

279. Rabouw, H. H., Langereis, M. A., Anand, A. A., Visser, L. J., de Groot, R. J., Walter, P., and van Kuppeveld, F. J. M. (2019) Small molecule ISRIB suppresses the integrated stress response within a defined window of activation, Proc. Natl. Acad. Sci. USA, 116, 2097-2102, doi: 10.1073/ pnas. 1815767116.

280. Chen, Z., Gopalakrishnan, S. M., Bui, M. H., Soni, N. B., Warrior, U., Johnson, E. F., Donnelly, J. B., and Glaser, K. B. (2011) 1-Benzyl-3-cetyl-2-methylimidazolium iodide (NH125) induces phosphorylation of eukaryotic elongation factor-2 (eEF2): a cautionary note on the anticancer mechanism of an eEF2 kinase inhibitor, J. Biol. Chem., 286, 43951-43958, doi: 10.1074/jbc.M111.301291.

281. De Gassart, A., Demaria, O., Panes, R., Zaffalon, L., Ryazanov, A. G., Gilliet, M., and Martinon, F. (2016) Pharmacological eEF2K activation promotes cell death and inhibits cancer progression, EMBO Rep., 17, 14711484, doi: 10.15252/embr.201642194.

282. Devkota, A. K., Tavares, C. D., Warthaka, M., Abramczyk, O., Marshall, K. D., Kaoud, T. S., Gorgulu, K., Ozpolat, B., and Dalby, K. N. (2012) Investigating the kinetic mechanism of inhibition of elongation factor 2 kinase by NH125: evidence of a common in vitro artifact, Biochemistry, 51, 2100-2112, doi: 10.1021/bi201787p.

283. Beretta, S., Gritti, L., Verpelli, C., and Sala, C. (2020) Eukaryotic elongation factor 2 kinase a pharmacological target to regulate protein translation dysfunction in neurological diseases, Neuroscience, 445, 42-49, doi: 10.1016/ j.neuroscience.2020.02.015. 
284. Niederberger, E., King, T. S., Russe, O. Q., and Geisslinger, G. (2015) Activation of AMPK and its impact on exercise capacity, Sports Med., 45, 1497-1509, doi: 10.1007/s40279-015-0366-z.

285. Johanns, M., Pyr Dit Ruys, S., Houddane, A., Vertommen, D., Herinckx, G., Hue, L., Proud, C. G., and Rider, M. H. (2017) Direct and indirect activation of eukaryotic elongation factor 2 kinase by AMP-activated protein kinase, Cell. Signal., 36, 212-221, doi: 10.1016/ j.cellsig.2017.05.010.

286. Sitron, C. S., and Brandman, O. (2020) Detection and degradation of stalled nascent chains via ribosome-associated quality control, Annu. Rev. Biochem., 89, 417-442, doi: 10.1146/annurev-biochem-013118-110729.

287. Iordanov, M. S., Pribnow, D., Magun, J. L., Dinh, T. H., Pearson, J. A., Chen, S. L., and Magun, B. E. (1997) Ribotoxic stress response: activation of the stress-activated protein kinase JNK1 by inhibitors of the peptidyl transferase reaction and by sequence-specific RNA damage to the alpha-sarcin/ricin loop in the 28S rRNA, Mol. Cell. Biol., 17, 3373-3381, doi: 10.1128/mcb.17.6.3373.

288. Shifrin, V. I., and Anderson, P. (1999) Trichothecene mycotoxins trigger a ribotoxic stress response that activates c-Jun $N$-terminal kinase and p38 mitogen-activated protein kinase and induces apoptosis, J. Biol. Chem., 274, 13985-13992, doi: 10.1074/jbc.274.20.13985.

289. He, K., Zhou, H. R., and Pestka, J. J. (2012) Targets and intracellular signaling mechanisms for deoxynivalenolinduced ribosomal RNA cleavage, Toxicol. Sci., 127, 382390, doi: 10.1093/toxsci/kfs 134 .

290. He, K., Zhou, H. R., and Pestka, J. J. (2012) Mechanisms for ribotoxin-induced ribosomal RNA cleavage, Toxicol. Appl. Pharmacol., 265, 10-18, doi: 10.1016/j.taap.2012. 09.017 .

291. Yang, G. H., Jarvis, B. B., Chung, Y. J., and Pestka, J. J. (2000) Apoptosis induction by the satratoxins and other trichothecene mycotoxins: relationship to ERK, p38 MAPK, and SAPK/JNK activation, Toxicol. Appl. Pharmacol., 164, 149-160, doi: 10.1006/taap.1999.8888.

292. Li, M., and Pestka, J. J. (2008) Comparative induction of $28 \mathrm{~S}$ ribosomal RNA cleavage by ricin and the trichothecenes deoxynivalenol and T-2 toxin in the macrophage, Toxicol. Sci., 105, 67-78, doi: 10.1093/toxsci/ kfn111.

293. Lee, K. H., Nishimura, S., Matsunaga, S., Fusetani, N., Ichijo, H., Horinouchi, S., and Yoshida, M. (2006) Induction of a ribotoxic stress response that stimulates stress-activated protein kinases by 13-deoxytedanolide, an antitumor marine macrolide, Biosci. Biotechnol. Biochem., 70, 161-171, doi: 10.1271/bbb.70.161.

294. Vind, A. C., Snieckute, G., Blasius, M., Tiedje, C., Krogh, N., Bekker-Jensen, D. B., et al. (2020) ZAKalpha recog- nizes stalled ribosomes through partially redundant sensor domains, Mol. Cell, 78, 700-713.e7, doi: 10.1016/j.molcel. 2020.03.021.

295. Yamada, Y., Taketani, S., Osada, H., and Kataoka, T. (2011) Cytotrienin A, a translation inhibitor that induces ectodomain shedding of TNF receptor 1 via activation of ERK and p38 MAP kinase, Eur. J. Pharmacol., 667, 113119, doi: 10.1016/j.ejphar.2011.05.072.

296. Francis, S. P., Katz, J., Fanning, K. D., Harris, K. A., Nicholas, B. D., Lacy, M., Pagana, J., Agris, P. F., and Shin, J. B. (2013) A novel role of cytosolic protein synthesis inhibition in aminoglycoside ototoxicity, J. Neurosci., 33, 3079-3093, doi: 10.1523/JNEUROSCI.3430-12.2013.

297. Jandhyala, D. M., Ahluwalia, A., Obrig, T., and Thorpe, C. M. (2008) ZAK: a MAP3Kinase that transduces Shiga toxin- and ricin-induced proinflammatory cytokine expression, Cell. Microbiol., 10, 1468-1477, doi: 10.1111/ j.1462-5822.2008.01139.x.

298. Wang, X., Mader, M. M., Toth, J. E., Yu, X., Jin, N., et al. (2005) Complete inhibition of anisomycin and UV radiation but not cytokine induced JNK and p38 activation by an aryl-substituted dihydropyrrolopyrazole quinoline and mixed lineage kinase 7 small interfering RNA, J. Biol. Chem., 280, 19298-19305, doi: 10.1074/jbc.M413059200.

299. Sauter, K. A., Magun, E. A., Iordanov, M. S., and Magun, B. E. (2010) ZAK is required for doxorubicin, a novel ribotoxic stressor, to induce SAPK activation and apoptosis in HaCaT cells, Cancer Biol. Ther., 10, 258-266, doi: $10.4161 /$ cbt.10.3.12367.

300. Wolfson, R. L., and Sabatini, D. M. (2017) The dawn of the age of amino acid sensors for the mTORC1 pathway, Cell Metab., 26, 301-309, doi 10.1016/j.cmet.2017.07.001.

301. Bhat, M., Robichaud, N., Hulea, L., Sonenberg, N., Pelletier, J., and Topisirovic, I. (2015) Targeting the translation machinery in cancer, Nat. Rev. Drug Discov., 14, 261-278, doi: 10.1038/nrd4505.

302. Gilles, A., Frechin, L., Natchiar, K., Biondani, G., Loeffelholz, O. V., et al. (2020) Targeting the human 80S ribosome in cancer: from structure to function and drug design for innovative adjuvant therapeutic strategies, Cells, 9, 629, doi: 10.3390/cells9030629.

303. Osterman, I. A., Bogdanov, A. A., Dontsova, O. A., and Sergiev, P. V. (2016) Techniques for screening translation inhibitors, Antibiotics, 5, 22, doi: 10.3390/antibiotics5030022.

304. Ivanenkov, Y. A., Zhavoronkov, A., Yamidanov, R. S., Osterman, I. A., et al. (2019) Identification of novel antibacterials using machine learning techniques, Front. Pharmacol., 10, 913, doi: 10.3389/fphar.2019.00913.

305. Blanchard, S. C., Cooperman, B. S., and Wilson, D. N. (2010) Probing translation with small-molecule inhibitors, Chem. Biol., 17, 633-645, doi: 10.1016/j.chembiol. 2010.06.003. 